July 24,2012

Mr. John Glenn

U.S. Department of Energy

Oak Ridge Office

P.O. Box 2001

Oak Ridge, TN 37831-0117

DOE CONTRACT NO. DE-AC05-06OR23100

SUBJECT: INDEPENDENT VERIFICATION OF THE CENTRAL CAMPUS AND

SOUTHEAST LAB COMPLEX BUILDING SLABS, OAK RIDGE

NATIONAL LABORATORY, OAK RIDGE, TENNESSEE

DCN: 5086-SR-03-0

Dear Mr. Glenn:

Oak Ridge Associated Universities/Oak Ridge Institute for Science and Education (ORAU/ORISE) has completed the independent verification survey of the Central Campus and Southeast Lab Complex Building Slabs. The results of this effort are provided in the enclosed report.

Please direct any additional questions you may have to me via my information below, Evan Harpenau at 865.241.8793, or Kathy Rollow at 865.574.4390.

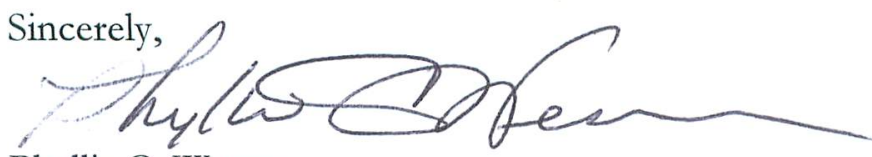

Phyllis C. Weaver

Health Physicist Project Manager

Survey Projects

PCW:fr

Enclosure

electronic cc:

L. Mezga, UT-B/ORNL

D. VanHoesen, UT-B/ORNL

S. Roberts, ORAU

T. Vitkus, ORAU

K. Rollow, ORAU

E. Bailey, ORAU

E. Harpenau, ORAU

File/5086 
INDEPENDENT VERIFICATION OF THE CENTRAL CAMPUS AND SOUTHEAST LABORATORY COMPLEX BUILDING SLABS AT OAK RIDGE NATIONAL LABORATORY, OAK RIDGE, TENNESSEE

\section{P.C. Weaver}

Prepared for the

U.S. Department of Energy

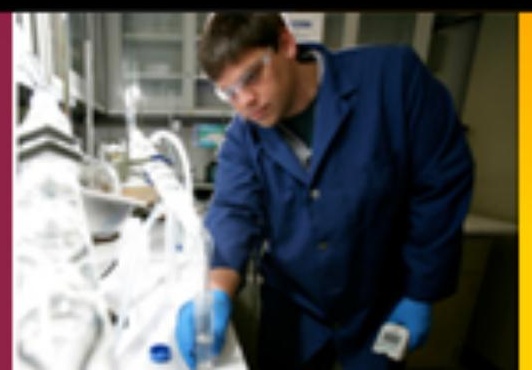

Approved for public release; further dissemination unlimited. 
The Oak Ridge Institute for Science and Education (ORISE) is a U.S. Department of Energy institute focusing on scientific initiatives to research health risks from occupational hazards, assess environmental cleanup, respond to radiation medical emergencies, support national security and emergency preparedness, and educate the next generation of scientists. ORISE is managed by Oak Ridge Associated Universities.

\section{NOTICES}

The opinions expressed herein do not necessarily reflect the opinions of the sponsoring institutions of Oak Ridge Associated Universities.

This report was prepared as an account of work sponsored by the United States Government. Neither the United States Government nor the U.S. Department of Energy, nor any of their employees, makes any warranty, expressed or implied, or assumes any legal liability or responsibility for the accuracy, completeness, or usefulness of any information, apparatus, product, or process disclosed, or represents that its use would not infringe on privately owned rights. Reference herein to any specific commercial product, process, or service by trade name, mark, manufacturer, or otherwise, does not necessarily constitute or imply its endorsement or recommendation, or favor by the U.S. Government or any agency thereof. The views and opinions of authors expressed herein do not necessarily state or reflect those of the U.S. Government or any agency thereof. 


\title{
INDEPENDENT VERIFICATION OF THE CENTRAL CAMPUS AND SOUTHEAST LABORATORY COMPLEX BUILDING SLABS AT OAK RIDGE NATIONAL LABORATORY, OAK RIDGE, TENNESSEE
}

\author{
Prepared by: \\ P. C. Weaver

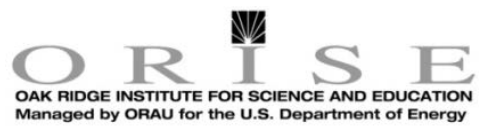 \\ Independent Environmental Assessment and Verification \\ Oak Ridge Institute for Science and Education \\ Oak Ridge, Tennessee 37831-0117 \\ Prepared for the \\ U.S. Department of Energy
}

JULY 2012

Prepared by Oak Ridge Associated Universities under the Oak Ridge Institute for Science and Education contract, number DE-AC05-06OR23100, with the U.S. Department of Energy. 


\section{INDEPENDENT VERIFICATION OF THE CENTRAL CAMPUS AND SOUTHEAST LABORATORY COMPLEX BUILDING SLABS AT OAK RIDGE NATIONAL LABORATORY, OAK RIDGE, TENNESSEE}

Prepared by:

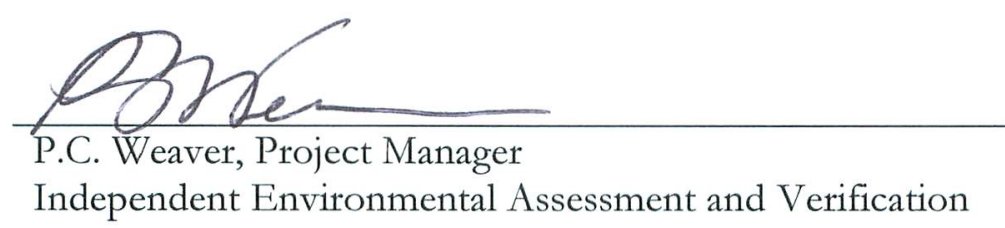

Reviewed by:

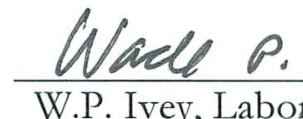

W.P. Ivey, Laboratory Group Manager

Independent Environmental Assessment and Verification

Reviewed by:

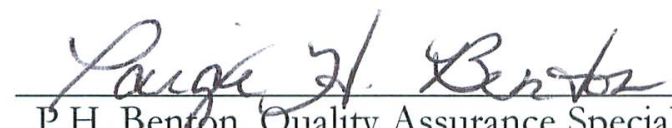

P.H. Benton, Quality Assurance Specialist

Independent Environmental Assessment and Verification

Reviewed and approved for release by:

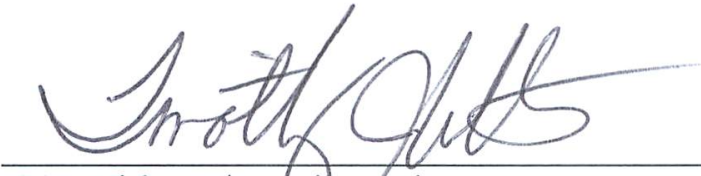

T.J. Vitkus, Associate/Director

Independent Environmental Assessment and Verification
Date: $7 / 24 / 2$

Date: $7 / 24 / 12$

Date:

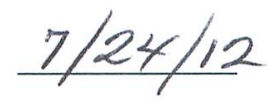

Date:

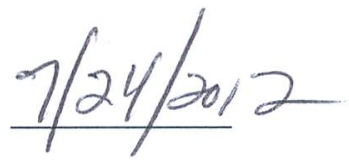

JULY 2012 


\section{CONTENTS}

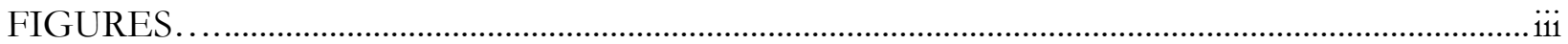

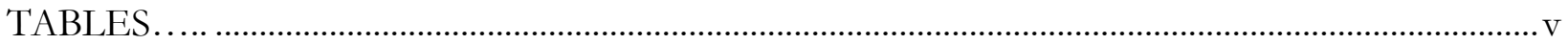

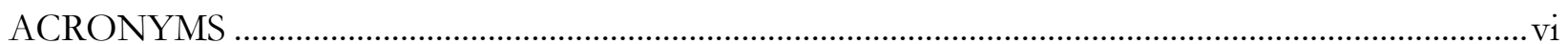

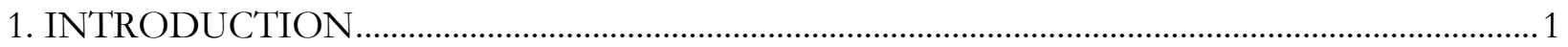

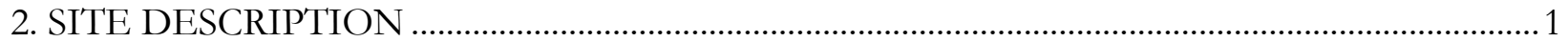

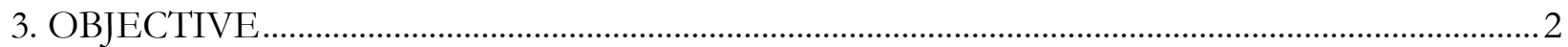

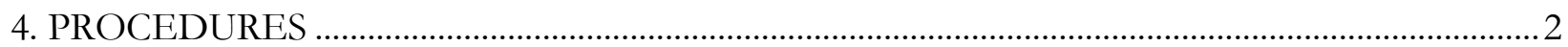

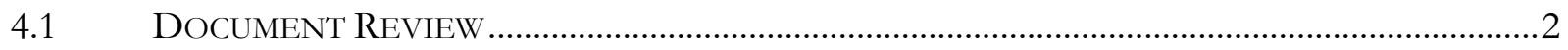

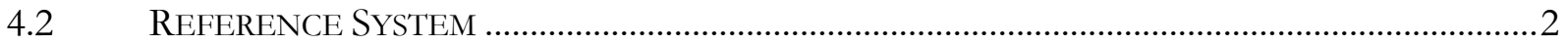

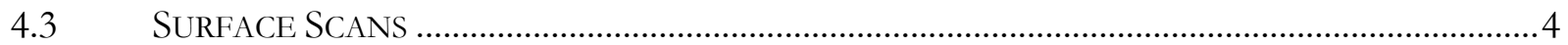

S.4 SURFACE ACTIVITY MEASUREMENTS .................................................................................

4.5 SAMPLE ANALYSIS AND DATA INTERPRETATION..................................................................

5. APPLICABLE RESIDUAL CONTAMINATION GUIDELINES …......................................... 6

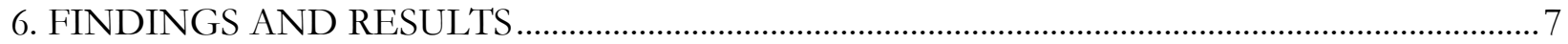

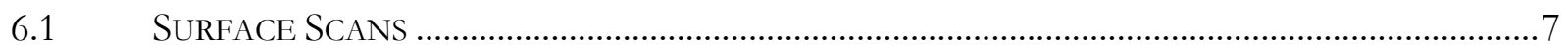

6.2 TOTAL AND REMOVABLE SURFACE ACTIVITY LEVELS............................................................

6.3 COMPARISON OF RESULTS WITH GUIDELINES ...................................................................

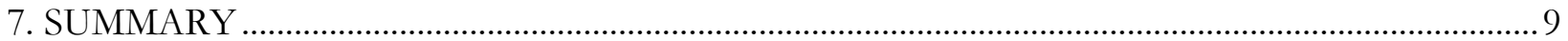

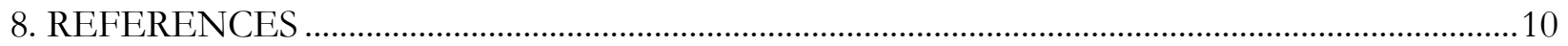

APPENDIX A: DATA PACKAGES FOR INDIVIDUAL BUILDING SLABS

APPENDIX B: MAJOR INSTRUMENTATION

APPENDIX C: SURVEY AND ANALYTICAL PROCEDURES 


\section{FIGURES}

Fig. 1. Overview of Oak Ridge National Laboratory Central Campus and Southeast Laboratory Complex....... .3

Fig. A-1. Surface Radiation Scans for the Building 3085 Slab A-2

Fig. A-2. Alpha and Alpha-plus-Beta Scans Q-Plot for the Building 3085 Slab A-3

Fig. A-3. Gamma Scan Q-Plot for the Building 3085 Slab A-4

Fig. A-4. Sampling and Direct Measurement Locations for the Building 3085 Slab A-5

Fig. A-5. Surface Radiation Scans for the Building 3098 Slab A-8

Fig. A-6. Surface Radiation Scans for the Building 3098 Remaining Walls A-9

Fig. A-7. Alpha and Alpha-Plus-Beta Scan Q-Plot for the Building 3098 Slab. A-10

Fig. A-8. Gamma Scan Q-Plot for the Building 3098 Slab.

Fig. A-9. Sampling and Direct Measurement Locations for the Building 3098 Slab. A-12

Fig. A-10. Sampling and Direct Measurement Locations for the Building 3102 Slab. A-15

Fig. A-11. Sampling and Direct Measurement Locations for the Building 3117A Slab. A-18

Fig. A-12. Surface Radiation Scans for the Building 3119 Slab A-21

Fig. A-13. Surface Radiation Scans for the Building 3119 Slab

Fig. A-14. Alpha and Alpha-plus-Beta Scans Q-Plot for the Building 3119 Slab and

Remaining Walls

Fig. A-15. Gamma Scan Q-Plot for the Building 3119 Slab. A-24

Fig. A-16. Sampling and Direct Measurement Locations for the Building 3119 Slab and

Remaining Walls A-25

Fig. A-17. Surface Radiation Scans for the Building 3503 A-28

Fig. A-18. Alpha and Alpha-plus-Beta Scans Q-Plot for the Building 3503 Slab A-29

Fig. A-19. Gamma Q-Plot for the Building 3503 Slab A-30

Fig. A-20. Sampling and Direct Measurement Locations for the Building 3503 Slab A-31

Fig. A-21. Surface Radiation Scans for the Building 3504 Slab A-34

Fig. A-22. Alpha and Alpha Plus Beta Scan Q-Plot for the Building 3504 Slab A-35

Fig. A-23. Gamma Scan Q-Plot for the Building 3504 Slab. A-36

Fig. A-24. Sampling and Direct Measurement Locations for the Building 3504 Slab... A-37

Fig. A-25. Surface Radiation Scans for the Building 3508 Slab A-40

Fig. A-26. Alpha and Alpha Plus Beta Scan Q-Plot for the Building 3508 Slab A-41 
Fig. A-27. Gamma Scan Q-Plot for the Building 3508 Slab................................................................ A-42

Fig. A-28. Sampling and Direct Measurement Locations for the Building 3508 Slab.....................A-43

Fig. A-29. Surface Radiation Scans for the Building 3541 Slab ........................................................... A-46

Fig. A-30. Alpha and Alpha-plus-Beta Scan Q-Plot for the Building 3541 Slab.............................. A-47

Fig. A-31. Gamma Scan Q-Plot for the Building 3541 Slab...............................................................A-48

Fig. A-32. Sampling and Direct Measurement Locations for the Building 3541 Slab...................... A-49

Fig. A-33. Surface Radiation Scans for the Building 3543 Slab ......................................................... A-52

Fig. A-34. Alpha and Alpha Plus Beta Scan Q-Plot for the Building 3543 Slab ............................. A-53

Fig. A-35. Gamma Scan Q-Plot for the Building 3543 Slab................................................................ A-54

Fig. A-36. Sampling and Direct Measurement Locations for the Building 3543 Slab..................... A-55

Fig. A-37. Surface Radiation Scans for the Building 3592 Slab ........................................................ A-58

Fig. A-38. Alpha and Alpha-plus-Beta Scan Q-Plot for the Building 3592 Slab.............................. A-59

Fig. A-39. Gamma Scan Q-Plot for the Building 3592 Slab................................................................ A-60

Fig. A-40. Sampling and Direct Measurement Locations for the Building 3592 Slab..................... A-61

Fig. A-41. Surface Radiation Scans for the Building 3605 Slab ....................................................... A-64

Fig. A-42. Alpha and Alpha-plus-Beta Scan Q-Plot for the Building 3605 Slab.............................. A-65

Fig. A-43. Gamma Scan Q-Plot for the Building 3605 Slab................................................................. A-66

Fig. A-44. Sampling and Direct Measurement Locations for the Building 3605 Slab...................... A-67 


\section{TABLES}

Table 1. Surface Activity Measurement Ranges for the Central Campus and Southeast Lab Complex Building Slabs .8

Table A-1. Surface Activity Measurements for the Central Campus Building 3085 Slab ................. A-6

Table A-2. Radionuclide Surface Activity Measurements for the Central Campus

Building 3098 Slab

Table A-3. Radionuclide Surface Activity Measurements for the Central Campus

Building 3102 Slab

Table A-4. Radionuclide Surface Activity Measurements for the Central Campus

Building 3117A Slab.

Table A-5. Radionuclide Surface Activity Measurements for the Central Campus

Building 3119 Slab......

Table A-6. Radionuclide Activities for the Southeast Laboratory Complex

Building 3503 Slab......

Table A-7. Radionuclide Activities for the Southeast Laboratory Complex

Building 3504 Slab......

Table A-8. Radionuclide Activities for the Southeast Laboratory Complex

Building 3508 Slab.

Table A-9. Radionuclide Activities for the Southeast Laboratory Complex

Building 3541 Slab......

Table A-10. Radionuclide Activities for the Southeast Laboratory Complex

Building 3543 Slab......

Table A-11. Radionuclide Activities for the Southeast Laboratory Complex

Building 3592 Slab......

Table A-12. Radionuclide Activities for the Southeast Laboratory Complex

Building 3605 Slab 


\section{ACRONYMS}

$\begin{array}{ll}\text { cpm } & \text { counts per minute } \\ \text { DOE } & \text { U.S. Department of Energy } \\ \text { dpm } / 100 \mathrm{~cm}^{2} & \text { disintegration per minute per } 100 \text { square centimeters } \\ \text { ELCR } & \text { excess lifetime cancer risk } \\ \text { GM } & \text { General Maintenance } \\ \text { GPS } & \text { global positioning system } \\ \text { HPS } & \text { Health Physics Society } \\ \text { IV } & \text { independent verification } \\ \text { NaI } & \text { sodium iodide } \\ \text { ORAU } & \text { Oak Ridge Associated Universities } \\ \text { ORISE } & \text { Oak Ridge Institute for Science and Education } \\ \text { ORNL } & \text { Oak Ridge National Laboratory } \\ \text { Q } & \text { quantile } \\ \text { ROD } & \text { Record of Decision } \\ \text { SEC } & \text { Safety and Ecology Corporation } \\ \text { VSP } & \text { Visual Sample Plan }\end{array}$




\section{INDEPENDENT VERIFICATION OF THE CENTRAL CAMPUS AND SOUTHEAST LABORATORY COMPLEX BUILDING SLABS AT OAK RIDGE NATIONAL LABORATORY, OAK RIDGE, TENNESSEE}

\section{INTRODUCTION}

Oak Ridge Associated Universities (ORAU), working under the Oak Ridge Institute for Science and Education (ORISE) contract with the U.S. Department of Energy (DOE), has performed independent verification (IV) of Central Campus and Southeast Laboratory Complex building slabs located at Oak Ridge National Laboratory (ORNL). Safety and Ecology Corporation (SEC) has submitted final status survey data indicating completion of removal actions to meet site requirements for the following building slabs or structures: Buildings 3085, 3098, 3119, 3503, 3504, 3508, 3541, 3543, 3592, and 3605, and sub-grade containment structures 3102 and 3117A. All above-grade building structures, tanks, and systems have been characterized, demolished, and disposed as part of the American Recovery and Reinvestment Act of 2009. Any residual contamination that remains on the slabs or containment structures must meet contractual end-point criteria in accordance with the limits defined in the Bethel Valley Record of Decision (ROD) (DOE 2002).

ORAU survey teams conducted survey activities during the period between January and June, 2012 on behalf of DOE to verify the final radiological condition reported by SEC is reproducible. The DOE requires that the "as left" status of the slab condition be verified to ensure that the residual radioactivity does not exceed the guidance provided in the Bethel Valley ROD and that any issues of conflict can be addressed immediately. The potential radiological inventory, based on process knowledge, includes Cs-137, Sr-90, Th-232, U-235, U-238, Pu-239/240, and Am-241.

\section{SITE DESCRIPTION}

ORNL is located in Oak Ridge, Tennessee, approximately 25 miles west of Knoxville at the western end of Bethel Valley Road. The site occupies approximately 10,000 acres of the Oak Ridge Reservation and is bounded to the south by the Clinch River and to the north by Bethel Valley Road. The former Central Campus facilities were centrally located on the main ORNL campus to the north of Central Avenue and the former Southeast Laboratory Complex facilities are located 
south of Central Avenue (as shown in Fig. 1). These facilities were utilized to house various offices and laboratories, and fabrication, operational, and support processes.

\section{OBJECTIVE}

The objective of this verification survey was to provide independent review and field assessment of remediation actions conducted by SEC, and to independently assess whether the final radiological condition of the slabs met the release guidelines as referenced in the ROD.

\section{PROCEDURES}

ORAU survey activities were performed in accordance with the final Project-Specific Plan for Independent Verification of Building Slabs at Oak Ridge National Laboratory (ORISE 2011). Procedures supporting the field implementation of the plan were obtained from the ORISE Survey Procedures Manual and the ORAU Quality Program Manual (ORISE 2012a and ORAU 2012).

\subsection{Document REVIEW}

SEC provided ORAU final status survey data for each slab. These data were reviewed as a part of the overall assessment to ensure that actions by the contractor had met the specified criteria.

\subsection{REFERENCE SYSTEM}

ORAU used a global positioning system (GPS) for tracking survey data and identifying measurement and sampling locations. In most cases, GPS units were integrated with a ratemeter-scaler and detector to collect position and radiation count rate data. The specific geographic coordinate system required for documentation was the Tennessee State Plane Coordinate System. GPS coordinates are typically accurate to within one meter of any given position. When GPS units were not used, a hand-held distance meter was used to establish coordinate locations to identify sampling and measurement locations for several of the smaller slabs. In other cases when scan data could not be electronically captured, the scan ranges were observed and recorded in the site logbook and/or on slab drawings. Measurement locations were either geo-referenced or referenced to a prominent site feature. Standard orientation for measurement positions is referenced to the SW corner of a building slab. 


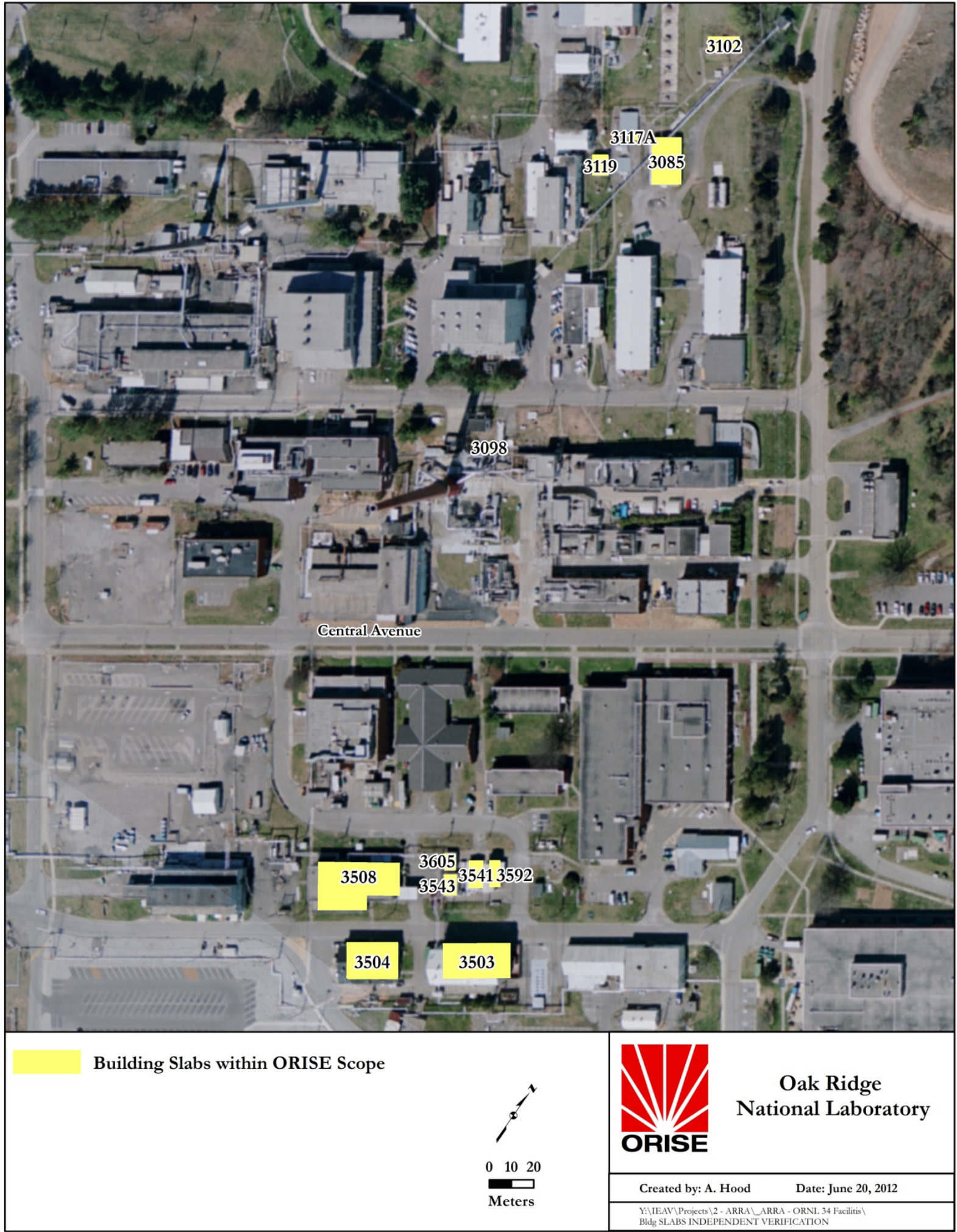

Fig. 1. Overview of Oak Ridge National Laboratory Central Campus and Southeast Laboratory Complex 


\subsection{SURFACE SCANS}

High-density scans were performed for alpha, alpha-plus-beta, and gamma radiation on the slabs' surfaces, with the exception of slabs that had been re-covered with new concrete. Particular attention was given to areas with the highest potential for contamination (i.e., cracks, joints, and surface run-off pathways).

A large-area gas proportional detector was used for alpha and alpha-plus-beta radiation, and gamma radiation scans were performed using a 2 inch $\times 2$ inch sodium iodide, thallium-activated $(\mathrm{NaI}[\mathrm{Tl}])$ detector. Detectors were coupled to ratemeter-scalers that supported data logging capabilities with audible indication. The data loggers electronically captured the count rates each second and converted the data to counts per minute (cpm) equivalents. ORAU field personnel relied on audio output for real-time identification of locations of elevated direct radiation that might suggest the presence of residual contamination. These judgmental locations were marked and identified for further investigation.

\subsection{Surface ACtivity Measurements}

Direct static measurements of alpha and alpha-plus-beta surface activity were obtained at predetermined randomly-generated locations based on a statistical sampling design facilitated by using Visual Sample Plan (VSP) software (version 6.0 or greater). The number of measurement locations was adjusted based on the size or condition of the pad. The typical number of predetermined locations was 11 , based on a non-parametric statistical determination of the number of samples required to estimate and quantify the mean activity level. Non-parametric statistics do not require the assumption of a normal distribution for the population of interest (i.e., surface activity). These predetermined measurement locations were supplemented by the addition of judgmental measurement locations. The judgmental data are used to assess locations of elevated radiation identified by surface scans that could potentially be above acceptable surface contamination guidelines. Smears (47-mm diameter numbered filter paper discs) were used to sample an area of $100 \mathrm{~cm}^{2}$ at each static measurement location for removable gross alpha and beta contamination. Direct measurement locations are provided for individual slabs in Appendix A. 


\subsection{SAMPLE ANALYSIS AND DATA INTERPRETATION}

Smear samples and data were returned to the ORAU/ORISE facility in Oak Ridge, Tennessee for analysis and interpretation. Smears were analyzed, in accordance with the ORISE Laboratory Procedures Manual, for gross alpha and beta activity using a low-background proportional counter (ORISE 2012b). Total and removable surface activity measurement results were corrected for background, then converted to units of disintegration per minute per 100 square centimeters $\left(\mathrm{dpm} / 100 \mathrm{~cm}^{2}\right)$. The gross count rates for alpha, alpha-plus-beta, and gamma radiation surface scan data for each slab were prepared for report presentation using Quantile (Q) plots. The Q-plot is a graphical technique for determining if there is a common distribution in data sets. The advantage of the Q-plot is that population distributional aspects can be evaluated simultaneously. The detectable aspects include:

- Shifts in scale

- Changes in symmetry (skewness of the data)

- The presence of outliers

Q-plots were generated by uploading the survey area data into the U.S. Environmental Protection Agency's ProUCL software. In the Q-plots provided in Appendix A, the Y-axis represents observed count rates in cpm. The $\mathrm{X}$-axis represents the data quantiles about the mean value. A normal distribution that is not skewed by outliers will appear as a straight line with the slope of the line subject to the degree of variability among the data population (i.e., a background radiation population). Values less than the mean are represented in the negative quantiles, and values greater than the mean are represented in the positive quantiles. The presence of more than one population-e.g., background radiation population and contamination-would display on a Q-plot as a step function. Small areas of localized contamination will appear on the Q-plot as outlier points in the upper right quadrant. 


\section{APPLICABLE RESIDUAL CONTAMINATION GUIDELINES}

For structural surfaces that may remain in place, the "as left" condition must meet industrial surface criteria derived to achieve the same average excess lifetime cancer risk (ELCR) of $1 \times 10^{-4}$ and the maximum risk level at ten times the average as defined in the ROD. The industrial surface criteria are applicable to the entire exposed surface of the slab (DOE 2002).

Surface criteria cited in the ROD have been derived based on American National Standard Institute /Health Physics Society (HPS) HPS N13.12-1999 (HPS 1999). This standard specifies screening levels for clearance of surfaces containing residual radioactive materials, based on a dose limit of $1 \mathrm{mrem} /$ year, for several groups of radionuclides. Clearance, as defined by the standard, is "the removal of items or materials that contain residual levels of radioactive materials within authorized practices from any further control of any kind" (DOE 2002). The primary radionuclides of concern specified for building surfaces in Bethel Valley (ORNL) are classified in Group 2, per the standard (DOE 2002). This includes uranium and selected high-dose beta-gamma emitters. However, recent characterization data indicate that Group 1 radionuclides radium, thorium, and transuranics (Th-232, $\mathrm{Pu}-239 / 240$, and Am-241) are present in the radionuclide mix. The surface activity screening level for Group 1 radionuclides is specified at $600 \mathrm{dpm} / 100 \mathrm{~cm}^{2}$, and for Group 2 radionuclides the level is $6,000 \mathrm{dpm} / 100 \mathrm{~cm}^{2}$ (HPS 1999). This screening level has been used to derive a risk-based surface concentration limit as follows (DOE 2002):

RLsurf $=\mathrm{TR} /[\mathrm{DL} / \mathrm{SL} \times \mathrm{R} \times \mathrm{ED}]=1 \times 10^{-4} \mathrm{ELCR} /\left[(1 \mathrm{mrem} / \mathrm{yr}) /\left(6,000 \mathrm{dpm} / 100 \mathrm{~cm}^{2}\right) \times\right.$ $6 \times 10^{-7} \mathrm{ELCR} / \mathrm{mrem} \times 25$ years $]=40,000 \mathrm{dpm} / 100 \mathrm{~cm}^{2}$

where:

- $\quad$ RLsurf $=$ remediation levels for residual building surfaces

- $\quad \mathrm{TR}=$ target risk level $=1 \times 10^{-4} \mathrm{ELCR}$

- $\mathrm{DL}=$ dose limit used to derive surface screening level $=1 \mathrm{mrem} /$ year

- $\mathrm{SL}=$ surface activity screening level for Group 2 radionuclides $=6,000 \mathrm{dpm} / 100 \mathrm{~cm}^{2}$

- $\mathrm{R}=$ cancer risk per unit dose for surface-deposited radioactivity (conservatively based on radionuclide-specific slope factor and external dose coefficient for $\left.{ }^{137} \mathrm{Cs}+\mathrm{D}\right)=6 \times 10^{-7}$ $\mathrm{ELCR} / \mathrm{mrem}$

- $\mathrm{ED}=$ exposure duration $=25$ years for industrial scenario. This calculation is equivalent for Group 1 radionuclides using the specified $600 \mathrm{dpm} / 100 \mathrm{~cm}^{2}$ surface activity screening value. 
NOTE: The derived RLsurf value is based on the assumption that a worker could potentially be located directly above the building surfaces for 2,000 hours per year. Since it is unlikely that any worker would actually occupy this location for such an extended period of time, this estimate is considered conservative and any actual risk may be well below the target level of $1 \times 10^{-4}$ ELCR. Additional conservative assumptions are the absence of any consideration of the decreasing concentrations of radionuclides on the building surfaces due to radioactive decay or the shielding effects from backfill of basements and other subsurface structures (DOE 2002).

\section{FINDINGS AND RESULTS}

The results of the IV surveys of the slabs are discussed below. Appendix A provides the data summaries for each individual slab. Data summaries include surface walkover scan results for each radiation type collected for the slab, Q-Plots, static measurement and smear sample location maps, and results tables of total and removable surface activity levels. Direct field measurement data are compared to the criteria specified in the ROD to determine if the "as left" conditions have been met. Removable surface activity results are evaluated against DOE Order 458.1, which references DOE Order 5400.5, for allowable alpha and beta removable activity (DOE 1993, 2002, and 2011).

\subsection{SURFACE SCANS}

Scan density schematics for each building slab is provided in Appendix A with the exception of the 3102 and 3117A slabs. The Building 3102 and 3117A Slabs are both subgrade structures with all four walls inplace; however, 3102 had a new concrete pour that covered the original slab and the 3117A structure was too small to use the spatial data loggers. Alpha activity scans ranged from $0 \mathrm{cpm}$ to $860 \mathrm{cpm}$ and alpha-plus-beta activity scans ranged from $0 \mathrm{cpm}$ to 48,000 cpm. Gamma radiation scans over the surface of the slabs ranged from less than 6,000 cpm up to $330,000 \mathrm{cpm}$. Scan data were used as a qualitative indication of areas where radioactivity levels required additional investigations.

\subsection{Total and Removable Surface Activity LeVELS}

Surface activity measurement results are summarized in Table 1. Total alpha measurements ranged from -16 to $32,000 \mathrm{dpm} / 100 \mathrm{~cm}^{2}$ and alpha plus beta from -340 to $96,000 \mathrm{dpm} / 100 \mathrm{~cm}^{2}$. The 
highest total and removable activity was measured on the Building 3508 slab. The Building 3508 slab had the highest removable alpha activity at $27 \mathrm{dpm} / 100 \mathrm{~cm}^{2}$.

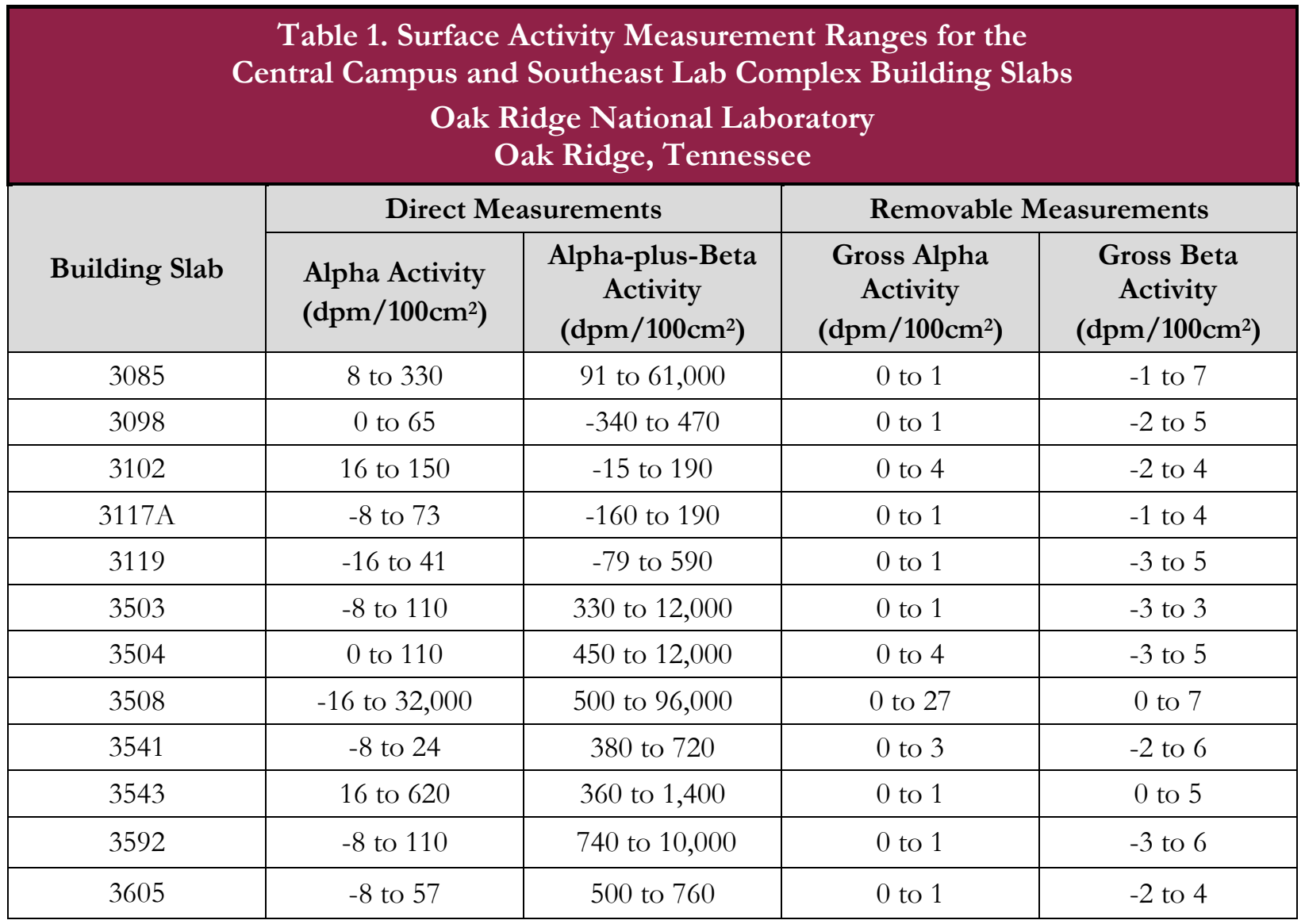

\subsection{COMPARISON OF RESULTS WITH GUIDELINES}

The remediation level guideline for Group 2 radionuclides is $40,000 \mathrm{dpm} / 100 \mathrm{~cm}^{2}$ for allowable fixed activity. Total surface activity levels on ten of the twelve slabs were within the remediation level guideline of $40,000 \mathrm{dpm} / 100 \mathrm{~cm}^{2}$ for remaining fixed contamination. The surface activity levels on Building 3085 and 3508 slabs were as high as 61,000 dpm/100 $\mathrm{cm}^{2}$ and $96,000 \mathrm{dpm} / 100 \mathrm{~cm}^{2}$, respectively. The detection of measurable fixed alpha activity concludes that Group 1 radionuclides are present. The Group 1 radionuclides guideline is $4,000 \mathrm{dpm} / 100 \mathrm{~cm}^{2}$ when using the surface activity screening level for Group 1 radionuclides of $600 \mathrm{dpm} / 100 \mathrm{~cm}^{2}$ to calculate the derived risk-based surface concentration. The highest fixed alpha contamination was found on the Building 3508 slab at 32,000 dpm/100 $\mathrm{cm}^{2}$. 


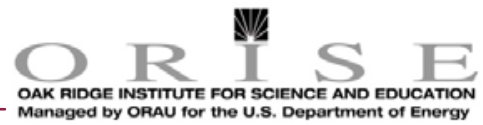

Neither the ROD nor HPS N13.12-1999 provide remediation guidelines for removable activity.

Therefore, removable contamination activity levels were compared with the DOE Order 5400.5

guidance for acceptable activity levels. The most restrictive alpha and beta removable surface activity per DOE Order 5400.5 are 20 and $200 \mathrm{dpm} / 100 \mathrm{~cm}^{2}$, respectively. Based on the results, removable alpha contamination exceeding the guidance was identified on the slab of Building 3508 at $27 \mathrm{dpm} / 100 \mathrm{~cm}^{2}$.

\section{SUMMARY}

During the period between February 2012 and June 2012, ORAU performed verification surveys on former Central Campus and Southeast Laboratory Complex building slabs at ORNL. The survey included direct radiation surface scans, total surface activity measurements, and the collection of smear samples for determining removable surface activity levels. Scans for alpha and alpha-plus-beta radiation levels identified radiation activity levels exceeding the 40,000 dpm/100 $\mathrm{cm}^{2}$ Group 2 radionuclide surface remediation level guidelines on the Building 3085 and 3508 slabs. The high activity levels were found in small localized areas (i.e., divets, holes, and cracks). One smear collected from the 3508 slab exceeded the DOE Order 5400.5 guidance for removable activity. ORAU field personnel notified SEC of the survey findings for immediate action. A recheck of the these locations determined that SEC grouted areas on both pads that had been marked by ORAU. Activity levels were then verified by ORAU to be within the guidelines. Therefore, ORAU is of the opion that the Central Campus and Southeast Laboratory Complex building slabs meet the "as left" condition per the ROD for fixed radioactivity. 


\section{REFERENCES}

HPS 1999. Surface and Volume Radioactivity Standards for Clearance. Health Physics Society.

McLean, Virginia. August 31.

ORAU 2012. Quality Program Manual for the Independent Environmental Assessment and Verification Program. Oak Ridge Associated Universities. Oak Ridge, Tennessee. June 28.

ORISE 2012b. Survey Procedures Manual for the Independent Environmental Assessment and Verification Program. Oak Ridge Institute for Science and Education, managed by Oak Ridge Associated Universities. Oak Ridge, Tennessee. May 11.

ORISE 2011a. Project-Specific Plan for the Independent Verification of Building Slabs and Concrete Structures at Oak Ridge National Laboratory, Oak. Ridge, Tennessee. Oak Ridge Institute for Science and Education, managed by Oak Ridge Associated Universities. 5086-PL-01-0. July.

ORISE 2012c. Laboratory Procedures Manual for the Independent Environmental Assessment and Verification Program. Oak Ridge Institute for Science and Education, managed by Oak Ridge Associated Universities. Oak Ridge, Tennessee. April 25.

DOE 1993. DOE Order 5400.5 Radiation Protection of the Public and the Environment. U.S. Department of Energy. Washington, DC. January 7.

DOE 2002. Record of Decision for Interim Actions in Bethel Valley. U.S. Department of Energy. Oak Ridge, Tennessee. May.

DOE 2011. DOE Order 458.1, Chg 1, Radiation Protection of the Public and the Environment. U.S. Department of Energy. Washington, D.C. March 8. 
APPENDIX A

\section{DATA PACKAGES FOR INDIVIDUAL BUILDING SLABS}


3085 BUILDING SLAB 


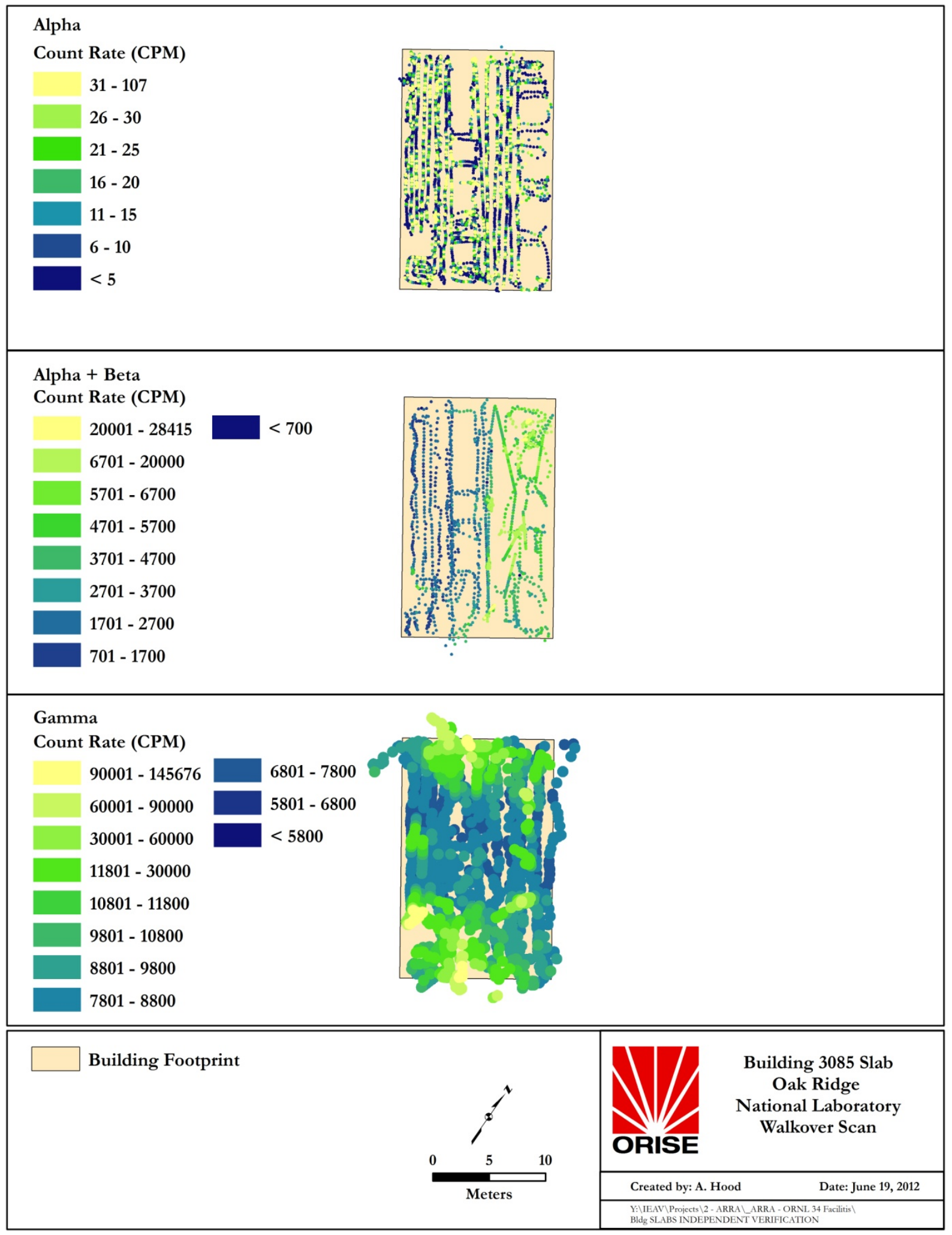

Fig. A-1. Surface Radiation Scans for the Building 3085 Slab 
Building 3085 Slab Alpha and Alpha-plus-Beta Q Plot Summary Statistics for Raw Full Dataset

\begin{tabular}{|c|c|c|c|c|c|c|}
\hline Variable & NumObs & Min & Max & Mean & Median & SD \\
\hline Alpha & 3,719 & 0 & 107 & 16 & 10 & 17 \\
\hline Alpha-plus-Beta & 1,972 & 0 & 28,415 & 5,060 & 3,602 & 5,077 \\
\hline
\end{tabular}

$3000000 \quad$ Building 3085 Slab: Q Plot for Alpha and Alpha + Beta

30000.00

26000.00

24000.00

22000.00

20000.00

है 18000.00

$\stackrel{0}{U}_{16000.00}$

䒕 14000.00

12000.00

ᄃ 10000.00

ن 8000.00

6000.00

4000.00

2000.00

0.00

$-2000.00$

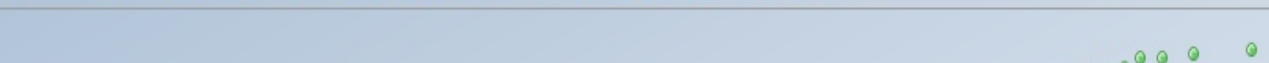

$x$

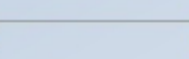

3

\3085 Alpha

3085 Alpha Beta

Fig. A-2. Alpha and Alpha-plus-Beta Scans Q-Plot for the Building 3085 Slab 


\begin{tabular}{|c|c|c|c|c|c|c|}
\hline \multicolumn{7}{|c|}{$\begin{array}{c}\text { Building 3085 Slab Gamma Q Plot } \\
\text { Summary Statistics for Raw Full Dataset }\end{array}$} \\
\hline Variable & NumObs & Min & Max & Mean & Median & SD \\
\hline Gamma & 1,685 & 6610 & 145,676 & 16,916 & 9,644 & 20,353 \\
\hline
\end{tabular}

Building 3085: Q-Q Plot for Gamma

140000.00

130000.00

120000.00

110000.00

100000.00

틍 90000.00

웜 80000.00

苋 70000.0

蒙 60000.00

广 50000.00

40000.00

30000.00

20000.00

10000.00

0.00

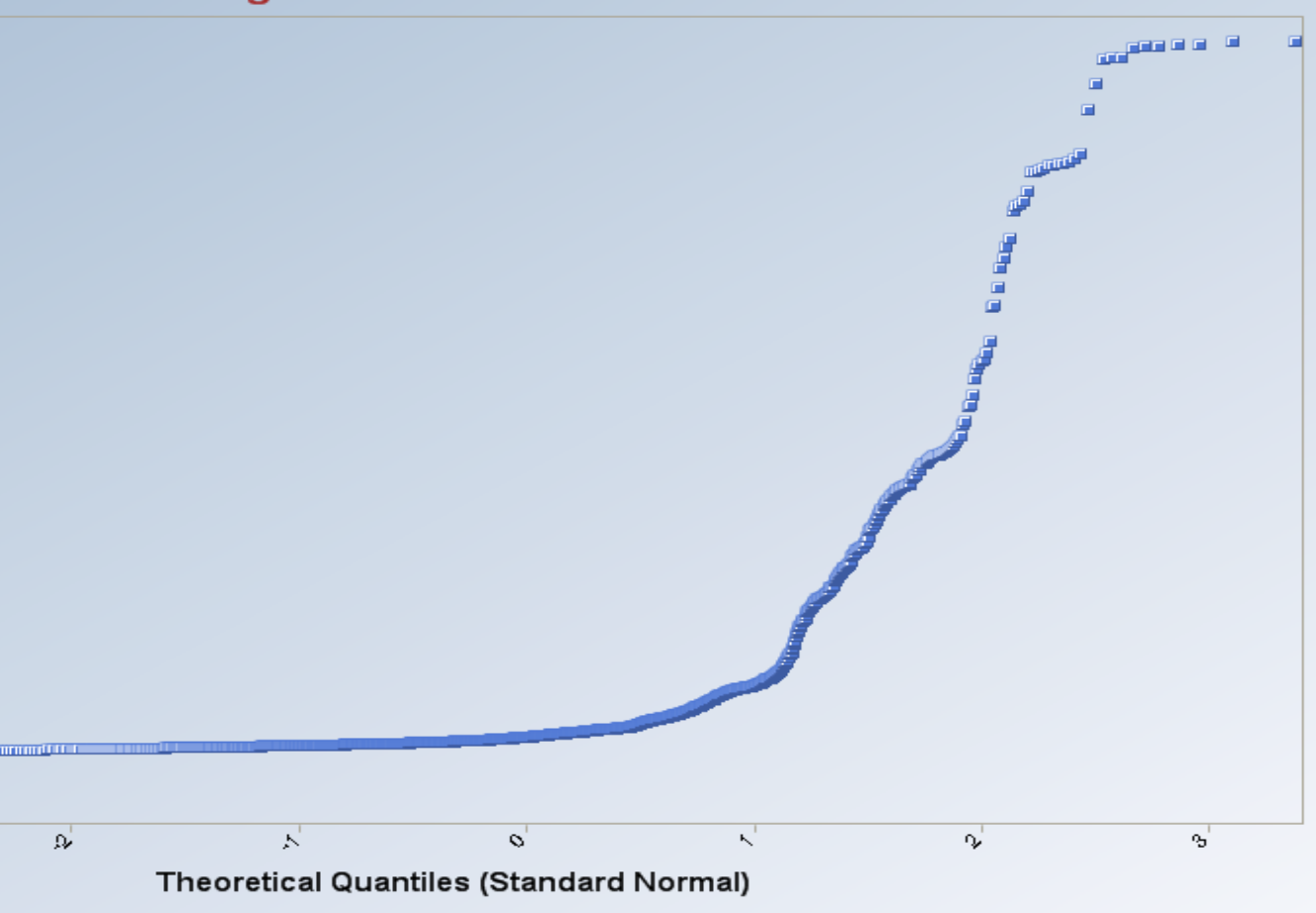

3

Theoretical Quantiles (Standard Normal)

\3085 Gamma

Fig. A-3. Gamma Scan Q-Plot for the Building 3085 Slab 


\section{Building 3085}

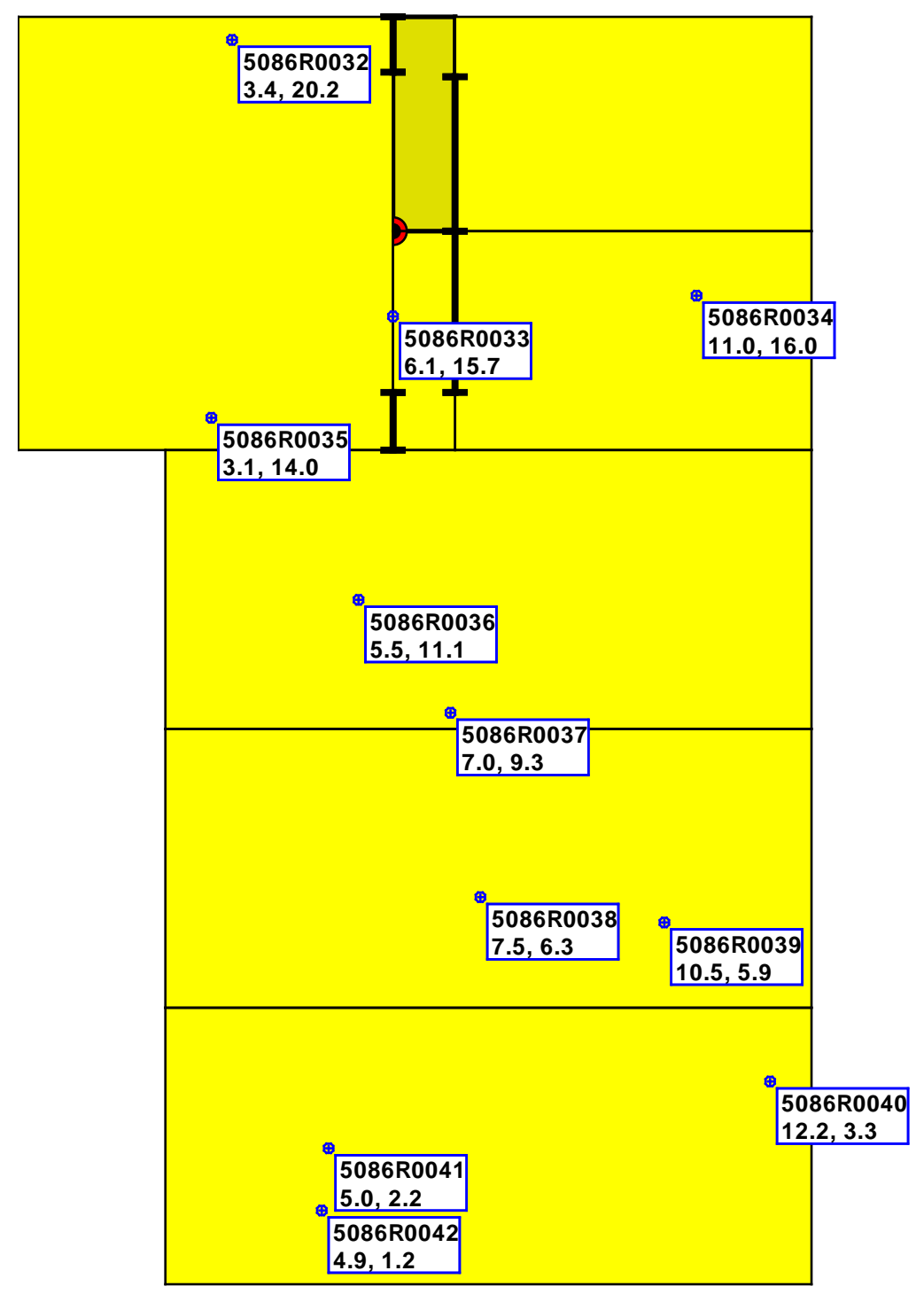

Fig. A-4. Sampling and Direct Measurement Locations for the Building 3085 Slab 


\begin{tabular}{|c|c|c|c|c|c|c|}
\hline \multicolumn{7}{|c|}{$\begin{array}{c}\text { Table A-1. Surface Activity Measurements for the } \\
\text { Central Campus Building } 3085 \text { Slab } \\
\text { Oak Ridge National Laboratory } \\
\text { Oak Ridge, Tennessee }\end{array}$} \\
\hline \multirow[b]{3}{*}{$\begin{array}{c}\text { Measurement } \\
\text { Location/Sample ID }\end{array}$} & \multicolumn{4}{|c|}{ Total Activity } & \multirow{2}{*}{\multicolumn{2}{|c|}{$\begin{array}{l}\text { Removable Activity } \\
\text { Gross Alpha \& Beta }\end{array}$}} \\
\hline & \multicolumn{2}{|c|}{ Alpha } & \multicolumn{2}{|c|}{ Alpha-plus-Beta } & & \\
\hline & $\begin{array}{l}\text { Gross } \\
\text { cpm }\end{array}$ & $\begin{array}{c}\text { Activity } \\
\left(\mathrm{dpm} / 100 \mathrm{~cm}^{2}\right)\end{array}$ & $\begin{array}{l}\text { Gross } \\
\text { cpm }\end{array}$ & $\begin{array}{c}\text { Activity } \\
\left(\mathrm{dpm} / 100 \mathrm{~cm}^{2}\right)\end{array}$ & $\begin{array}{c}\text { Alpha } \\
\text { Activity } \\
\left(\mathrm{dpm} / 100 \mathrm{~cm}^{2}\right)\end{array}$ & $\begin{array}{c}\text { Beta } \\
\text { Activity } \\
\left(\mathrm{dpm} / 100 \mathrm{~cm}^{2}\right)\end{array}$ \\
\hline \multicolumn{7}{|c|}{3085 Slab } \\
\hline 5086R0032 & 17 & 110 & 453 & 390 & 0 & 1 \\
\hline 5086R0033 & 20 & 140 & 350 & 91 & 0 & 0 \\
\hline 5086R0034 & 25 & 180 & 394 & 220 & 0 & 2 \\
\hline 5086R0035 & 33 & 240 & 363 & 130 & 1 & 0 \\
\hline 5086R0036 & 24 & 170 & 479 & 470 & 0 & 3 \\
\hline 5086R0037 & 43 & 330 & 399 & 240 & 1 & 0 \\
\hline 5086R0038 & 31 & 230 & 402 & 240 & 1 & 1 \\
\hline 5086R0039 & 13 & 81 & 554 & 690 & 0 & 2 \\
\hline 5086R0040 & 4 & 8 & 367 & 140 & 0 & 1 \\
\hline 5086R0041 & 5 & 16 & 377 & 170 & 0 & 0 \\
\hline 5086R0042 & 8 & 41 & 397 & 230 & 1 & 2 \\
\hline 5086R0134 & 21 & 150 & 5,993 & 17,000 & 0 & 7 \\
\hline 5086R0135 & 7 & 33 & 21,147 & 61,000 & 0 & 0 \\
\hline
\end{tabular}


3098 BUILDING SLAB 

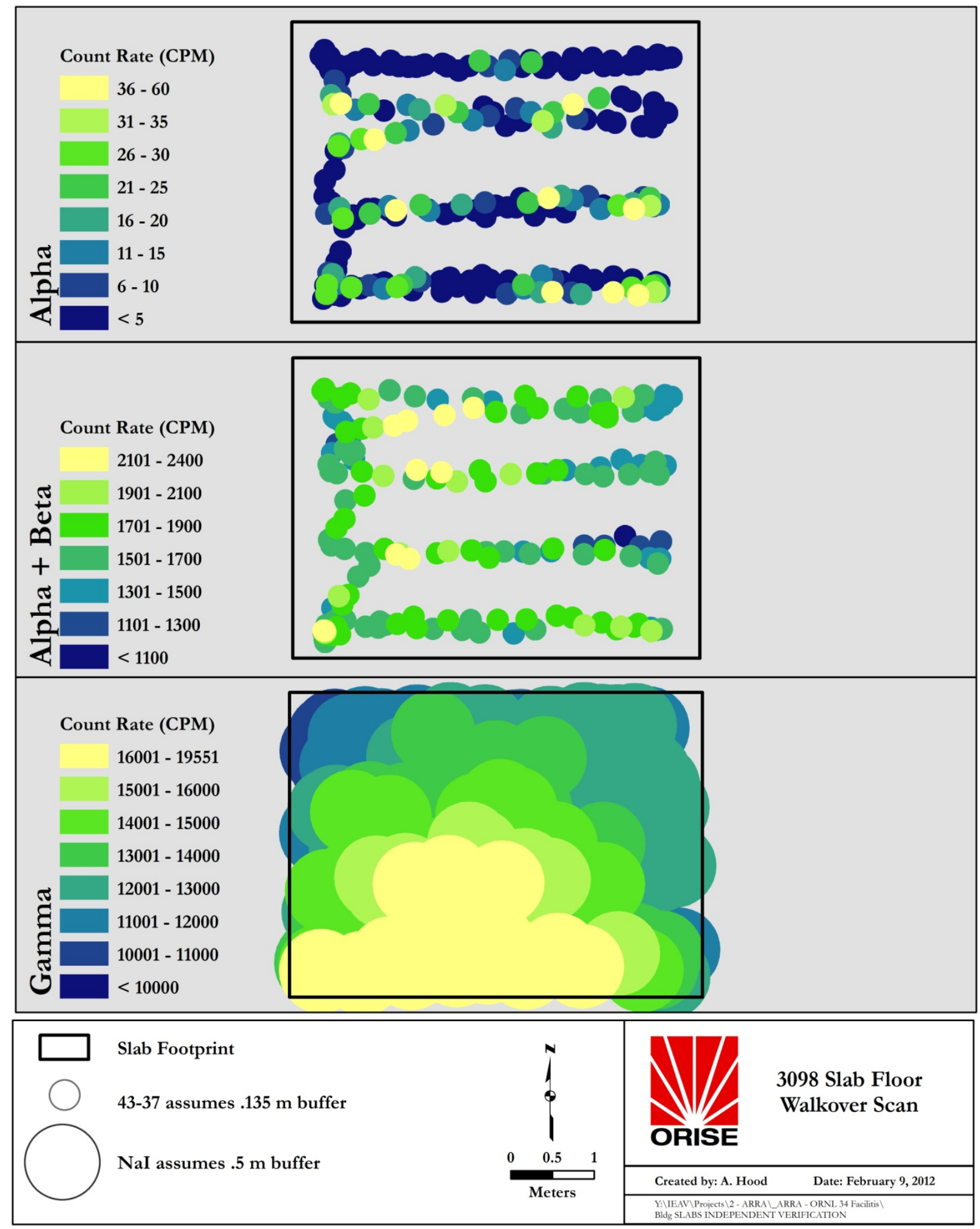

Fig. A-5. Surface Radiation Scans for the Building 3098 Slab 

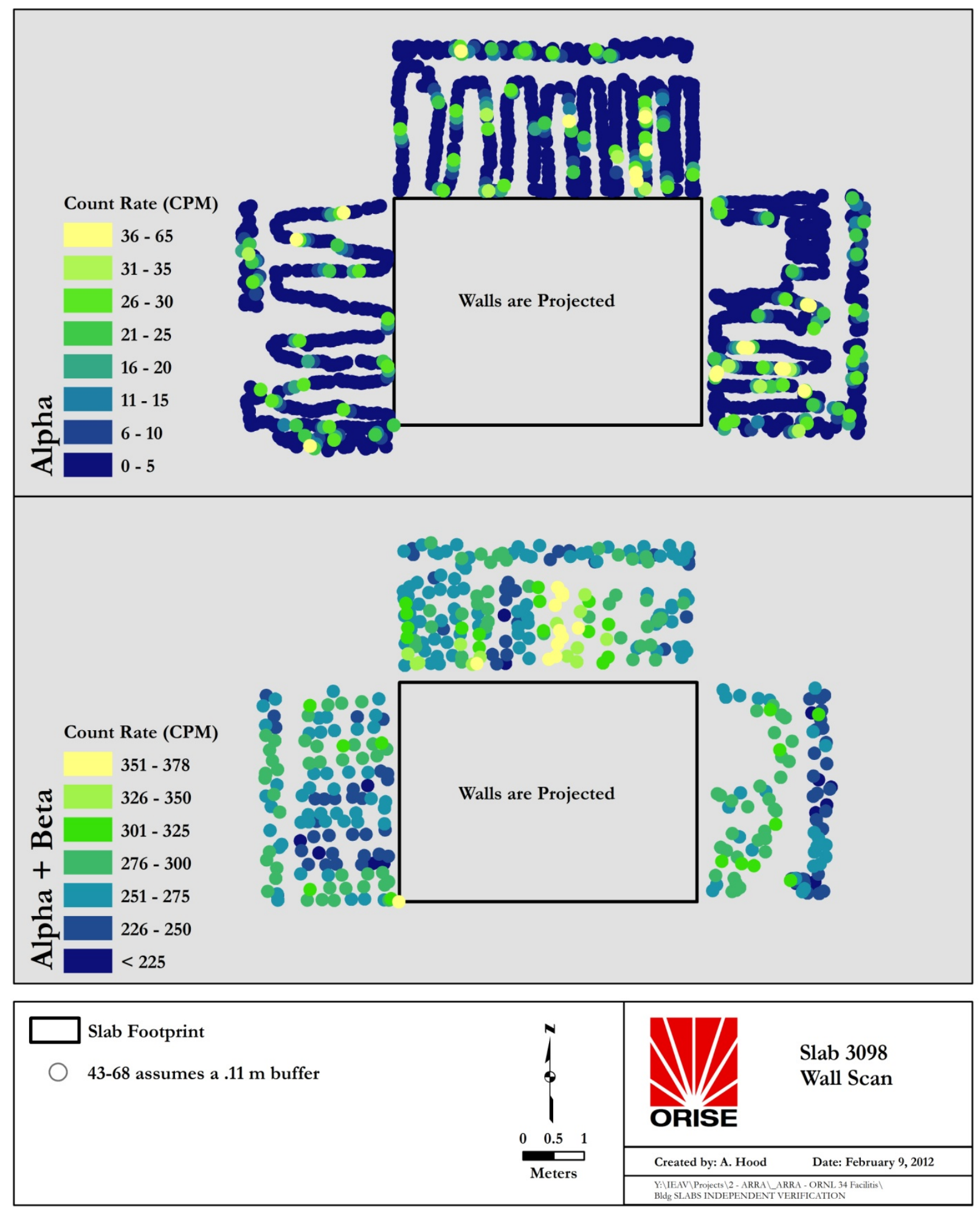

Fig. A-6. Surface Radiation Scans for the Building 3098 Remaining Walls 


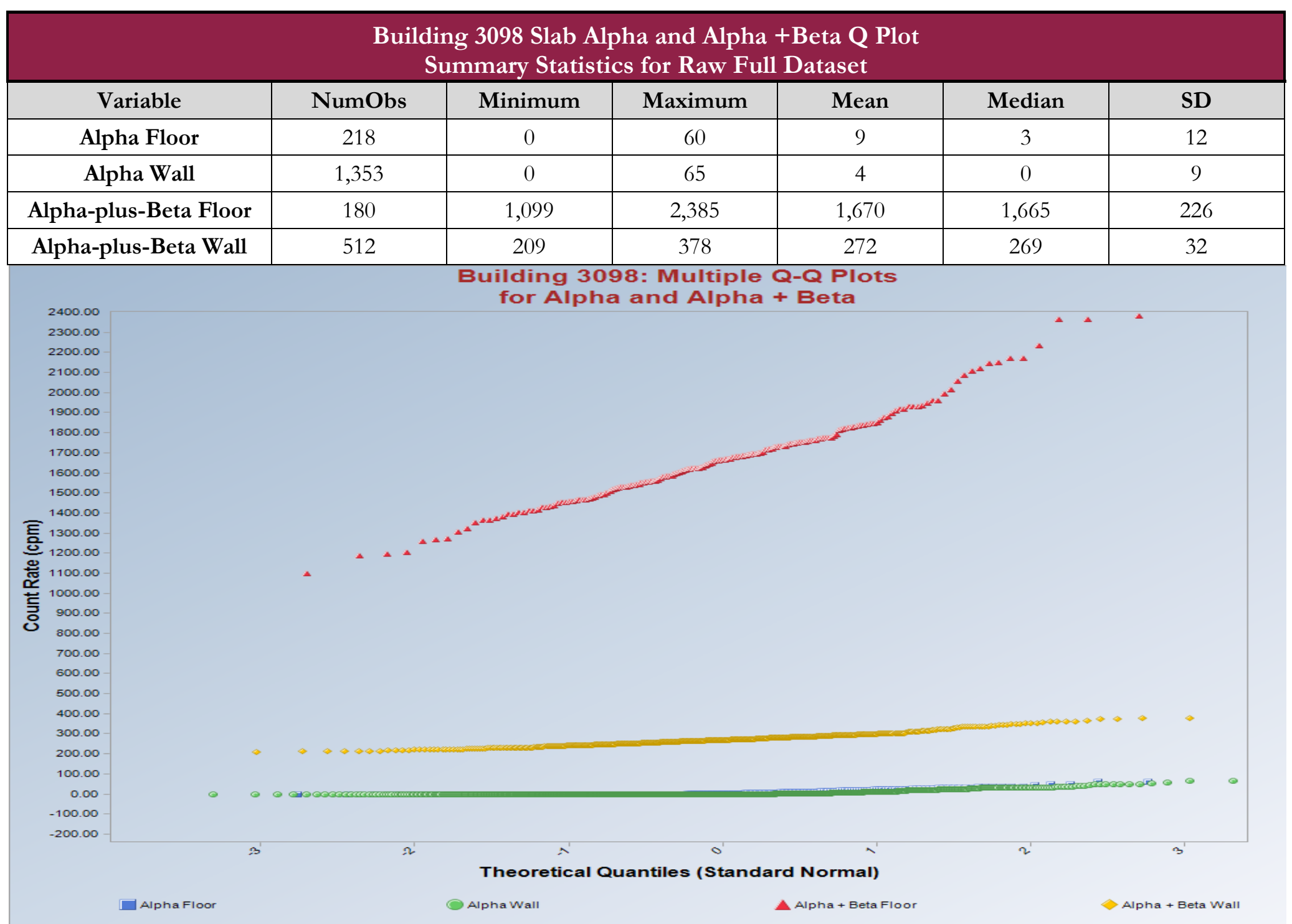

Fig. A-7. Alpha and Alpha-Plus-Beta Scan Q-Plot for the Building 3098 Slab 


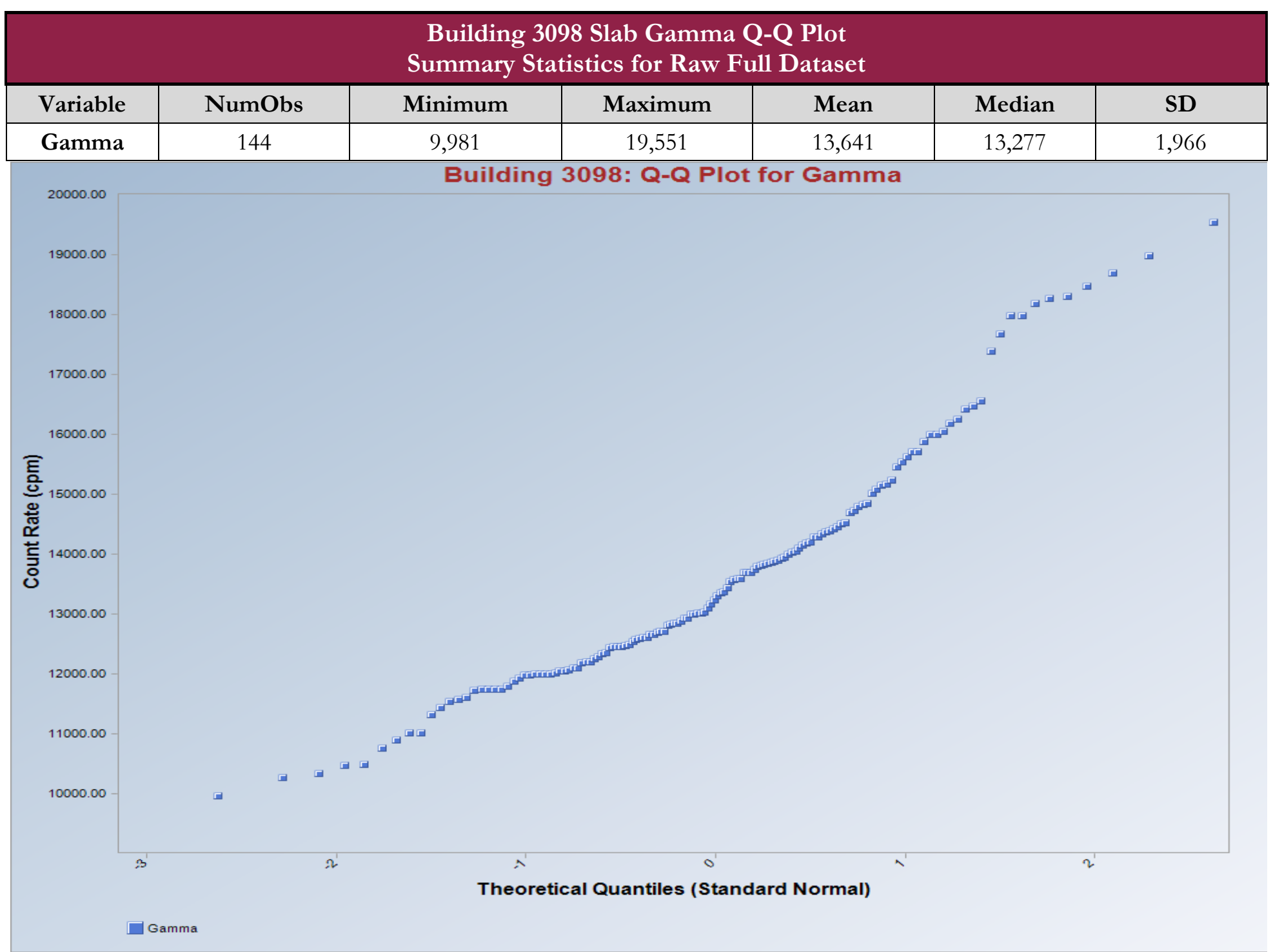

Fig. A-8. Gamma Scan Q-Plot for the Building 3098 Slab 


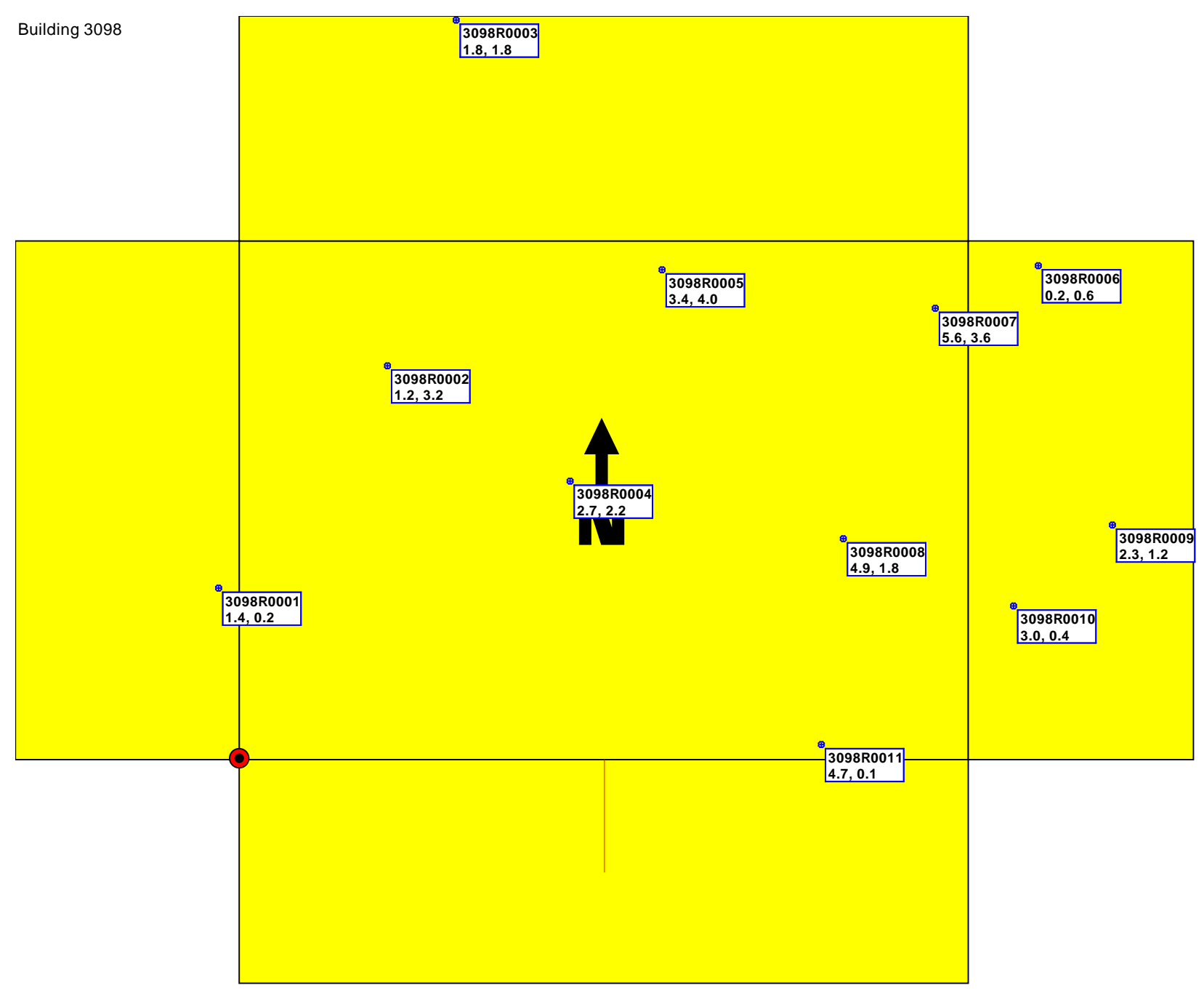

Fig. A-9. Sampling and Direct Measurement Locations for the Building 3098 Slab 


Table A-2. Radionuclide Surface Activity Measurements for the
Central Campus Building 3098 Slab
Oak Ridge National Laboratory
Oak Ridge, Tennessee


BUILDING 3102 SLAB 


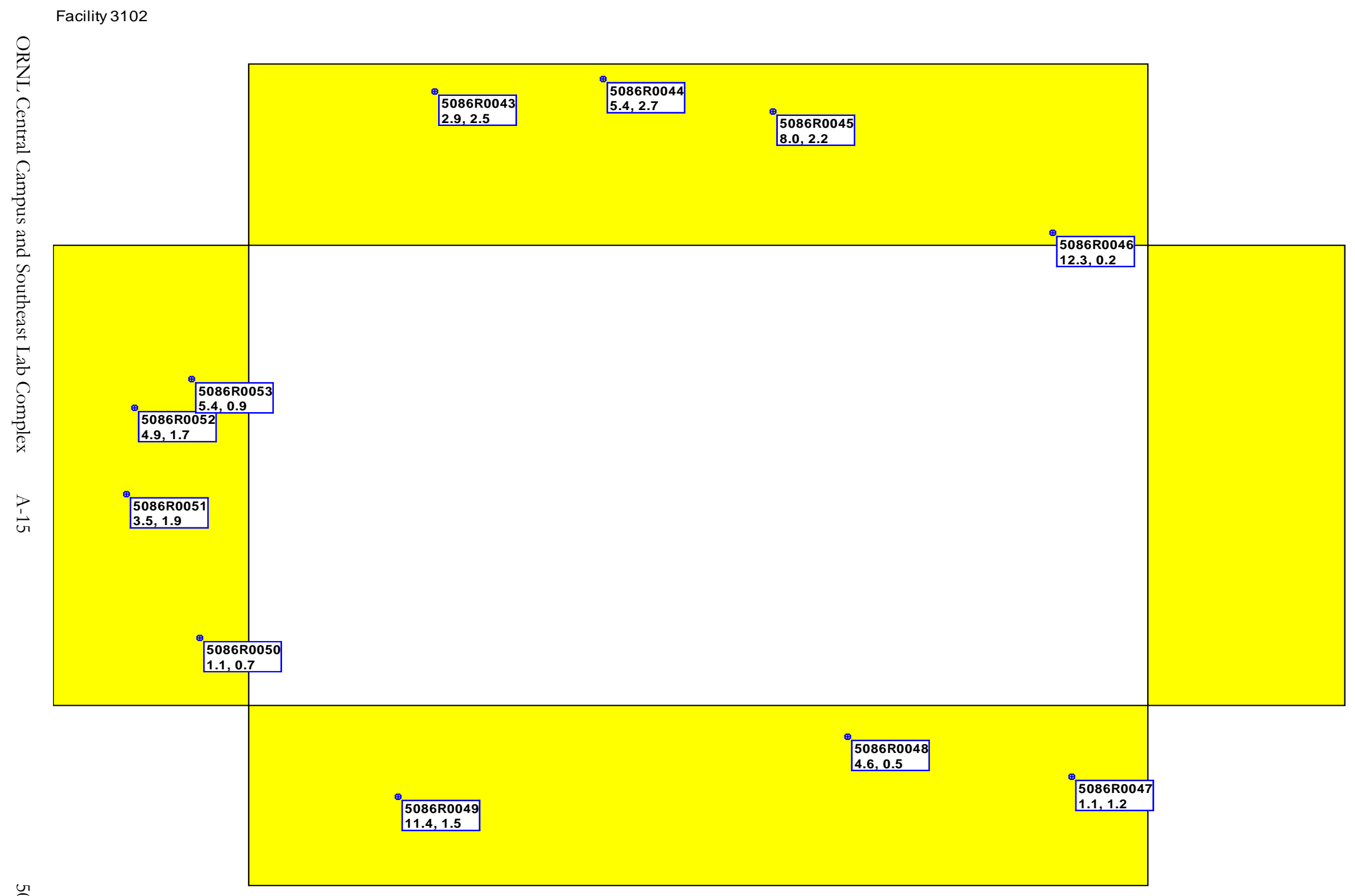

0
$\infty$
0
$\dot{1}$
0
0
$\dot{d}$
0

Fig. A-10. Sampling and Direct Measurement Locations for the Building 3102 Slab 


\begin{tabular}{|c|c|c|c|c|c|c|}
\hline \multicolumn{7}{|c|}{$\begin{array}{l}\text { Table A-3. Radionuclide Surface Activity Measurements for the } \\
\text { Central Campus Building } 3102 \text { Slab } \\
\text { Oak Ridge National Laboratory } \\
\text { Oak Ridge, Tennessee }\end{array}$} \\
\hline \multirow{3}{*}{$\begin{array}{c}\text { Measurement } \\
\text { Location/Sample ID }\end{array}$} & \multicolumn{4}{|c|}{ Total Activity } & \multirow{2}{*}{\multicolumn{2}{|c|}{$\begin{array}{l}\text { Removable Activity } \\
\text { Gross Alpha \& Beta }\end{array}$}} \\
\hline & \multicolumn{2}{|c|}{ Alpha } & \multicolumn{2}{|c|}{ Alpha-plus-Beta } & & \\
\hline & Gross cpm & $\begin{array}{c}\text { Activity } \\
\left(\mathrm{dpm} / 100 \mathrm{~cm}^{2}\right)\end{array}$ & Gross cpm & $\begin{array}{c}\text { Activity } \\
\left(\mathrm{dpm} / 100 \mathrm{~cm}^{2}\right)\end{array}$ & \begin{tabular}{|} 
Alpha Activity \\
$\left(\mathrm{dpm} / 100 \mathrm{~cm}^{2}\right)$
\end{tabular} & $\begin{array}{l}\text { Beta Activity } \\
\left(\mathrm{dpm} / 100 \mathrm{~cm}^{2}\right)\end{array}$ \\
\hline \multicolumn{7}{|c|}{3102 Slab } \\
\hline 5086R0043 & 13 & 81 & 356 & 110 & 4 & 0 \\
\hline 5086R0044 & 13 & 81 & 373 & 160 & 0 & 1 \\
\hline 5086R0045 & 10 & 57 & 360 & 120 & 0 & 1 \\
\hline 5086R0046 & 10 & 57 & 315 & -12 & 0 & 4 \\
\hline 5086R0047 & 10 & 57 & 373 & 160 & 0 & 0 \\
\hline 5086R0048 & 5 & 16 & 336 & 50 & 4 & 0 \\
\hline 5086R0049 & 8 & 41 & 384 & 190 & 1 & 0 \\
\hline 5086R0050 & 12 & 73 & 323 & 12 & 1 & 1 \\
\hline 5086R0051 & 22 & 150 & 320 & 3 & 4 & 1 \\
\hline 5086R0052 & 11 & 65 & 339 & 59 & 0 & 2 \\
\hline 5086R0053 & 12 & 73 & 314 & -15 & 4 & 1 \\
\hline
\end{tabular}


BUILDING 3117A SLAB 
$3117 \mathrm{~A}$

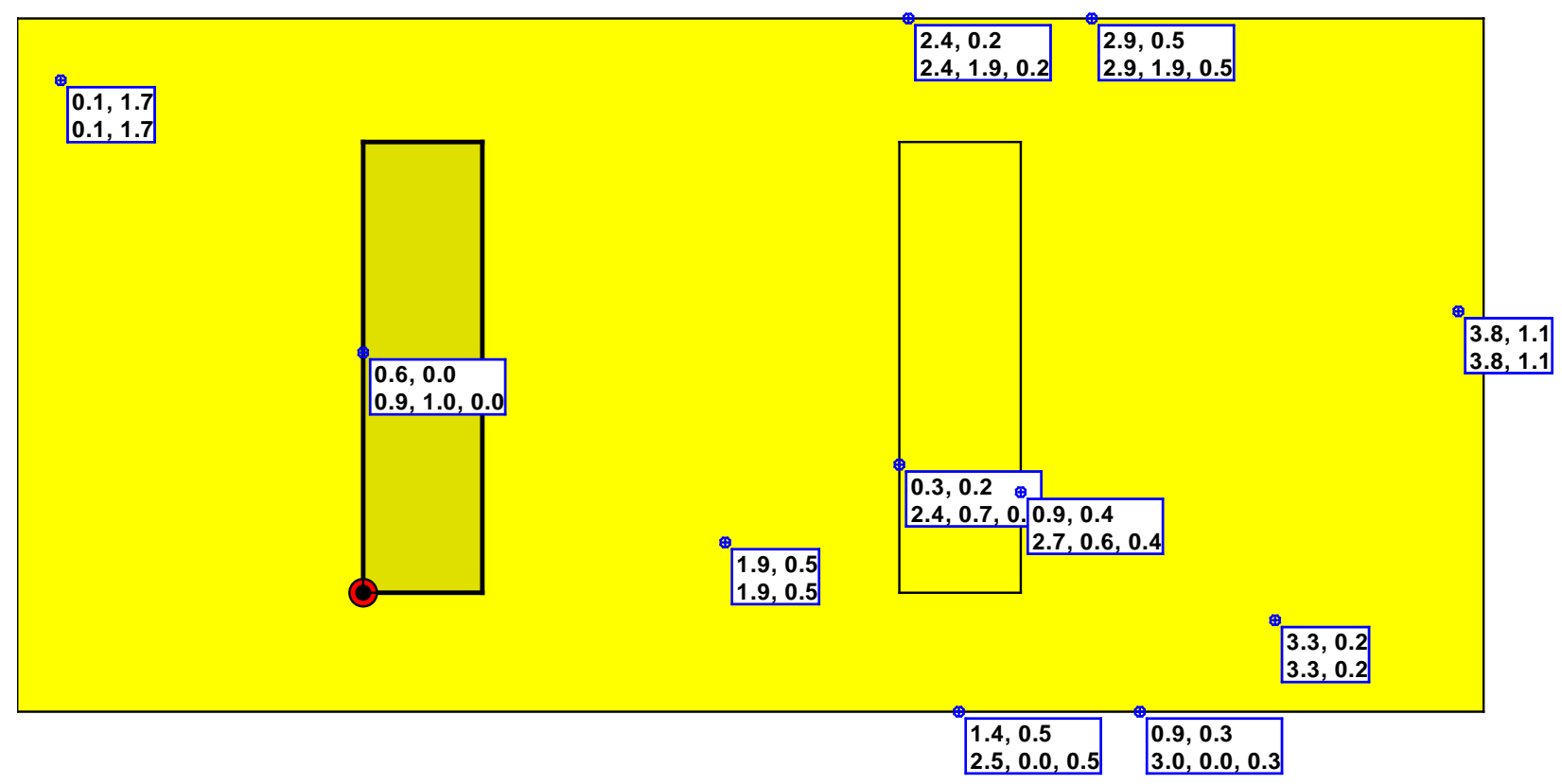

Fig. A-11. Sampling and Direct Measurement Locations for the Building 3117A Slab 


\begin{tabular}{|l|c|c|c|c|c|c|}
\hline \multicolumn{7}{|c|}{ Table A-4. Radionuclide Surface Activity Measurements for the } \\
Central Campus Building 3117A Slab \\
Oak Ridge National Laboratory \\
Oak Ridge, Tennessee
\end{tabular}


BUILDING 3119 SLAB 


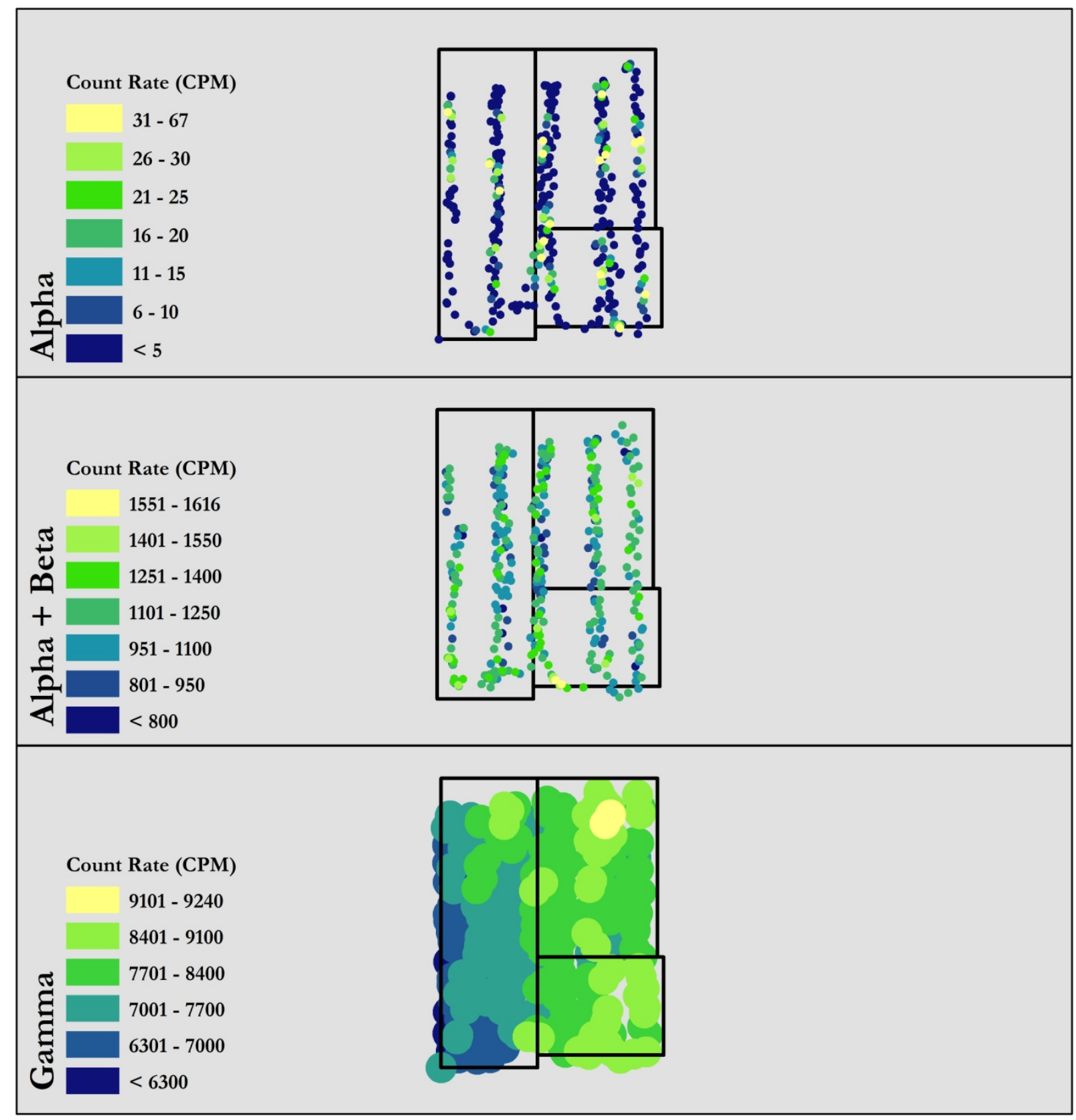

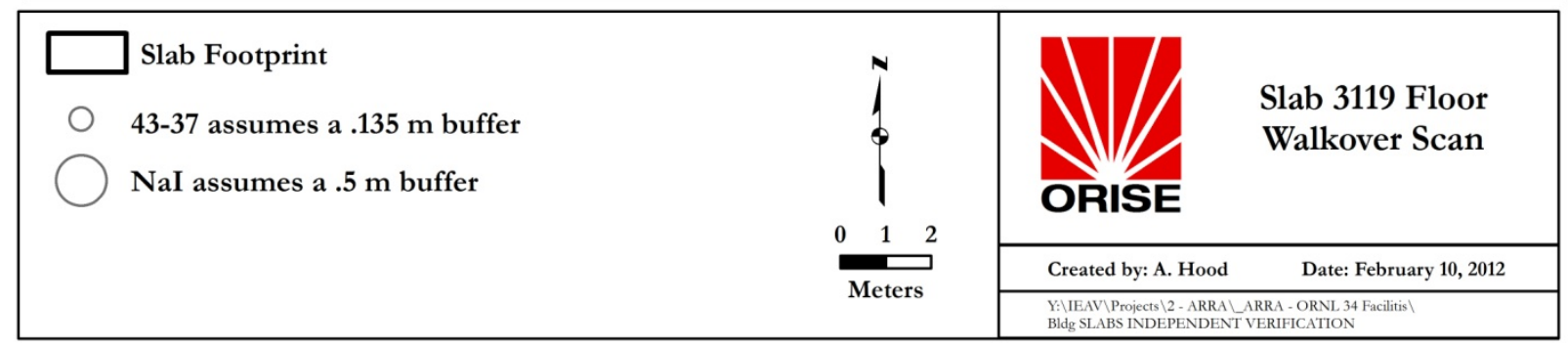

Fig. A-12. Surface Radiation Scans for the Building 3119 Slab 


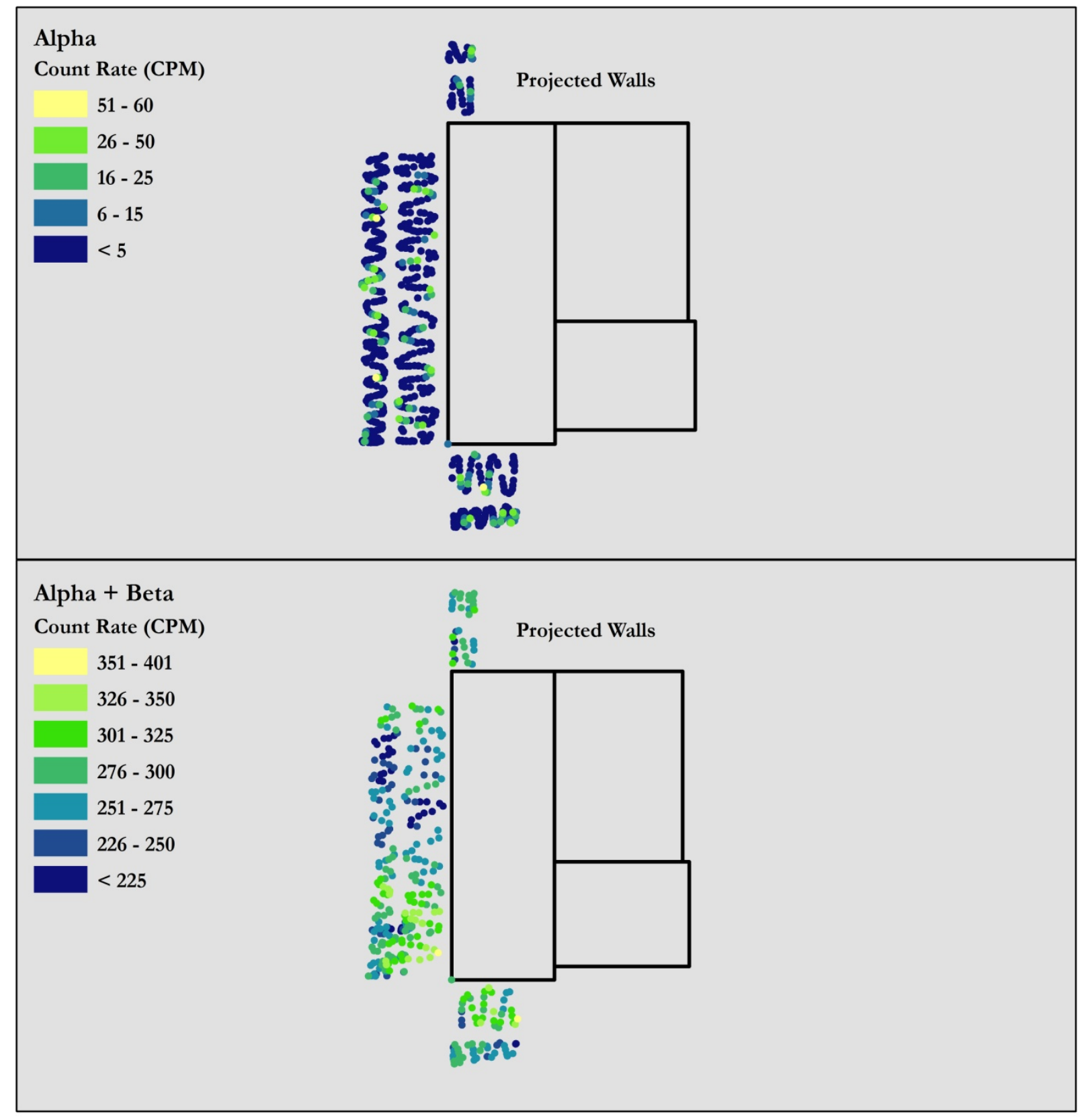

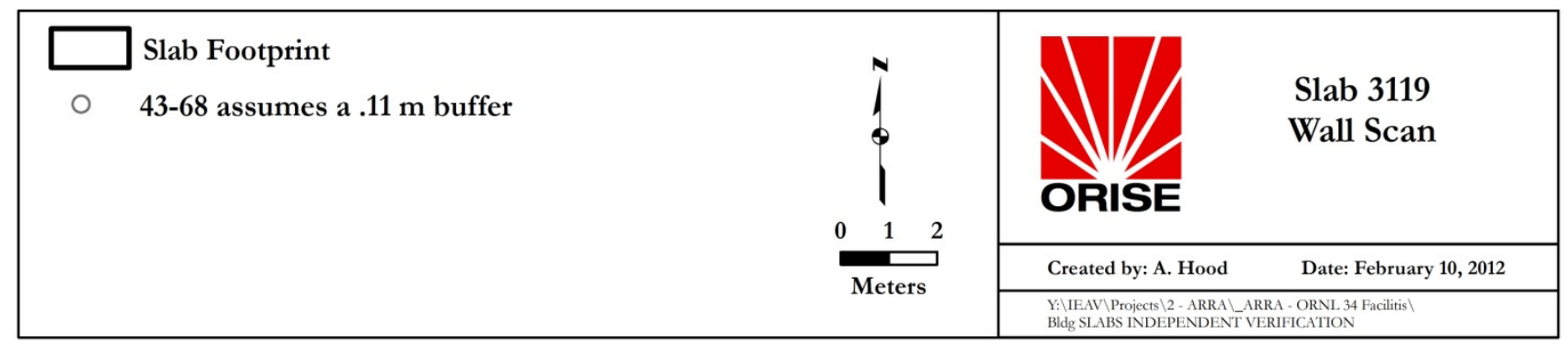

Fig. A-13. Surface Radiation Scans for the Building 3119 Slab 


\begin{tabular}{|c|c|c|c|c|c|c|}
\hline \multicolumn{7}{|c|}{$\begin{array}{c}\text { Building 3119 Slab Gamma Q-Q Plot } \\
\text { Summary Statistics for Raw Full Dataset }\end{array}$} \\
\hline Variable & NumObs & Minimum & Maximum & Mean & Median & SD \\
\hline Alpha Floor & 371 & 0 & 67 & 6.8 & 1 & 0 \\
\hline Alpha Wall & 760 & 0 & 60 & 1,106 & 1107 \\
\hline Alpha-plus-Beta Floor & 368 & 734 & 1,616 & 271 & 161.9 \\
\hline Alpha-plus-Beta Wall & 537 & 172 & 401 & 35.48 \\
\hline
\end{tabular}

Building 3119: Multiple Q-Q Plots

for Alpha and Alpha + Beta

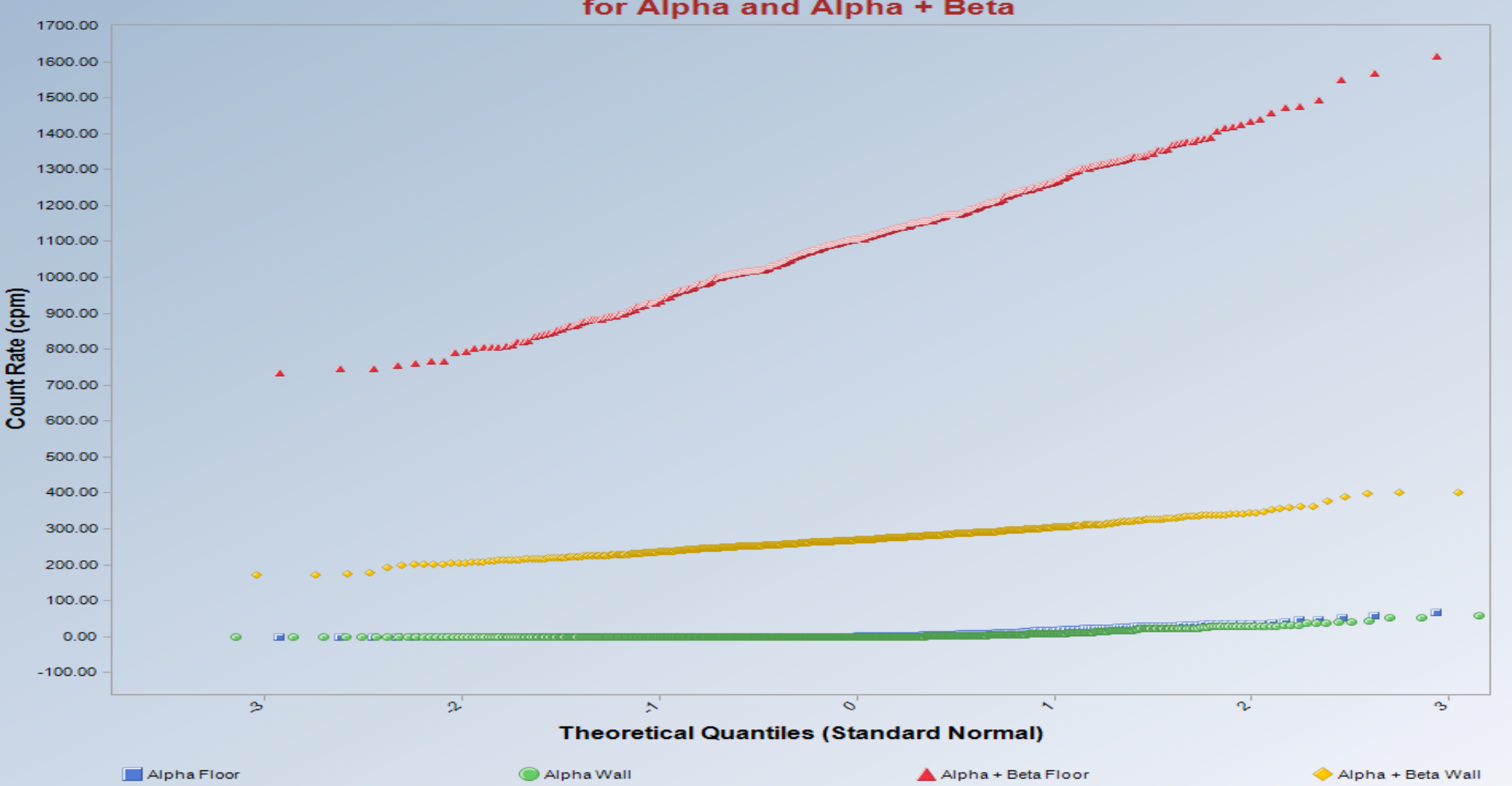

Fig. A-14. Alpha and Alpha-plus-Beta Scans Q-Plot for the Building 3119 Slab and Remaining Walls 


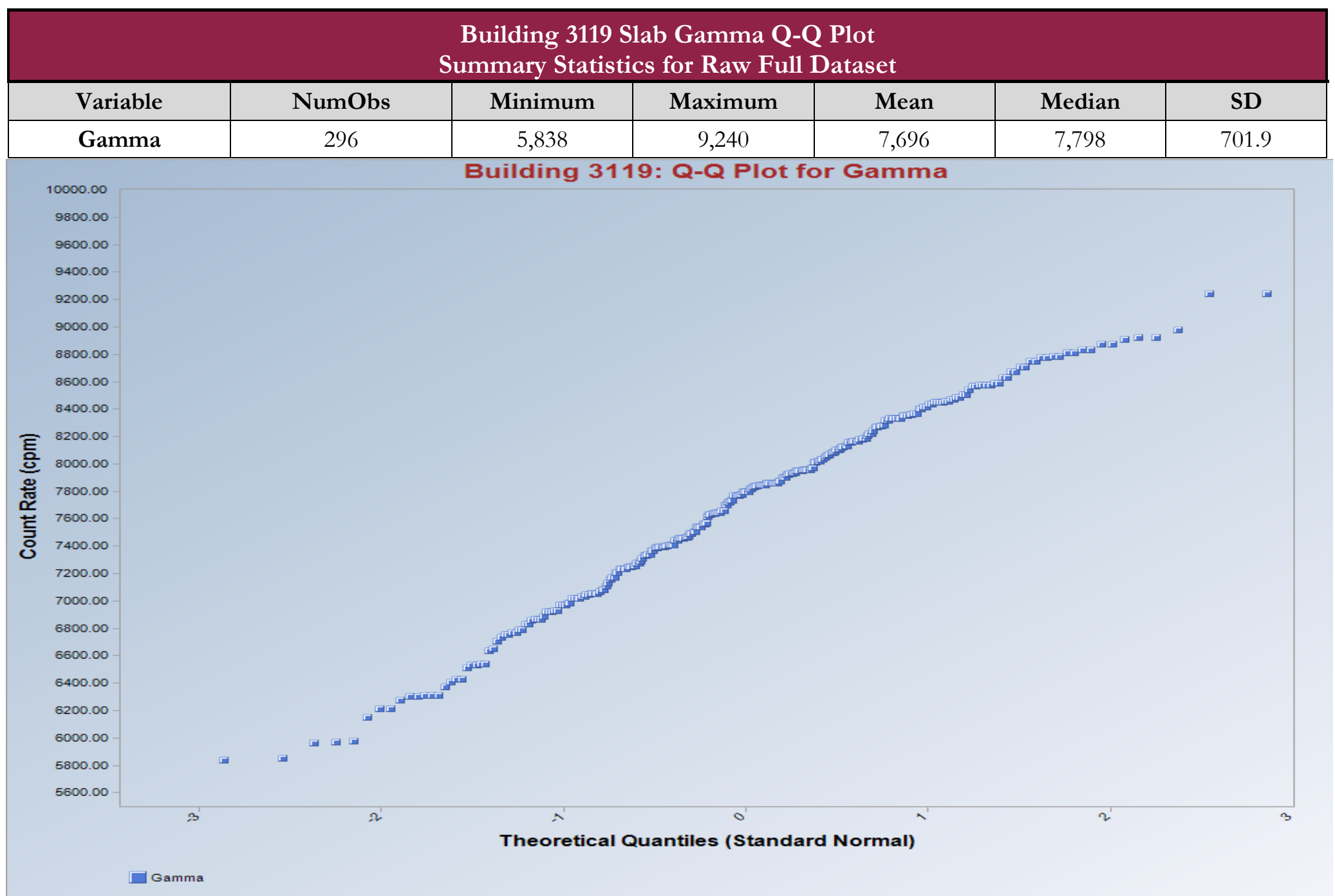

Fig. A-15. Gamma Scan Q-Plot for the Building 3119 Slab 


\section{9}

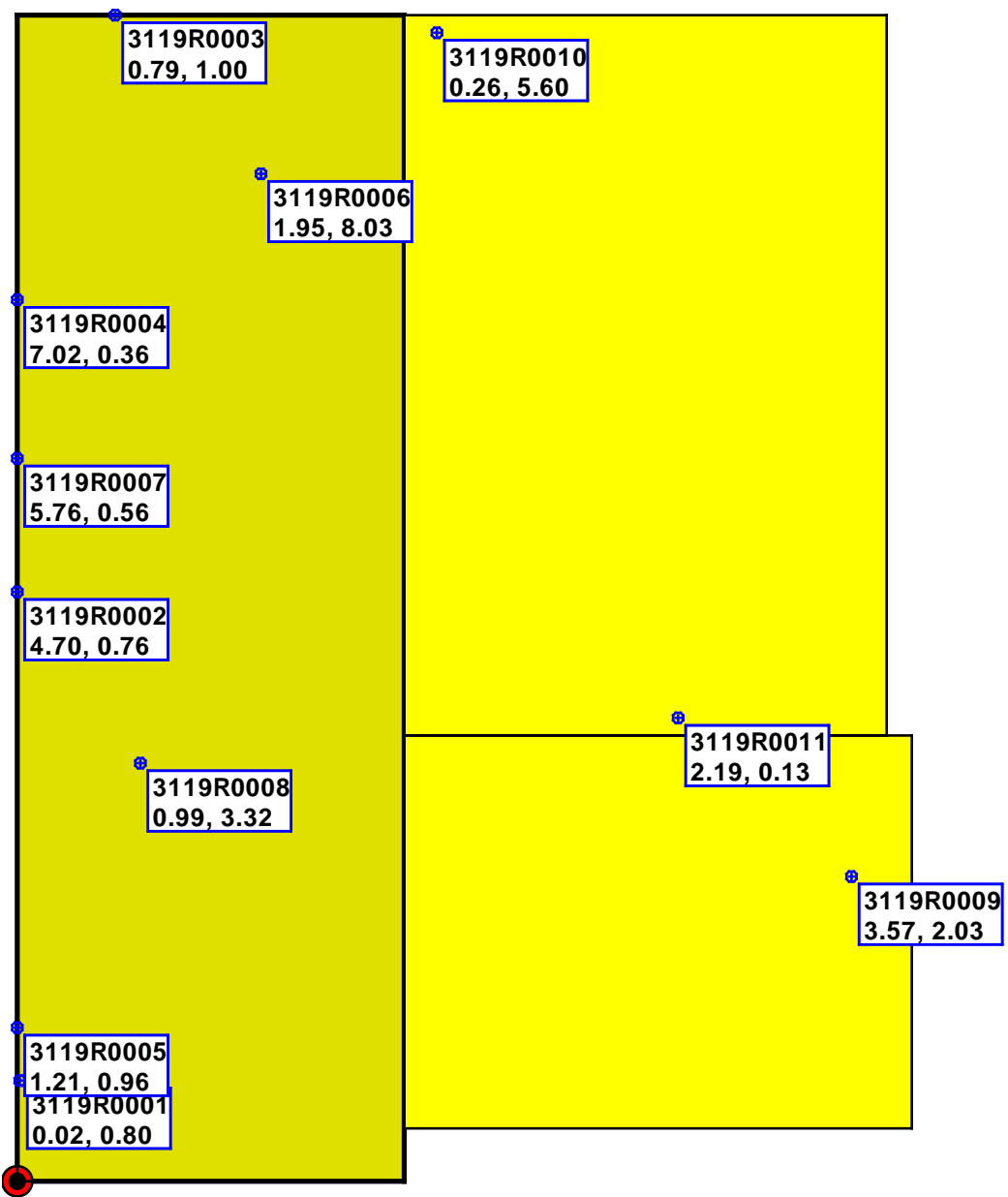

Fig. A-16. Sampling and Direct Measurement Locations for the Building 3119 Slab and Remaining Walls 


\begin{tabular}{|c|c|c|c|c|c|c|}
\hline \multicolumn{7}{|c|}{ Table A-5. Radionuclide Surface Activity Measurements for the } \\
Central Campus Building 3119 Slab \\
Oak Ridge National Laboratory \\
Oak Ridge, Tennessee
\end{tabular}


BUILDING 3503 SLAB 


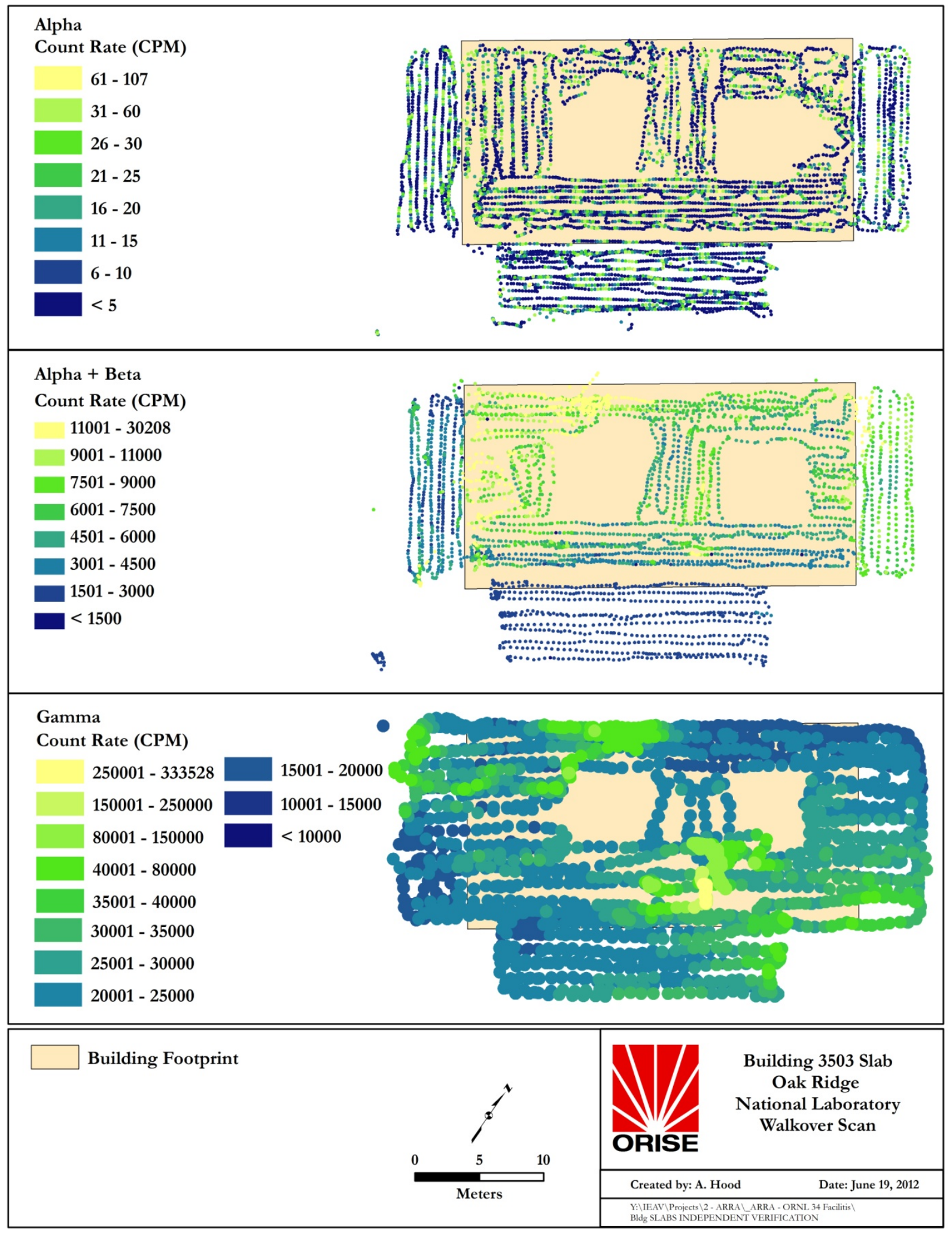

Fig. A-17. Surface Radiation Scans for the Building 3503 
Building 3503 Slab Alpha and Alpha-plus-Beta Q Plot Summary Statistics for Raw Full Dataset

\begin{tabular}{|c|c|c|c|c|c|c|}
\hline Variable & NumObs & Min & Max & Mean & Median & SD \\
\hline Alpha & 5,761 & 0 & 107 & 11 & 5 & 14 \\
\hline Alpha-plus-Beta & 4,317 & 0 & 30,208 & 6,152 & 5,490 & 3,729 \\
\hline
\end{tabular}

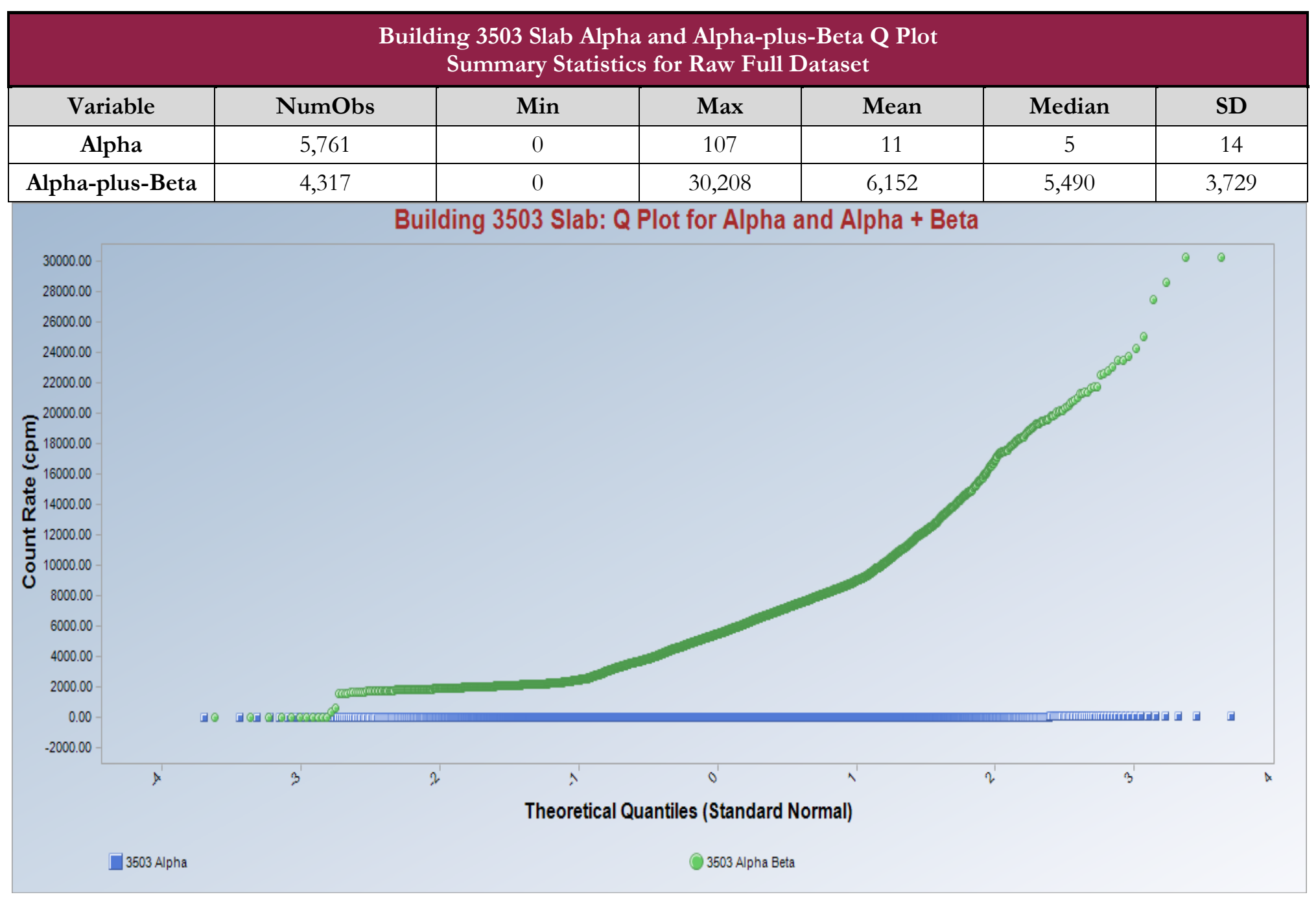

Fig. A-18. Alpha and Alpha-plus-Beta Scans Q-Plot for the Building 3503 Slab 


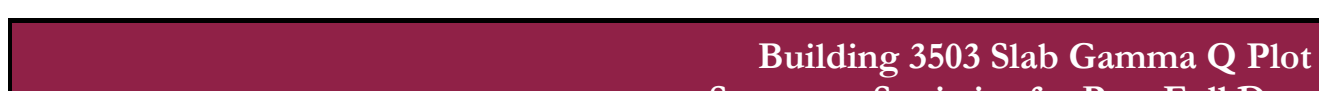

Summary Statistics for Raw Full Dataset

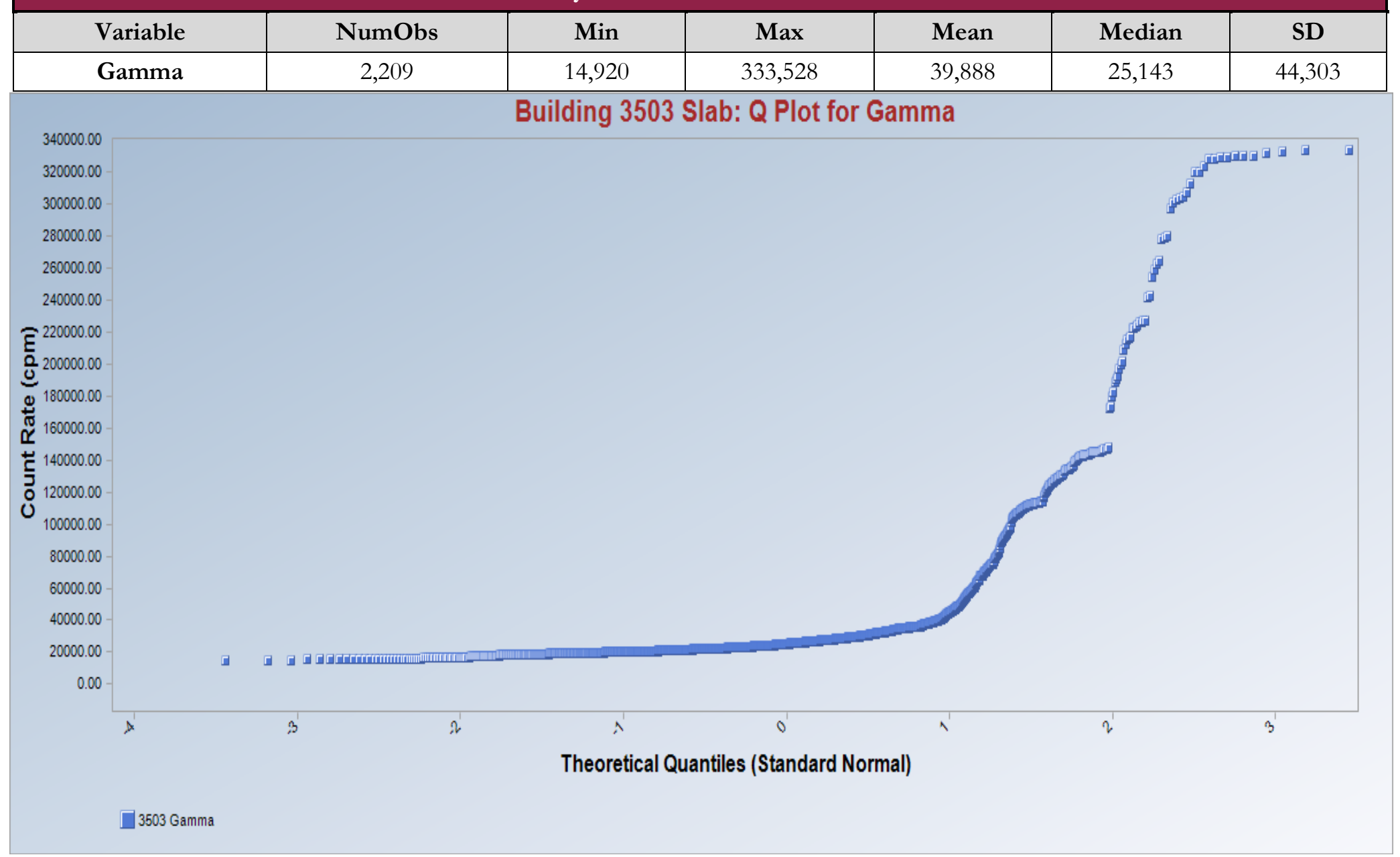

Fig. A-19. Gamma Q-Plot for the Building 3503 Slab 


\section{Building 3503}

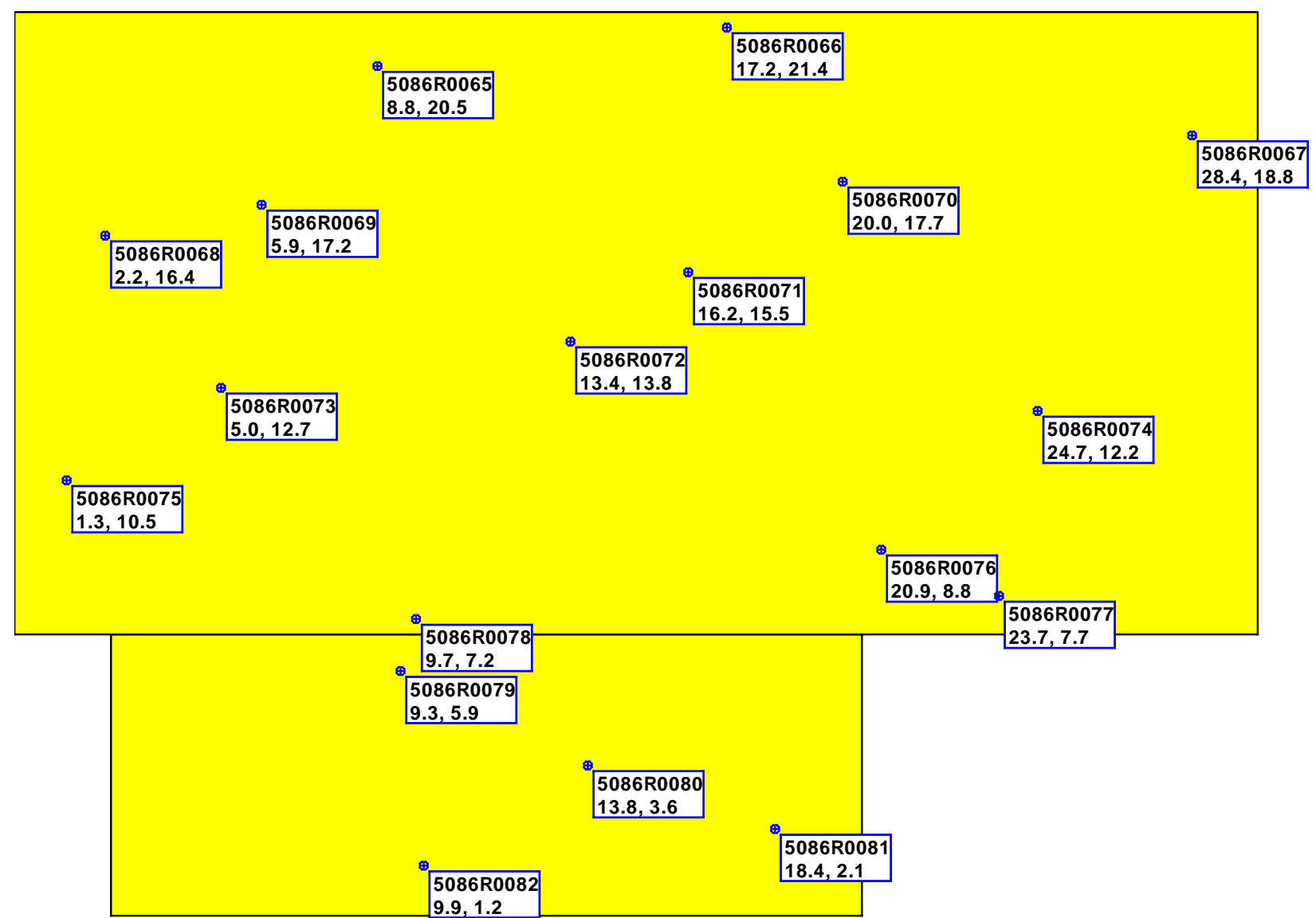

Fig. A-20. Sampling and Direct Measurement Locations for the Building 3503 Slab 


\begin{tabular}{|c|c|c|c|c|c|c|}
\hline \multicolumn{7}{|c|}{$\begin{array}{c}\text { Table A-6. Radionuclide Activities for the } \\
\text { Southeast Laboratory Complex Building } 3503 \text { Slab } \\
\text { Oak Ridge National Laboratory } \\
\text { Oak Ridge, Tennessee }\end{array}$} \\
\hline \multirow{3}{*}{$\begin{array}{l}\text { Measurement } \\
\text { Location/ } \\
\text { Sample ID }\end{array}$} & \multicolumn{4}{|c|}{ Total Activity } & \multirow{2}{*}{\multicolumn{2}{|c|}{$\begin{array}{l}\text { Removable Activity } \\
\text { Gross Alpha \& Beta }\end{array}$}} \\
\hline & \multicolumn{2}{|c|}{ Alpha } & \multicolumn{2}{|c|}{ Alpha-plus-Beta } & & \\
\hline & $\begin{array}{l}\text { Gross } \\
\text { cpm }\end{array}$ & $\begin{array}{c}\text { Activity } \\
\left(\mathrm{dpm} / 100 \mathrm{~cm}^{2}\right)\end{array}$ & $\begin{array}{l}\text { Gross } \\
\text { cpm }\end{array}$ & $\begin{array}{c}\text { Activity } \\
\left(\mathrm{dpm} / 100 \mathrm{~cm}^{2}\right)\end{array}$ & $\begin{array}{c}\text { Alpha } \\
\text { Activity } \\
\left(\mathrm{dpm} / 100 \mathrm{~cm}^{2}\right)\end{array}$ & $\begin{array}{c}\text { Beta } \\
\text { Activity } \\
\left(\mathrm{dpm} / 100 \mathrm{~cm}^{2}\right)\end{array}$ \\
\hline \multicolumn{7}{|c|}{3503} \\
\hline 5086R0065 & 4 & 8 & 1,299 & 2,900 & 0 & 0 \\
\hline 5086R0066 & 2 & -8 & 431 & 330 & 0 & 0 \\
\hline 5086R0067 & 3 & 0 & 431 & 330 & 5 & 2 \\
\hline 5086R0068 & 8 & 41 & 509 & 560 & 1 & 0 \\
\hline 5086R0069 & 8 & 41 & 495 & 520 & 6 & 2 \\
\hline 5086R0070 & 5 & 16 & 476 & 460 & 0 & 2 \\
\hline 5086R0071 & 10 & 57 & 501 & 530 & 0 & 0 \\
\hline 5086R0072 & 2 & -8 & 581 & 770 & 1 & 2 \\
\hline 5086R0073 & 16 & 110 & 514 & 570 & 0 & 0 \\
\hline 5086R0074 & 9 & 49 & 439 & 350 & 0 & 3 \\
\hline 5086R0075 & 5 & 16 & 449 & 380 & 0 & 0 \\
\hline 5086R0076 & 2 & -8 & 604 & 840 & 1 & 0 \\
\hline 5086R0077 & 4 & 8 & 495 & 520 & 0 & 0 \\
\hline 5086R0078 & 3 & 0 & 458 & 410 & 0 & 0 \\
\hline 5086R0079 & 10 & 57 & 522 & 600 & 0 & 0 \\
\hline 5086R0080 & 5 & 16 & 554 & 690 & 1 & 2 \\
\hline 5086R0081 & 3 & 0 & 554 & 690 & 1 & 0 \\
\hline 5086R0082 & 3 & 0 & 488 & 500 & 0 & 2 \\
\hline 5086R0133 & 5 & 16 & 4,333 & 12,000 & 0 & 2 \\
\hline
\end{tabular}




\section{BUILDING 3504 SLAB}




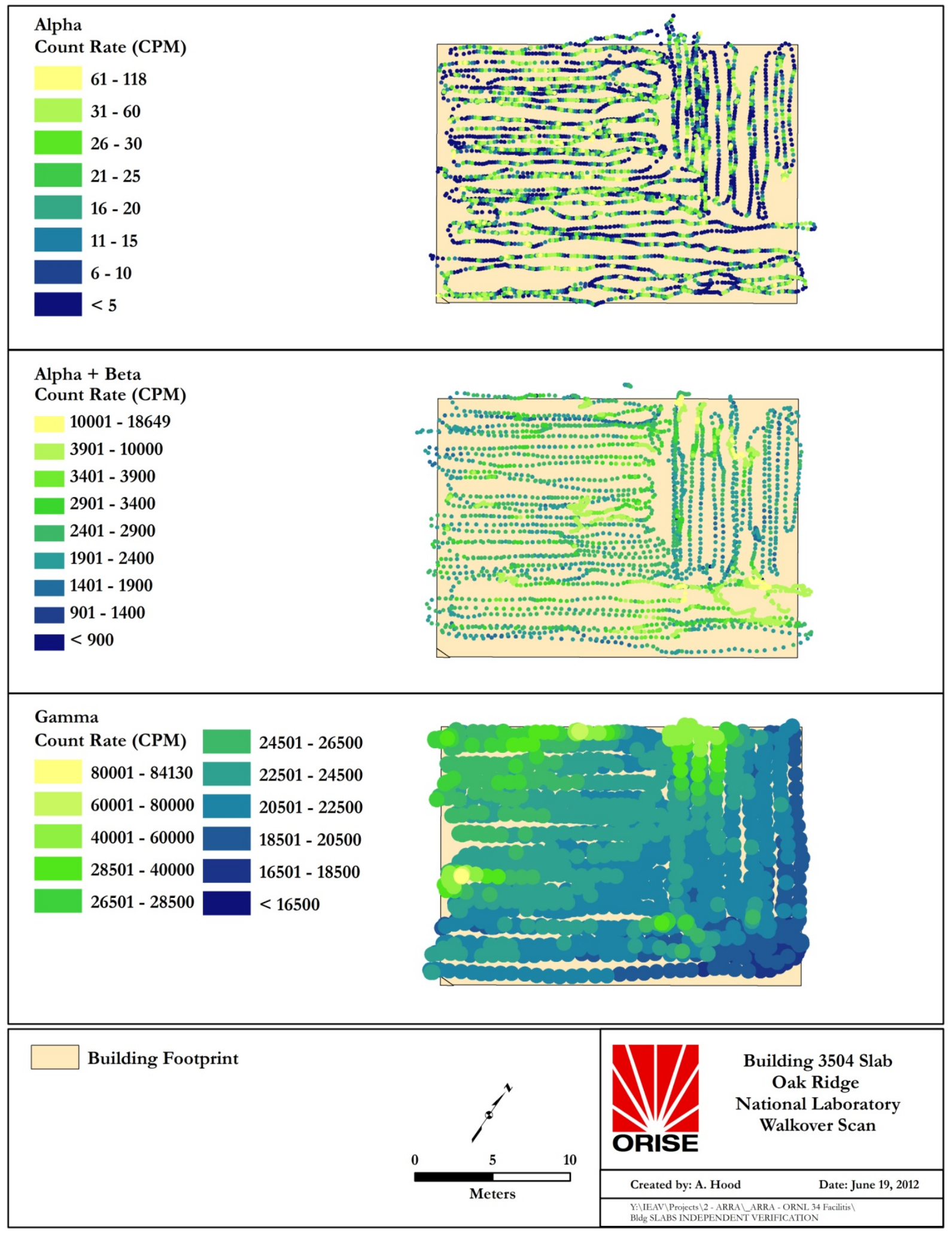

Fig. A-21. Surface Radiation Scans for the Building 3504 Slab 
Building 3504 Slab Alpha and Alpha-plus-Beta Q Plot Summary Statistics for Raw Full Dataset

\begin{tabular}{|c|c|c|c|c|c|c|}
\hline Variable & NumObs & Min & Max & Mean & Median & SD \\
\hline Alpha & 4,147 & 0 & 118 & 17 & 12 & 18 \\
\hline Alpha-plus-Beta & 3,439 & 0 & 18,649 & 3,749 & 2,704 & 2,722 \\
\hline
\end{tabular}

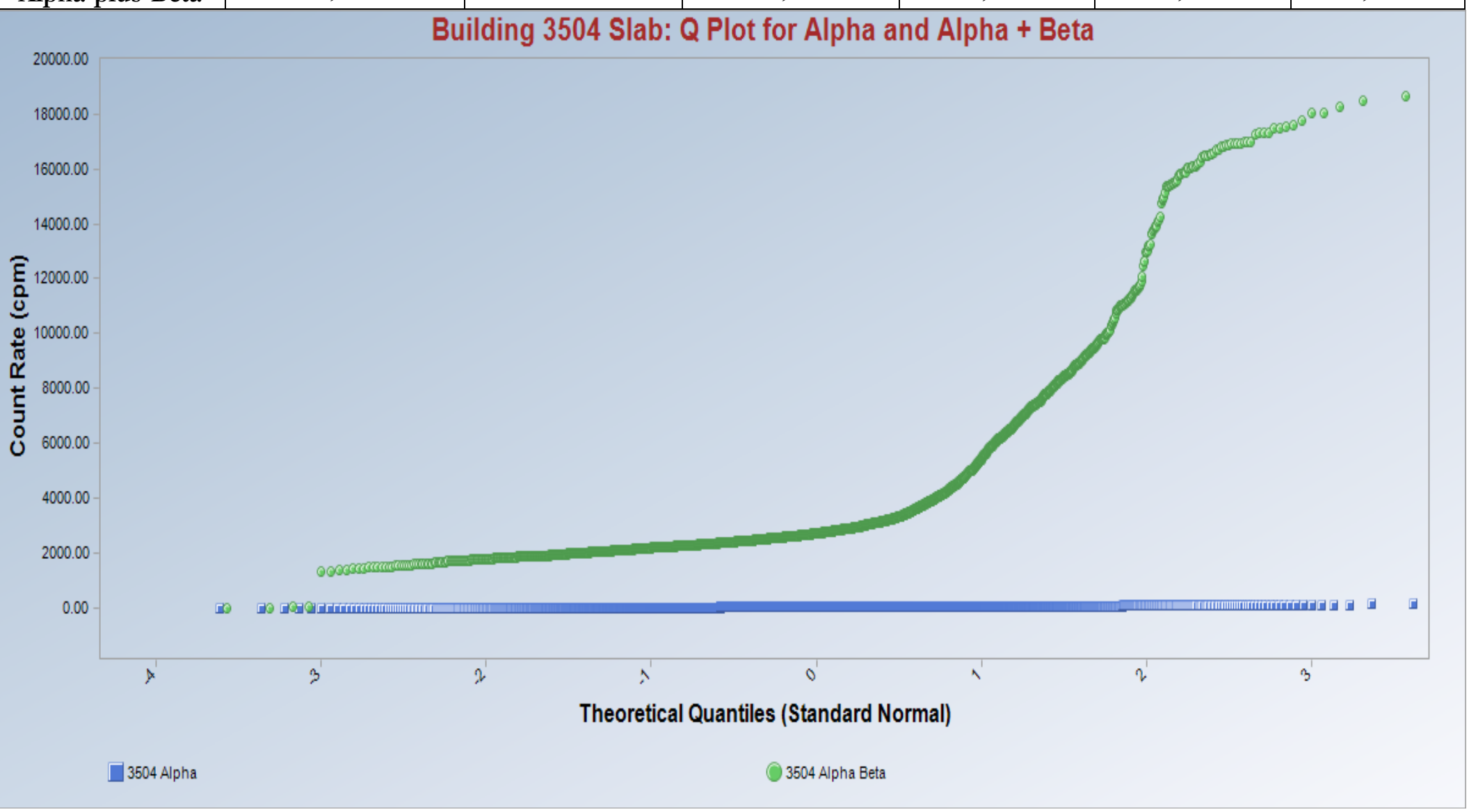

Fig. A-22. Alpha and Alpha Plus Beta Scan Q-Plot for the Building 3504 Slab 
Building 3504 Slab Gamma Q Plot

Summary Statistics for Raw Full Dataset

\begin{tabular}{|c|c|c|c|c|c|c|}
\hline Variable & NumObs & Min & Max & Mean & Median & SD \\
\hline Gamma & 1,243 & 14,567 & 84,130 & 23,974 & 22,501 & 6,851 \\
\hline
\end{tabular}

90000.00

Building 3504 Slab: Q Plot for Gamma

80000.00

70000.00

E 60000.00

은

总 50000.00

$\stackrel{10}{12}$

节

O

30000.00

20000.00

10000.00

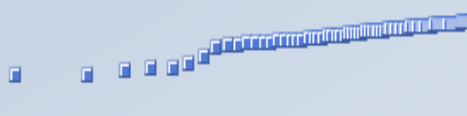

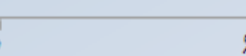

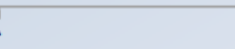

0

$\eta$

Theoretical Quantiles (Standard Normal)

Fig. A-23. Gamma Scan Q-Plot for the Building 3504 Slab 


\section{4}

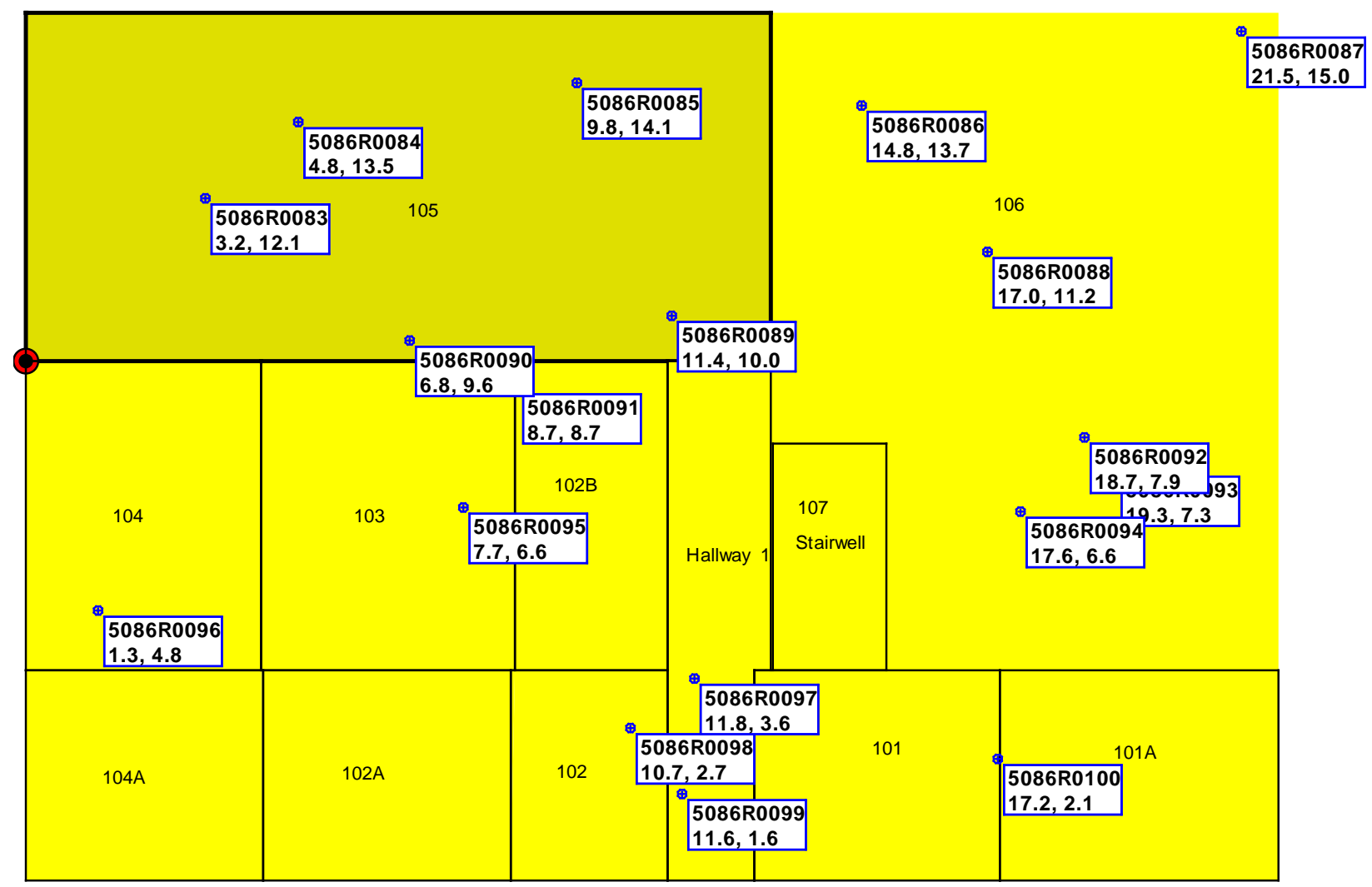

Fig. A-24. Sampling and Direct Measurement Locations for the Building 3504 Slab 


\begin{tabular}{|c|c|c|c|c|c|c|}
\hline \multicolumn{7}{|c|}{$\begin{array}{c}\text { Table A-7. Radionuclide Activities for the } \\
\text { Southeast Laboratory Complex Building } 3504 \text { Slab } \\
\text { Oak Ridge National Laboratory } \\
\text { Oak Ridge, Tennessee }\end{array}$} \\
\hline \multirow{3}{*}{$\begin{array}{l}\text { Measurement } \\
\text { Location/ } \\
\text { Sample ID }\end{array}$} & \multicolumn{4}{|c|}{ Total Activity } & \multirow{2}{*}{\multicolumn{2}{|c|}{$\begin{array}{l}\text { Removable Activity } \\
\text { Gross Alpha \& Beta }\end{array}$}} \\
\hline & \multicolumn{2}{|c|}{ Alpha } & \multicolumn{2}{|c|}{ Alpha-plus-Beta } & & \\
\hline & $\begin{array}{l}\text { Gross } \\
\text { cpm }\end{array}$ & $\begin{array}{c}\text { Activity } \\
\left(\mathrm{dpm} / 100 \mathrm{~cm}^{2}\right)\end{array}$ & $\begin{array}{l}\text { Gross } \\
\text { cpm }\end{array}$ & $\begin{array}{c}\text { Activity } \\
\left(\mathrm{dpm} / 100 \mathrm{~cm}^{2}\right)\end{array}$ & $\begin{array}{c}\text { Alpha } \\
\text { Activity } \\
\left(\mathrm{dpm} / 100 \mathrm{~cm}^{2}\right)\end{array}$ & $\begin{array}{c}\text { Beta } \\
\text { Activity } \\
\left(\mathrm{dpm} / 100 \mathrm{~cm}^{2}\right)\end{array}$ \\
\hline 5086R0083 & 8 & 41 & 537 & 640 & 1 & 2 \\
\hline 5086R0084 & 16 & 110 & 755 & 1,300 & 1 & 1 \\
\hline 5086R0085 & 3 & 0 & 788 & 1,400 & 0 & 0 \\
\hline 5086R0086 & 7 & 33 & 652 & 980 & 0 & 2 \\
\hline 5086R0087 & 3 & 0 & 655 & 990 & 0 & 0 \\
\hline 5086R0088 & 14 & 90 & 580 & 770 & 0 & 3 \\
\hline 5086R0089 & 13 & 81 & 753 & 1,300 & 0 & 2 \\
\hline 5086R0090 & 11 & 65 & 594 & 810 & 0 & 0 \\
\hline 5086R0091 & 9 & 49 & 598 & 820 & 1 & 2 \\
\hline 5086R0092 & 3 & 0 & 473 & 450 & 0 & 0 \\
\hline 5086R0093 & 4 & 8 & 595 & 810 & 0 & 3 \\
\hline 5086R0094 & 7 & 33 & 591 & 800 & 0 & 5 \\
\hline 5086R0095 & 9 & 49 & 594 & 810 & 4 & 0 \\
\hline 5086R0096 & 9 & 49 & 809 & 1,400 & 0 & 0 \\
\hline 5086R0097 & 3 & 0 & 643 & 950 & 1 & 0 \\
\hline 5086R0098 & 11 & 65 & 1,049 & 2,100 & 1 & 0 \\
\hline 5086R0099 & 9 & 49 & 1,221 & 2,700 & 0 & 1 \\
\hline 5086R0100 & 8 & 41 & 580 & 770 & 0 & 4 \\
\hline 5086R0130 & 12 & 73 & 4,428 & 12,000 & 0 & 4 \\
\hline
\end{tabular}


BUILDING 3508 SLAB 


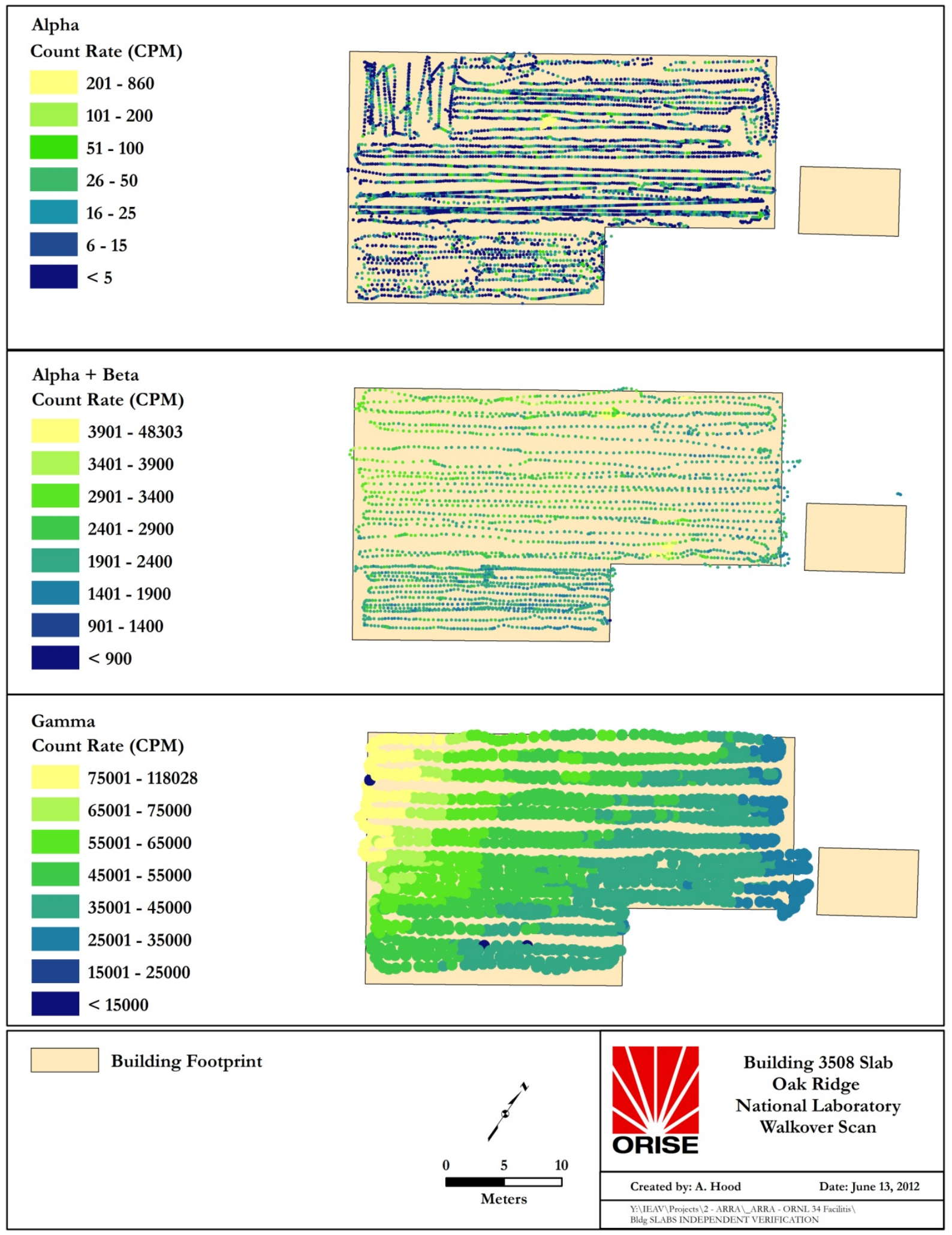

Fig. A-25. Surface Radiation Scans for the Building 3508 Slab 
Building 3508 Slab Alpha and Alpha-plus-Beta Q Plot Summary Statistics for Raw Full Dataset

\begin{tabular}{|c|c|c|c|c|c|c|}
\hline Variable & NumObs & Min & Max & Mean & Median & SD \\
\hline Alpha & 16,206 & 0 & 860 & 17 & 9 & 44 \\
\hline Alpha-plus-Beta & 3,155 & 0 & 48,303 & 3,280 & 2,279 & 5,762 \\
\hline
\end{tabular}

Building 3508 Slab: Q Plot for Alpha and Alpha + Beta

$$
48000.00
$$

44000.00

40000.00

36000.00

8000.00 .

4000.00 -

$-4000.00$

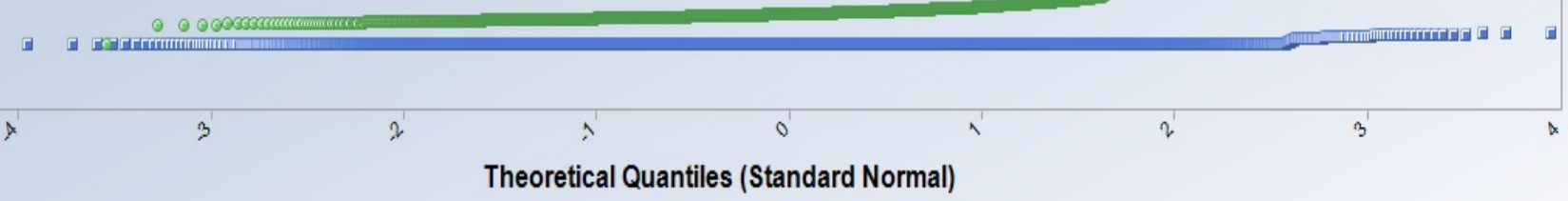

\3508 Alpha

3508 Alpha Beta

Fig. A-26. Alpha and Alpha Plus Beta Scan Q-Plot for the Building 3508 Slab 


\begin{tabular}{|c|c|c|c|c|c|c|}
\hline \multicolumn{7}{|c|}{$\begin{array}{c}\text { Building 3508 Slab Gamma Q Plot } \\
\text { Summary Statistics for Raw Full Dataset }\end{array}$} \\
\hline Variable & NumObs & Min & Max & Mean & Median & SD \\
\hline Gamma & 1,339 & 17,447 & 118,028 & 48,641 & 45,195 & 14,708 \\
\hline
\end{tabular}

120000.00 Building 3508: Q-Q Plot for Gamma

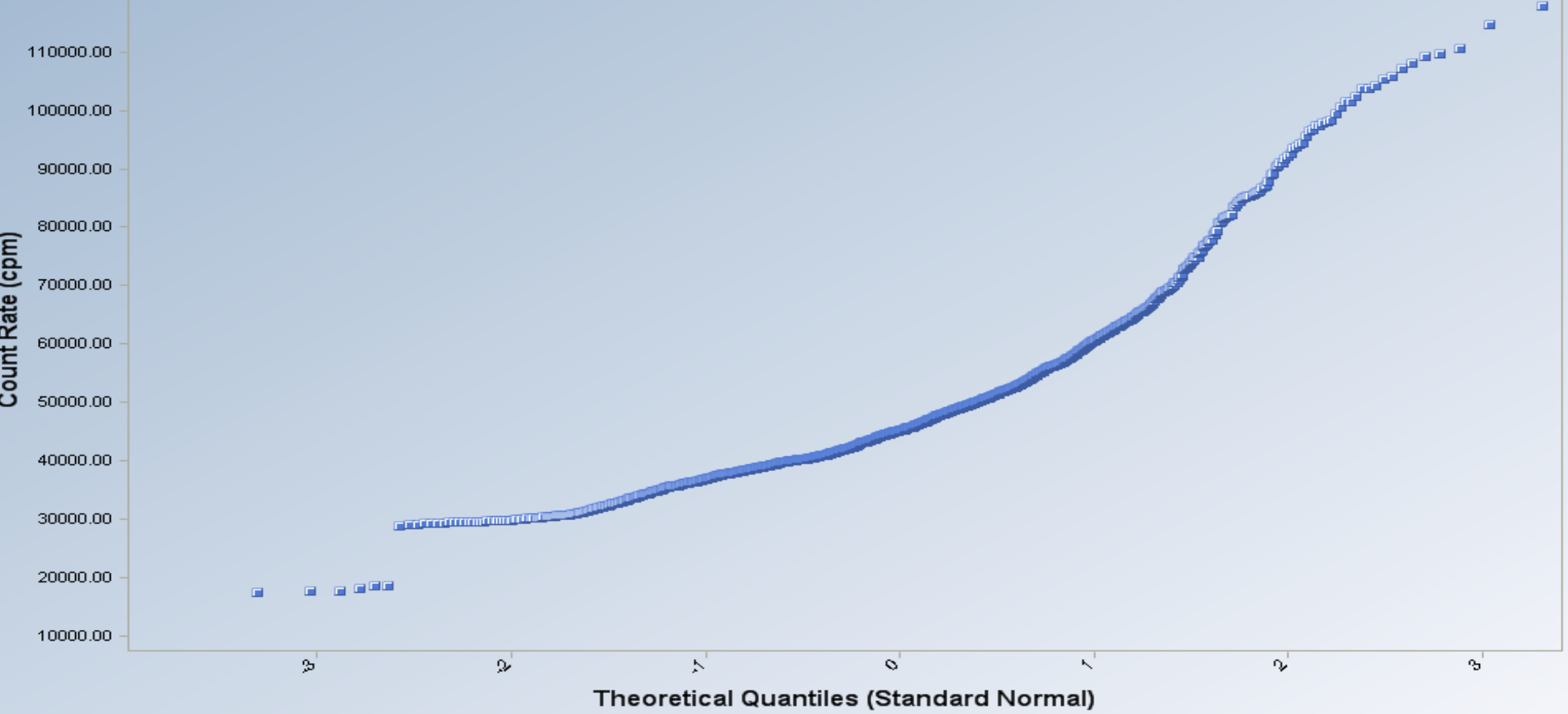

\3508 Gamma

Fig. A-27. Gamma Scan Q-Plot for the Building 3508 Slab 


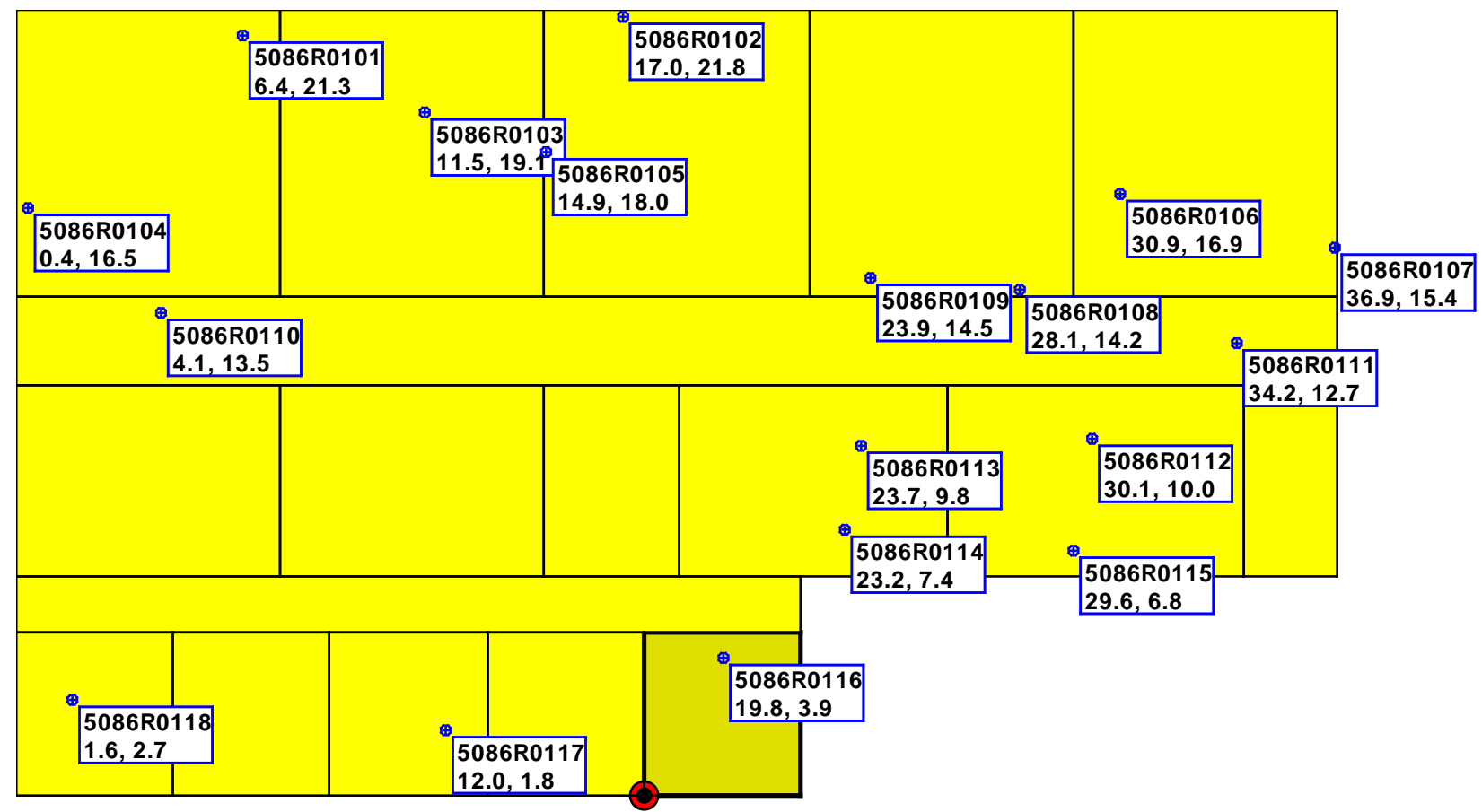

Fig. A-28. Sampling and Direct Measurement Locations for the Building 3508 Slab 


\begin{tabular}{|c|c|c|c|c|c|c|}
\hline \multicolumn{7}{|c|}{$\begin{array}{c}\text { Table A-8. Radionuclide Activities for the } \\
\text { Southeast Laboratory Complex Building } 3508 \text { Slab } \\
\text { Oak Ridge National Laboratory } \\
\text { Oak Ridge, Tennessee }\end{array}$} \\
\hline \multirow{3}{*}{$\begin{array}{l}\text { Measurement } \\
\text { Location/ } \\
\text { Sample ID }\end{array}$} & \multicolumn{4}{|c|}{ Total Activity } & \multirow{2}{*}{\multicolumn{2}{|c|}{$\begin{array}{l}\text { Removable Activity } \\
\text { Gross Alpha \& Beta }\end{array}$}} \\
\hline & \multicolumn{2}{|c|}{ Alpha } & \multicolumn{2}{|c|}{ Alpha-plus-Beta } & & \\
\hline & $\begin{array}{l}\text { Gross } \\
\text { cpm }\end{array}$ & $\begin{array}{c}\text { Activity } \\
\left(\mathrm{dpm} / 100 \mathrm{~cm}^{2}\right)\end{array}$ & $\begin{array}{l}\text { Gross } \\
\text { cpm }\end{array}$ & $\begin{array}{c}\text { Activity } \\
\left(\mathrm{dpm} / 100 \mathrm{~cm}^{2}\right)\end{array}$ & $\begin{array}{c}\text { Alpha } \\
\text { Activity } \\
\left(\mathrm{dpm} / 100 \mathrm{~cm}^{2}\right)\end{array}$ & $\begin{array}{c}\text { Beta } \\
\text { Activity } \\
\left(\mathrm{dpm} / 100 \mathrm{~cm}^{2}\right)\end{array}$ \\
\hline \multicolumn{7}{|c|}{3508 Slab } \\
\hline 5086R0101 & 6 & 24 & 663 & 1,000 & na & na \\
\hline 5086R0102 & 8 & 41 & 582 & 770 & na & na \\
\hline 5086R0103 & 6 & 24 & 610 & 860 & 1 & 2 \\
\hline 5086R0104 & 5 & 16 & 706 & 1,100 & na & na \\
\hline 5086R0105 & 14 & 90 & 809 & 1,400 & 0 & 4 \\
\hline 5086R0106 & 3 & 0 & 526 & 610 & na & na \\
\hline 5086R0107 & 5 & 16 & 550 & 680 & na & na \\
\hline 5086R0108 & 5 & 16 & 505 & 550 & na & na \\
\hline 5086R0109 & 2 & -8 & 490 & 500 & na & na \\
\hline 5086R0110 & 7 & 33 & 680 & 1,100 & 4 & 3 \\
\hline 5086R0111 & 5 & 16 & 557 & 700 & 4 & 3 \\
\hline 5086R0112 & 10 & 57 & 525 & 610 & 0 & 0 \\
\hline 5086R0113 & 5 & 16 & 554 & 690 & 1 & 4 \\
\hline 5086R0114 & 1 & -16 & 602 & 830 & 0 & 1 \\
\hline 5086R0115 & 7 & 33 & 517 & 580 & 1 & 3 \\
\hline 5086R0116 & 9 & 49 & 549 & 680 & 1 & 2 \\
\hline 5086R0117 & 15 & 98 & 603 & 830 & 1 & 2 \\
\hline 5086R0118 & 7 & 33 & 611 & 860 & 0 & 7 \\
\hline 5086R0131 & 62 & 480 & 33,113 & 96,000 & 0 & 0 \\
\hline 5086R0132 & 3,980 & 32,000 & 3,490 & 9,300 & 27 & 7 \\
\hline
\end{tabular}




\section{BUILDING 3541 SLAB}




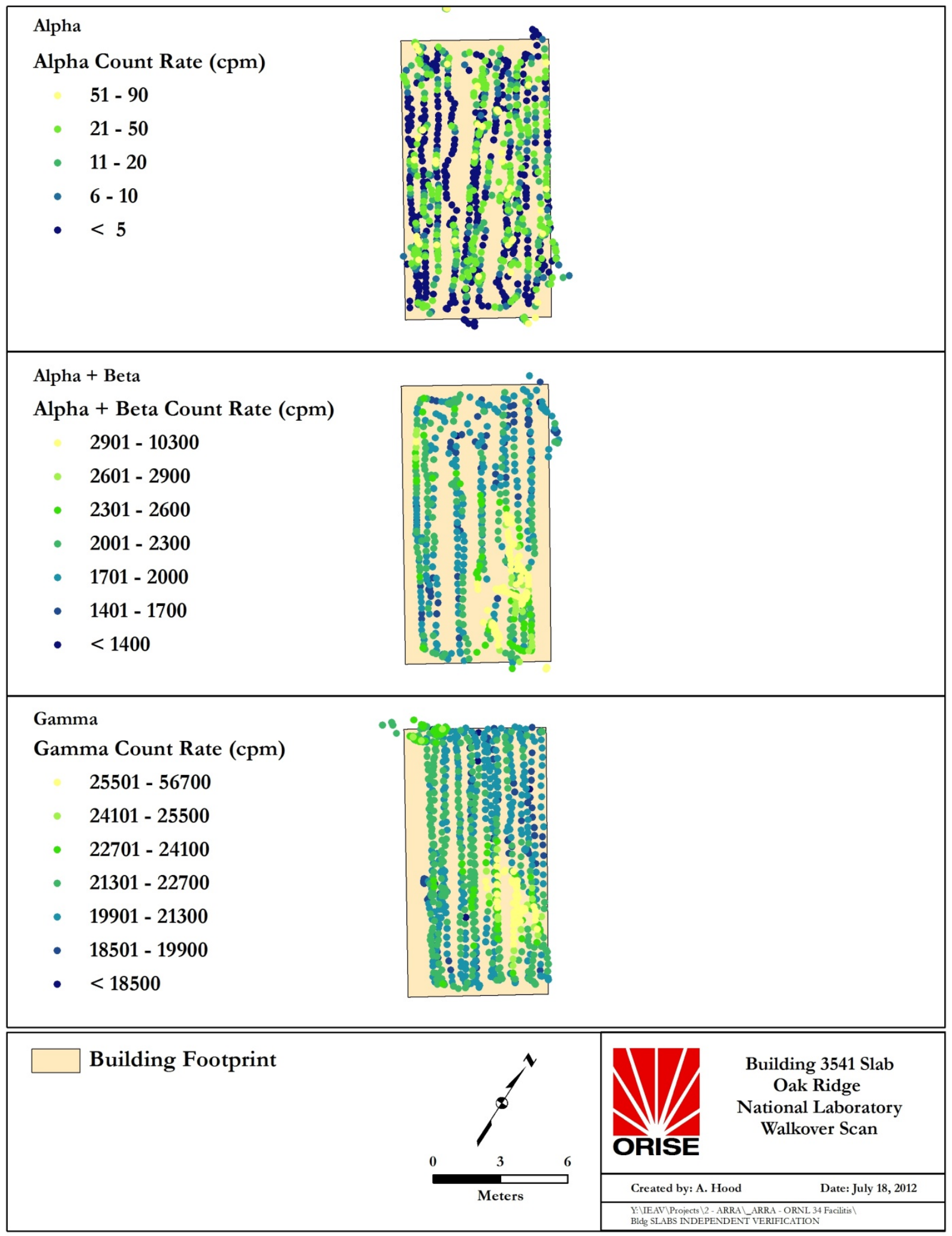

Fig. A-29. Surface Radiation Scans for the Building 3541 Slab 


\begin{tabular}{|c|c|c|c|c|c|c|}
\hline \multicolumn{7}{|c|}{$\begin{array}{c}\text { Building 3541 Slab Alpha and Alpha-plus-Beta Q Plot } \\
\text { Summary Statistics for Raw Full Dataset }\end{array}$} \\
\hline Variable & NumObs & Minimum & Maximum & Mean & Median & SD \\
\hline Alpha & 991 & 0 & 90 & 15.27 & 9 & 16.7 \\
\hline Alpha-plus-Beta & 716 & 0 & 10,230 & 2,639 & 2,036 & 1,682 \\
\hline
\end{tabular}

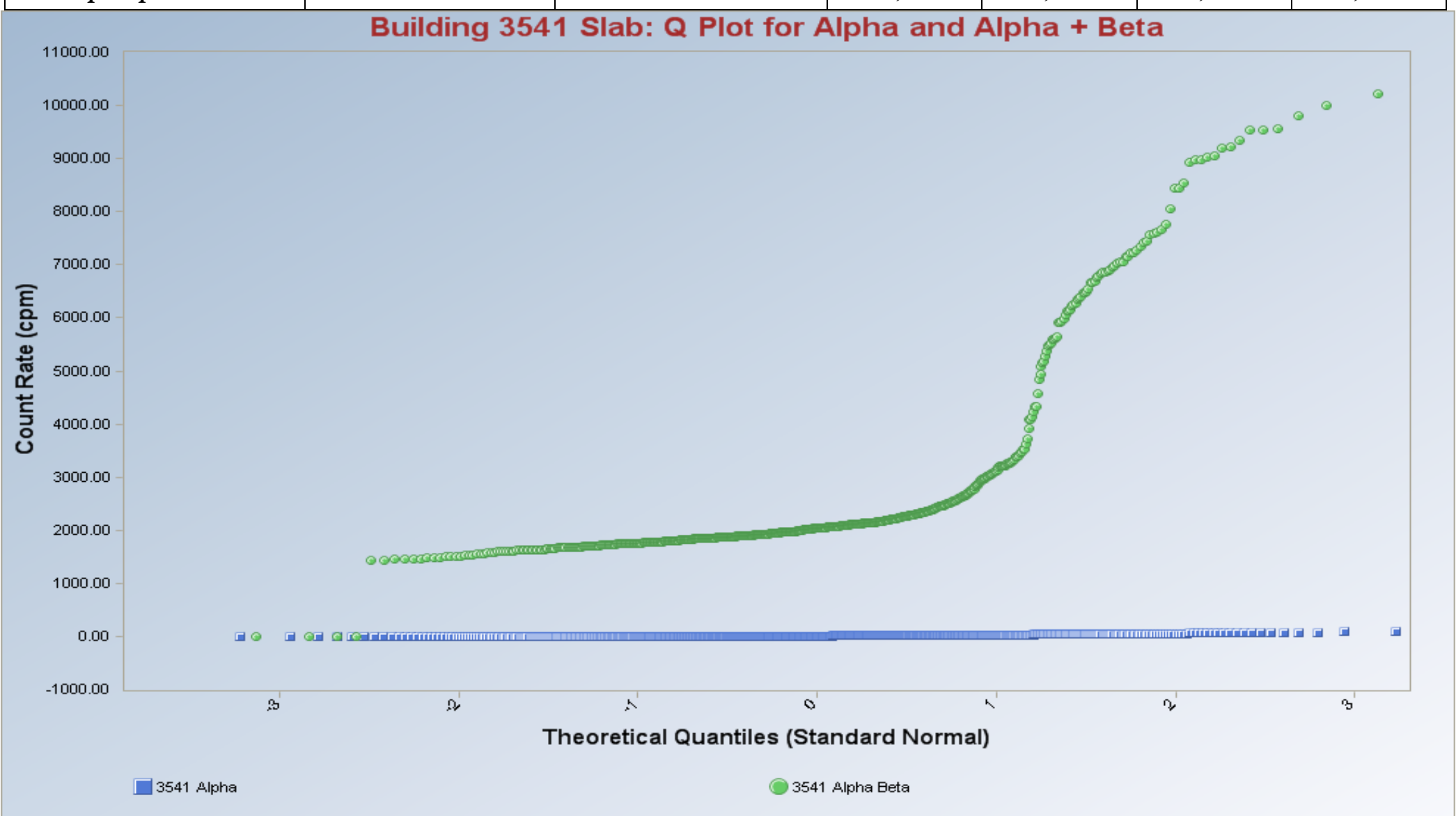

Fig. A-30. Alpha and Alpha-plus-Beta Scan Q-Plot for the Building 3541 Slab 


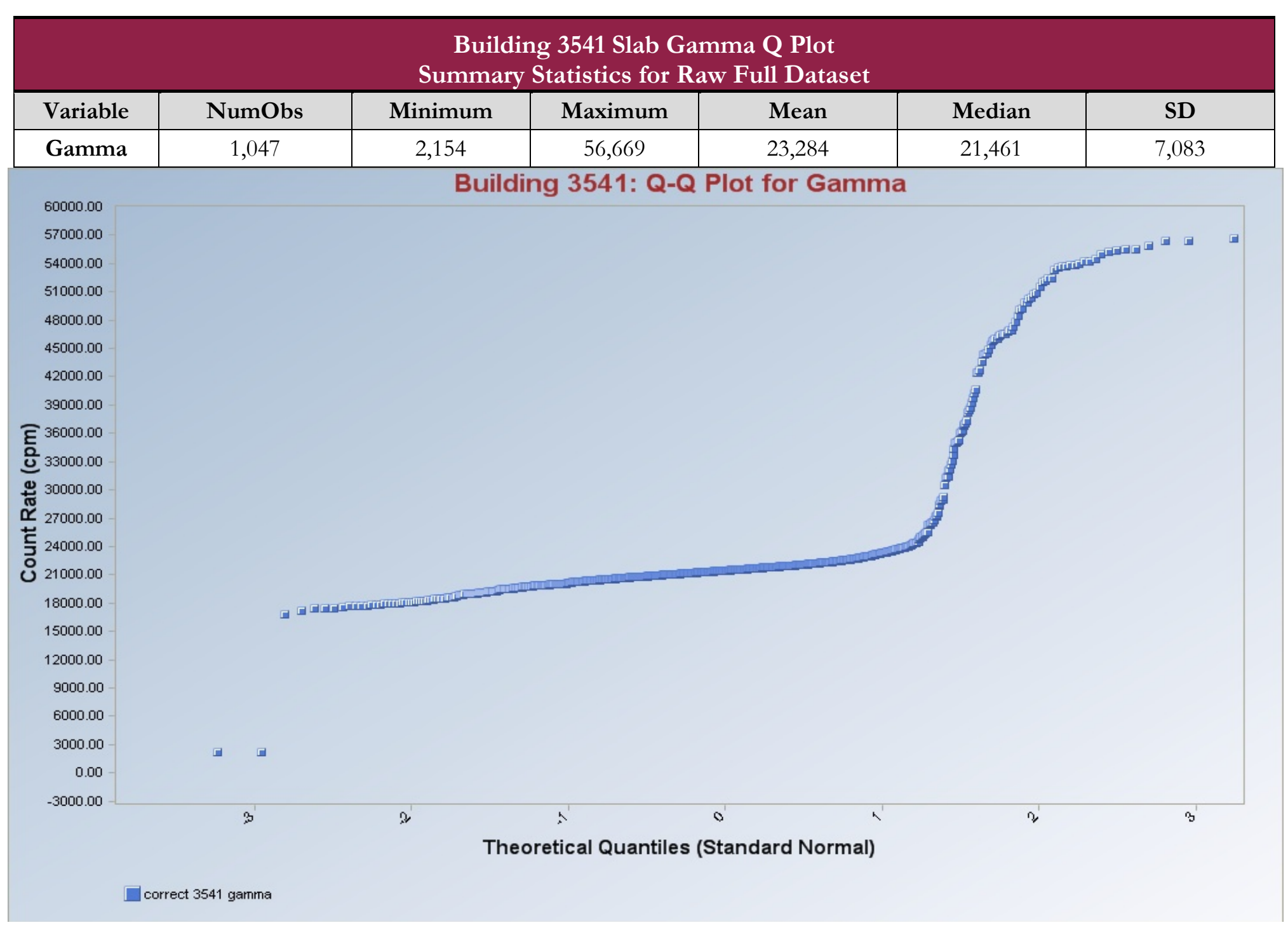

Fig. A-31. Gamma Scan Q-Plot for the Building 3541 Slab 


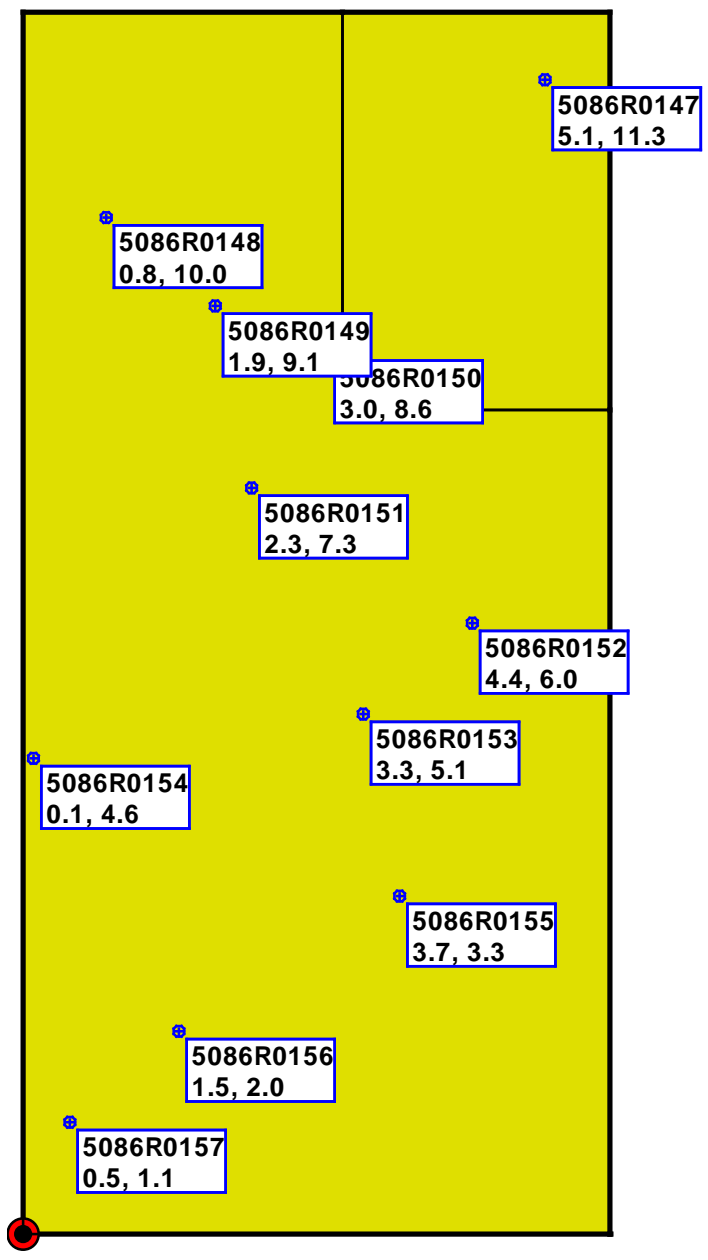

Fig. A-32. Sampling and Direct Measurement Locations for the Building 3541 Slab 


\begin{tabular}{|c|c|c|c|c|c|c|}
\hline \multicolumn{7}{|c|}{$\begin{array}{c}\text { Table A-9. Radionuclide Activities for the } \\
\text { Southeast Laboratory Complex Building } 3541 \text { Slab } \\
\text { Oak Ridge National Laboratory } \\
\text { Oak Ridge, Tennessee }\end{array}$} \\
\hline \multirow{3}{*}{$\begin{array}{l}\text { Measurement } \\
\text { Location/ } \\
\text { Sample ID }\end{array}$} & \multicolumn{4}{|c|}{ Total Activity } & \multirow{2}{*}{\multicolumn{2}{|c|}{$\begin{array}{l}\text { Removable Activity } \\
\text { Gross Alpha \& Beta }\end{array}$}} \\
\hline & \multicolumn{2}{|c|}{ Alpha } & \multicolumn{2}{|c|}{ Alpha-plus-Beta } & & \\
\hline & $\begin{array}{l}\text { Gross } \\
\text { cpm }\end{array}$ & $\begin{array}{c}\text { Activity } \\
\left(\mathrm{dpm} / 100 \mathrm{~cm}^{2}\right)\end{array}$ & $\begin{array}{l}\text { Gross } \\
\text { cpm }\end{array}$ & $\begin{array}{c}\text { Activity } \\
\left(\mathrm{dpm} / 100 \mathrm{~cm}^{2}\right)\end{array}$ & $\begin{array}{c}\text { Alpha } \\
\text { Activity } \\
\left(\mathrm{dpm} / 100 \mathrm{~cm}^{2}\right)\end{array}$ & $\begin{array}{c}\text { Beta } \\
\text { Activity } \\
\left(\mathrm{dpm} / 100 \mathrm{~cm}^{2}\right)\end{array}$ \\
\hline \multicolumn{7}{|c|}{3541 Slab } \\
\hline 5086R0147 & 3 & 0 & 508 & 560 & 0 & 3 \\
\hline 5086R0148 & 4 & 8 & 486 & 490 & 0 & 1 \\
\hline 5086R0149 & 3 & 0 & 447 & 380 & 1 & 0 \\
\hline 5086R0150 & 3 & 0 & 559 & 710 & 1 & 6 \\
\hline 5086R0151 & 3 & 0 & 514 & 570 & 1 & 4 \\
\hline 5086R0152 & 4 & 8 & 564 & 720 & 0 & 0 \\
\hline 5086R0153 & 3 & 0 & 528 & 610 & 1 & 3 \\
\hline 5086R0154 & 2 & -8 & 465 & 430 & 0 & 3 \\
\hline 5086R0155 & 4 & 8 & 504 & 540 & 3 & 0 \\
\hline 5086R0156 & 3 & 0 & 505 & 550 & 1 & 0 \\
\hline 5086R0157 & 6 & 24 & 530 & 620 & 0 & 0 \\
\hline
\end{tabular}


BUILDING 3543 SLAB 


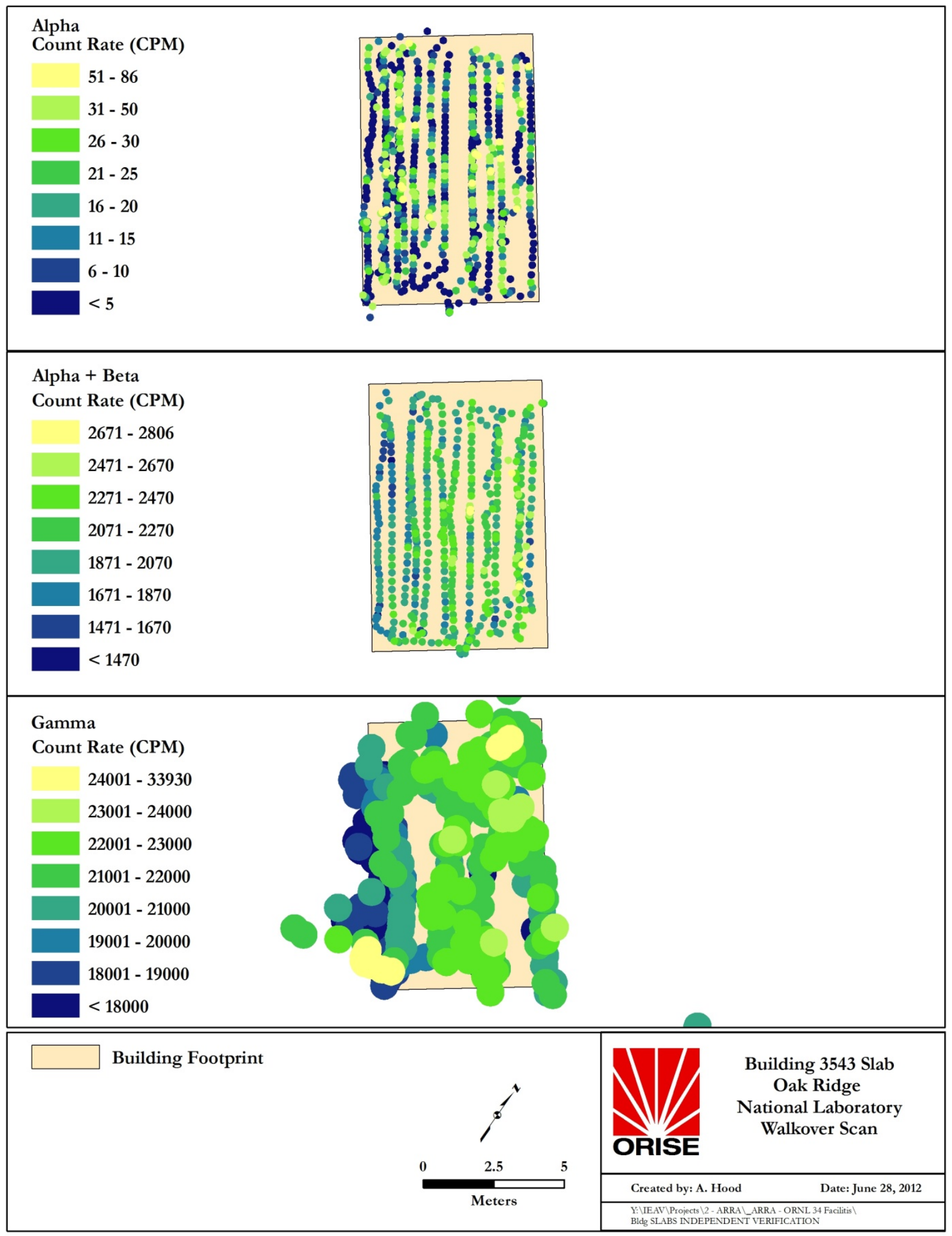

Fig. A-33. Surface Radiation Scans for the Building 3543 Slab 
Building 3543 Slab Alpha and Alpha-plus-Beta Q Plot Summary Statistics for Raw Full Dataset

\begin{tabular}{|c|c|c|c|c|c|c|}
\hline Variable & NumObs & Min & Max & Mean & Median & SD \\
\hline Alpha & 703 & 0 & 86 & 16 & 11 & 16 \\
\hline Alpha-plus-Beta & 573 & 160 & 2,806 & 2,072 & 2,079 & 239 \\
\hline
\end{tabular}

Building 3543 Slab: Q Plot for Alpha and Alpha + Beta

2800.00

2600.00

2400.00

2200.00

2000.00

등 1800.00

$\underbrace{}_{1600.00}$

荧 1400.00

ㄸ. 1200.00

독 1200.00

○े 1000.00

600.00

400.00

200.00

0.00

$-200.00$

3

2

Theoretical Quantiles (Standard Normal)

3541 Alpha Beta

Fig. A-34. Alpha and Alpha Plus Beta Scan Q-Plot for the Building 3543 Slab 


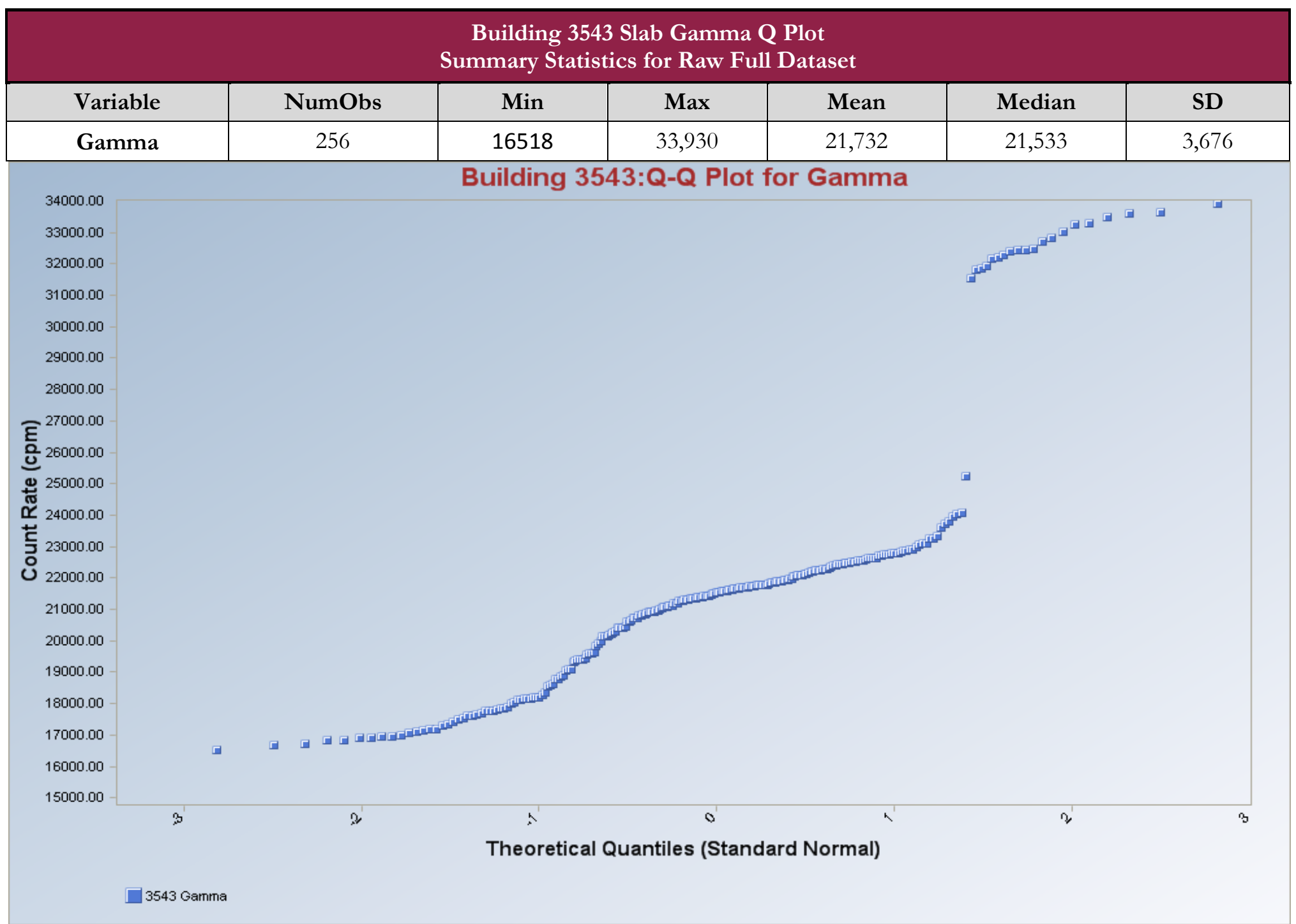

Fig. A-35. Gamma Scan Q-Plot for the Building 3543 Slab 


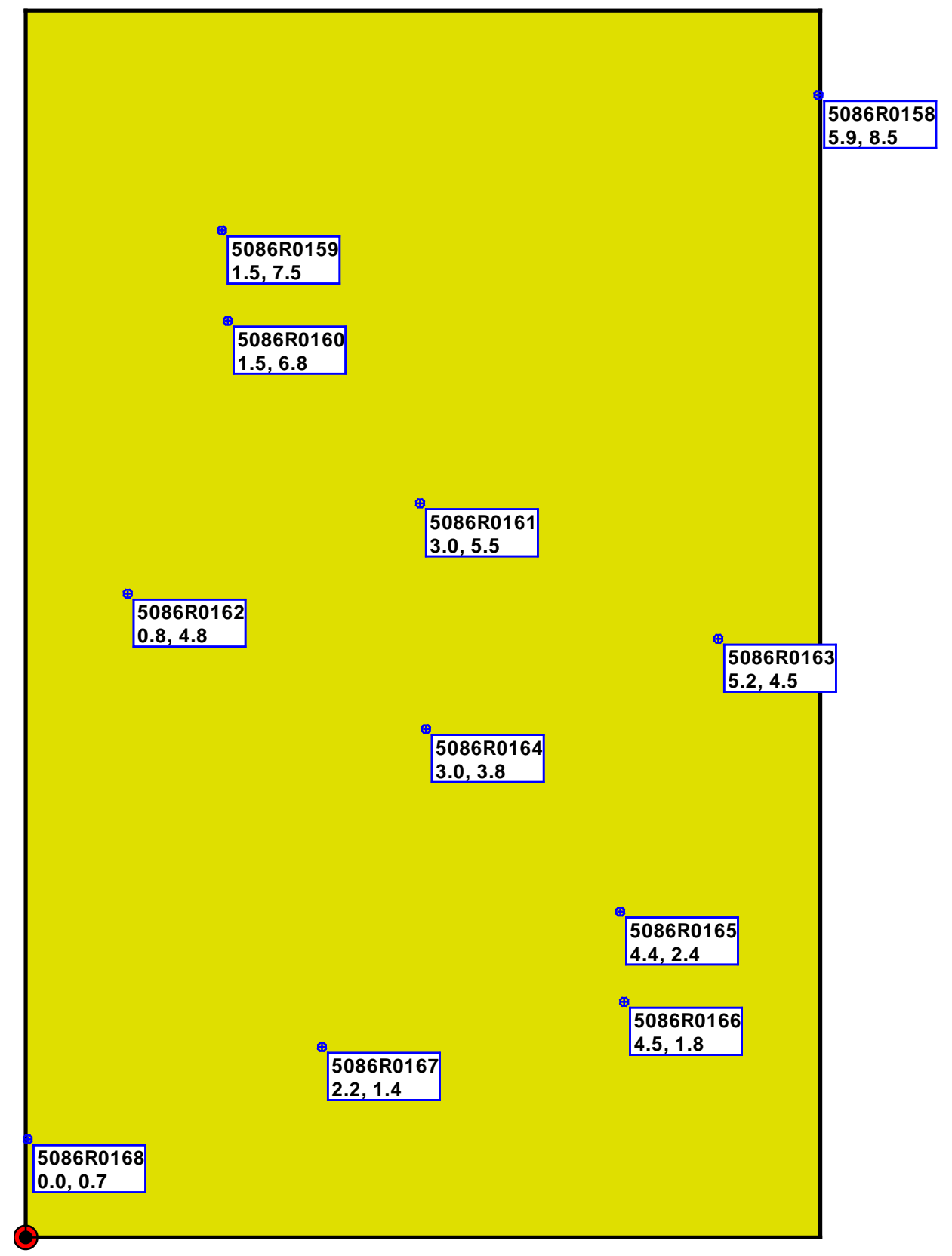

Fig. A-36. Sampling and Direct Measurement Locations for the Building 3543 Slab 


\begin{tabular}{|c|c|c|c|c|c|c|}
\hline \multicolumn{7}{|c|}{$\begin{array}{c}\text { Table A-10. Radionuclide Activities for the } \\
\text { Southeast Laboratory Complex Building } 3543 \text { Slab } \\
\text { Oak Ridge National Laboratory } \\
\text { Oak Ridge, Tennessee }\end{array}$} \\
\hline \multirow{3}{*}{$\begin{array}{l}\text { Measurement } \\
\text { Location/ } \\
\text { Sample ID }\end{array}$} & \multicolumn{4}{|c|}{ Total Activity } & \multirow{2}{*}{\multicolumn{2}{|c|}{$\begin{array}{l}\text { Removable Activity } \\
\text { Gross Alpha \& Beta }\end{array}$}} \\
\hline & \multicolumn{2}{|c|}{ Alpha } & \multicolumn{2}{|c|}{ Alpha-plus-Beta } & & \\
\hline & $\begin{array}{l}\text { Gross } \\
\text { cpm }\end{array}$ & $\begin{array}{c}\text { Activity } \\
\left(\mathrm{dpm} / 100 \mathrm{~cm}^{2}\right)\end{array}$ & $\begin{array}{l}\text { Gross } \\
\text { cpm }\end{array}$ & $\begin{array}{c}\text { Activity } \\
\left(\mathrm{dpm} / 100 \mathrm{~cm}^{2}\right)\end{array}$ & $\begin{array}{c}\text { Alpha } \\
\text { Activity } \\
\left(\mathrm{dpm} / 100 \mathrm{~cm}^{2}\right)\end{array}$ & $\begin{array}{c}\text { Beta } \\
\text { Activity } \\
\left(\mathrm{dpm} / 100 \mathrm{~cm}^{2}\right)\end{array}$ \\
\hline \multicolumn{7}{|c|}{3543 Slab } \\
\hline 5086R0158 & 15 & 98 & 516 & 580 & 0 & 5 \\
\hline 5086R0159 & 38 & 280 & 543 & 660 & 0 & 4 \\
\hline 5086R0160 & 31 & 230 & 582 & 770 & 0 & 0 \\
\hline 5086R0161 & 17 & 110 & 442 & 360 & 0 & 3 \\
\hline 5086R0162 & 22 & 150 & 494 & 510 & 1 & 2 \\
\hline 5086R0163 & 18 & 120 & 552 & 680 & 1 & 1 \\
\hline 5086R0164 & 5 & 16 & 631 & 920 & 0 & 0 \\
\hline 5086R0165 & 27 & 200 & 575 & 750 & 1 & 3 \\
\hline 5086R0166 & 68 & 530 & 797 & 1,400 & 0 & 1 \\
\hline 5086R0167 & 79 & 620 & 792 & 1,400 & 1 & 0 \\
\hline 5086R0168 & 9 & 49 & 517 & 580 & 0 & 0 \\
\hline
\end{tabular}


BUILDING 3592 SLAB 


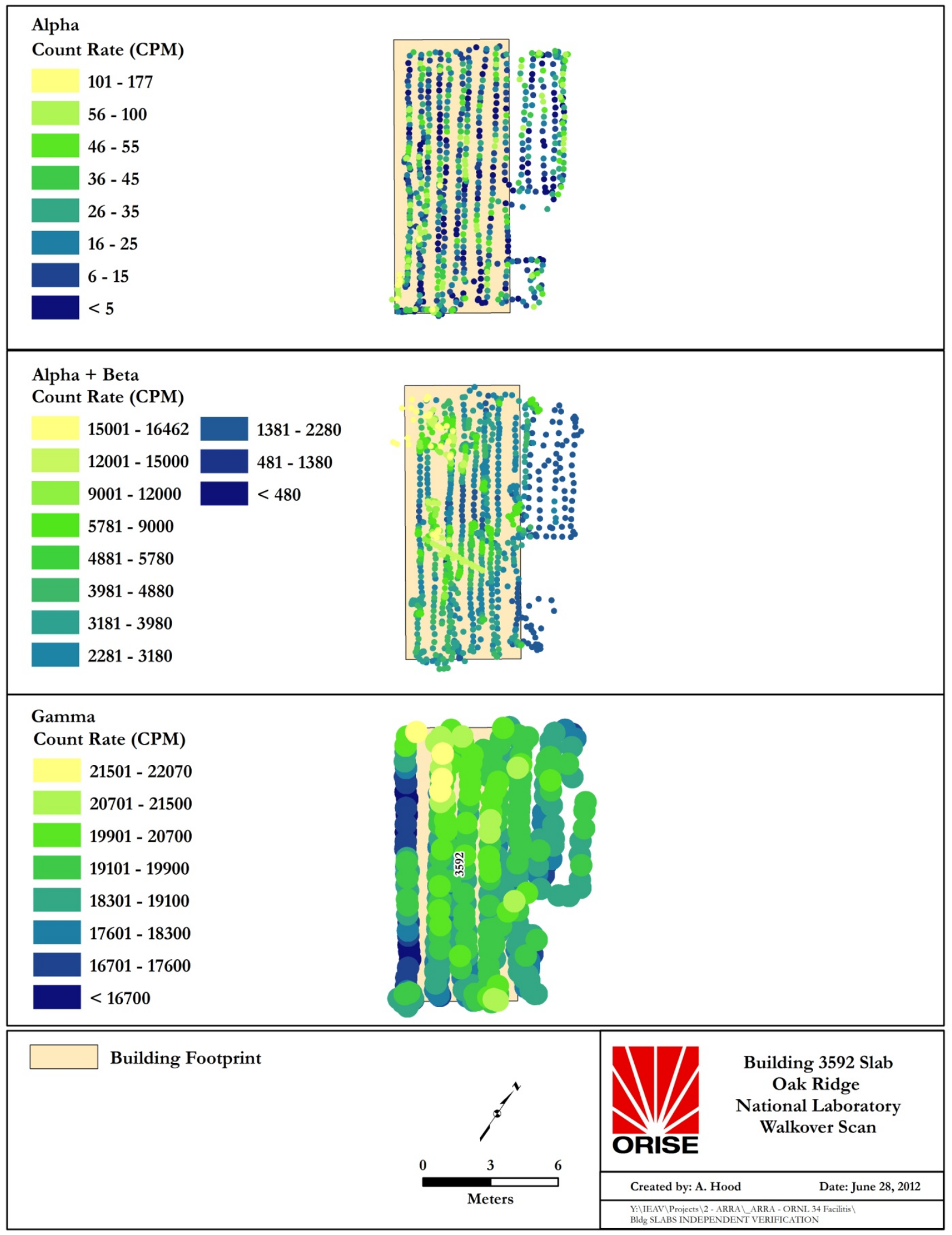

Fig. A-37. Surface Radiation Scans for the Building 3592 Slab 
Building 3592 Slab Alpha and Alpha-plus-Beta Q Plot Summary Statistics for Raw Full Dataset

\begin{tabular}{|c|c|c|c|c|c|c|}
\hline Variable & NumObs & Min & Max & Mean & Median & SD \\
\hline Alpha & 777 & 0 & 177 & 28 & 23 & 25 \\
\hline Alpha-plus-Beta & 1,418 & 0 & 16,462 & 5,759 & 4,296 & 3,785 \\
\hline
\end{tabular}

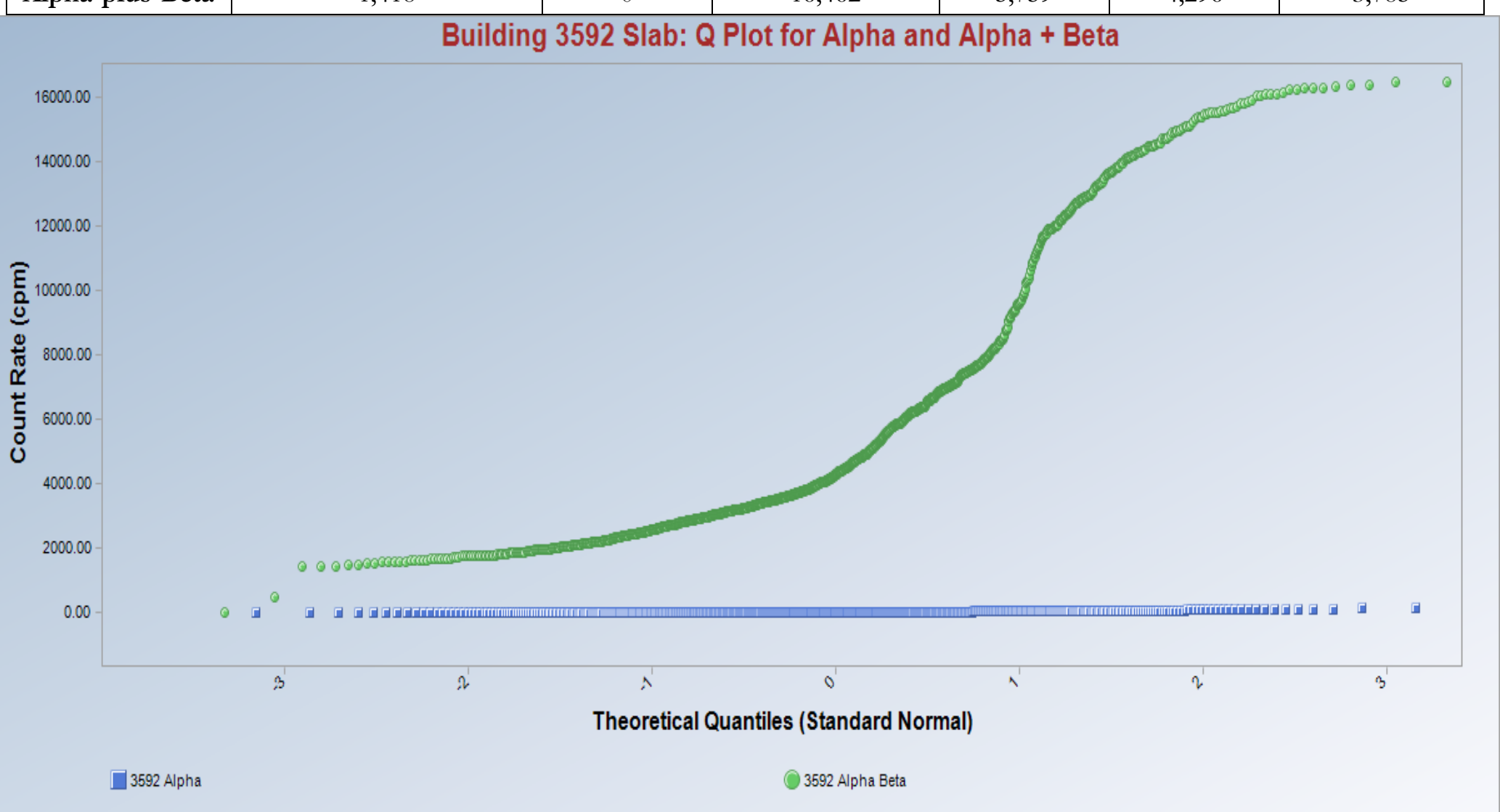

Fig. A-38. Alpha and Alpha-plus-Beta Scan Q-Plot for the Building 3592 Slab 
Building 3592 Slab Gamma Q Plot

Summary Statistics for Raw Full Dataset

\begin{tabular}{|c|c|c|c|c|c|c|}
\hline Variable & NumObs & Min & Max & Mean & Median & SD \\
\hline Gamma & 335 & 16,009 & 22,070 & 18,985 & 19,012 & 1,016 \\
\hline
\end{tabular}

23000.00

22000.00

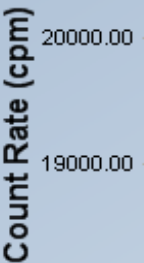

18000.00

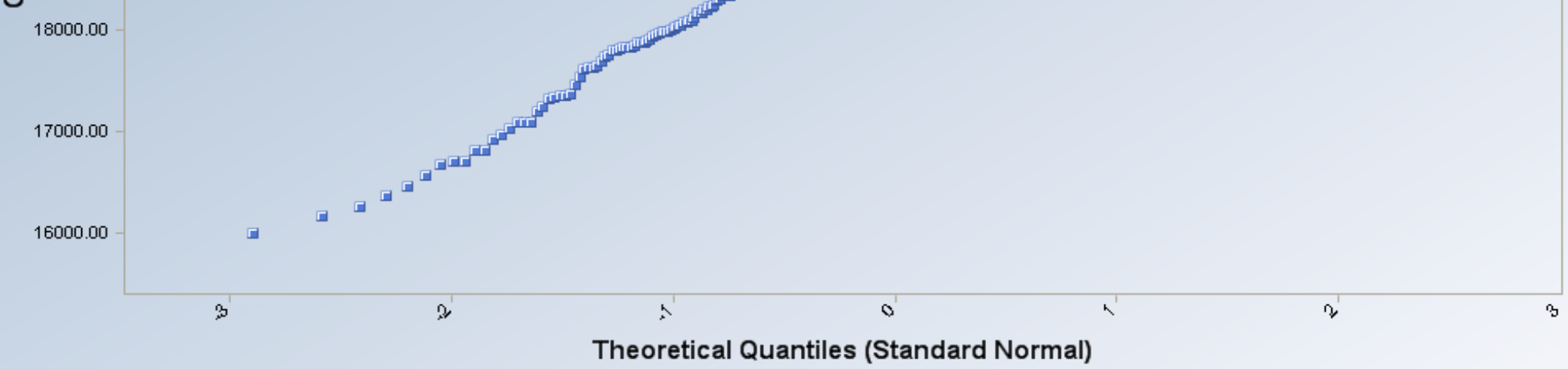

3592 Gamma

Fig. A-39. Gamma Scan Q-Plot for the Building 3592 Slab 


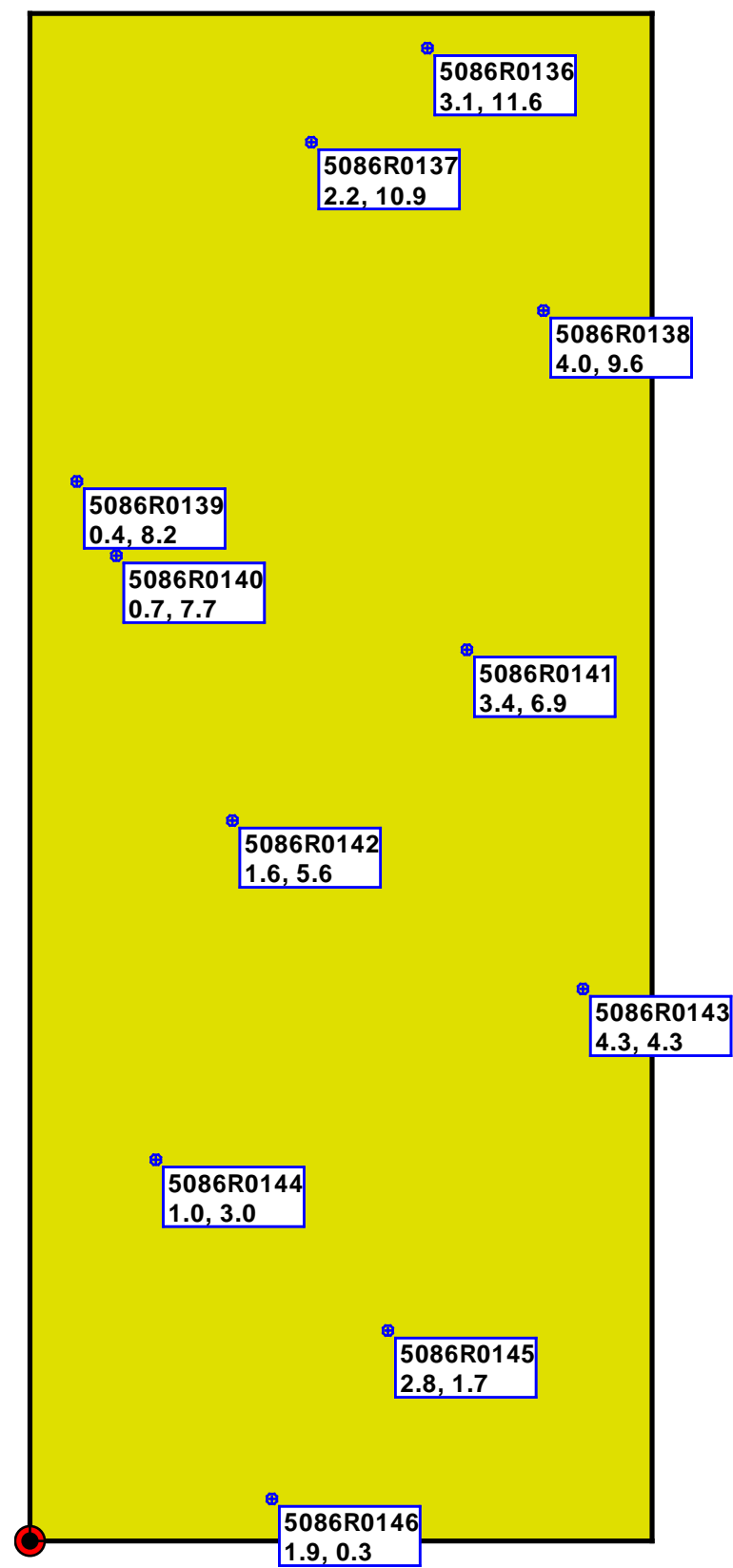

Fig. A-40. Sampling and Direct Measurement Locations for the Building 3592 Slab 


\begin{tabular}{|c|c|c|c|c|c|c|}
\hline \multicolumn{7}{|c|}{$\begin{array}{c}\text { Table A-11. Radionuclide Activities for the } \\
\text { Southeast Laboratory Complex Building } 3592 \text { Slab } \\
\text { Oak Ridge National Laboratory } \\
\text { Oak Ridge, Tennessee }\end{array}$} \\
\hline \multirow{3}{*}{$\begin{array}{c}\text { Measurement } \\
\text { Location/ } \\
\text { Sample ID }\end{array}$} & \multicolumn{4}{|c|}{ Total Activity } & \multirow{2}{*}{\multicolumn{2}{|c|}{$\begin{array}{l}\text { Removable Activity } \\
\text { Gross Alpha \& Beta }\end{array}$}} \\
\hline & \multicolumn{2}{|c|}{ Alpha } & \multicolumn{2}{|c|}{ Alpha-plus-Beta } & & \\
\hline & $\begin{array}{l}\text { Gross } \\
\text { cpm }\end{array}$ & $\begin{array}{c}\text { Activity } \\
\left(\mathrm{dpm} / 100 \mathrm{~cm}^{2}\right)\end{array}$ & $\begin{array}{l}\text { Gross } \\
\text { cpm }\end{array}$ & $\begin{array}{c}\text { Activity } \\
\left(\mathrm{dpm} / 100 \mathrm{~cm}^{2}\right)\end{array}$ & $\begin{array}{c}\text { Alpha } \\
\text { Activity } \\
\left(\mathrm{dpm} / 100 \mathrm{~cm}^{2}\right)\end{array}$ & $\begin{array}{c}\text { Beta } \\
\text { Activity } \\
\left(\mathrm{dpm} / 100 \mathrm{~cm}^{2}\right)\end{array}$ \\
\hline \multicolumn{7}{|c|}{3592 Slab } \\
\hline 5086R0136 & 15 & 98 & 571 & 740 & 0 & 1 \\
\hline 5086R0137 & 13 & 81 & 1,023 & 2,100 & 0 & 0 \\
\hline 5086R0138 & 6 & 24 & 657 & 1,000 & 0 & 0 \\
\hline 5086R0139 & 11 & 65 & 916 & 1,800 & 0 & 5 \\
\hline 5086R0140 & 13 & 81 & 599 & 820 & 0 & 0 \\
\hline 5086R0141 & 9 & 49 & 663 & 1,000 & 1 & 1 \\
\hline 5086R0142 & 7 & 33 & 1,347 & 3,000 & 1 & 3 \\
\hline 5086R0143 & 8 & 41 & 766 & 1,300 & 0 & 1 \\
\hline 5086R0144 & 5 & 16 & 1,714 & 4,100 & 0 & 2 \\
\hline 5086R0145 & 13 & 81 & 1,187 & 2,600 & 1 & 1 \\
\hline 5086R0146 & 2 & -8 & 1,014 & 2,000 & 0 & 1 \\
\hline 5086R0169 & 16 & 110 & 3,861 & 10,000 & 1 & 6 \\
\hline
\end{tabular}


BUILDING 3605 SLAB 


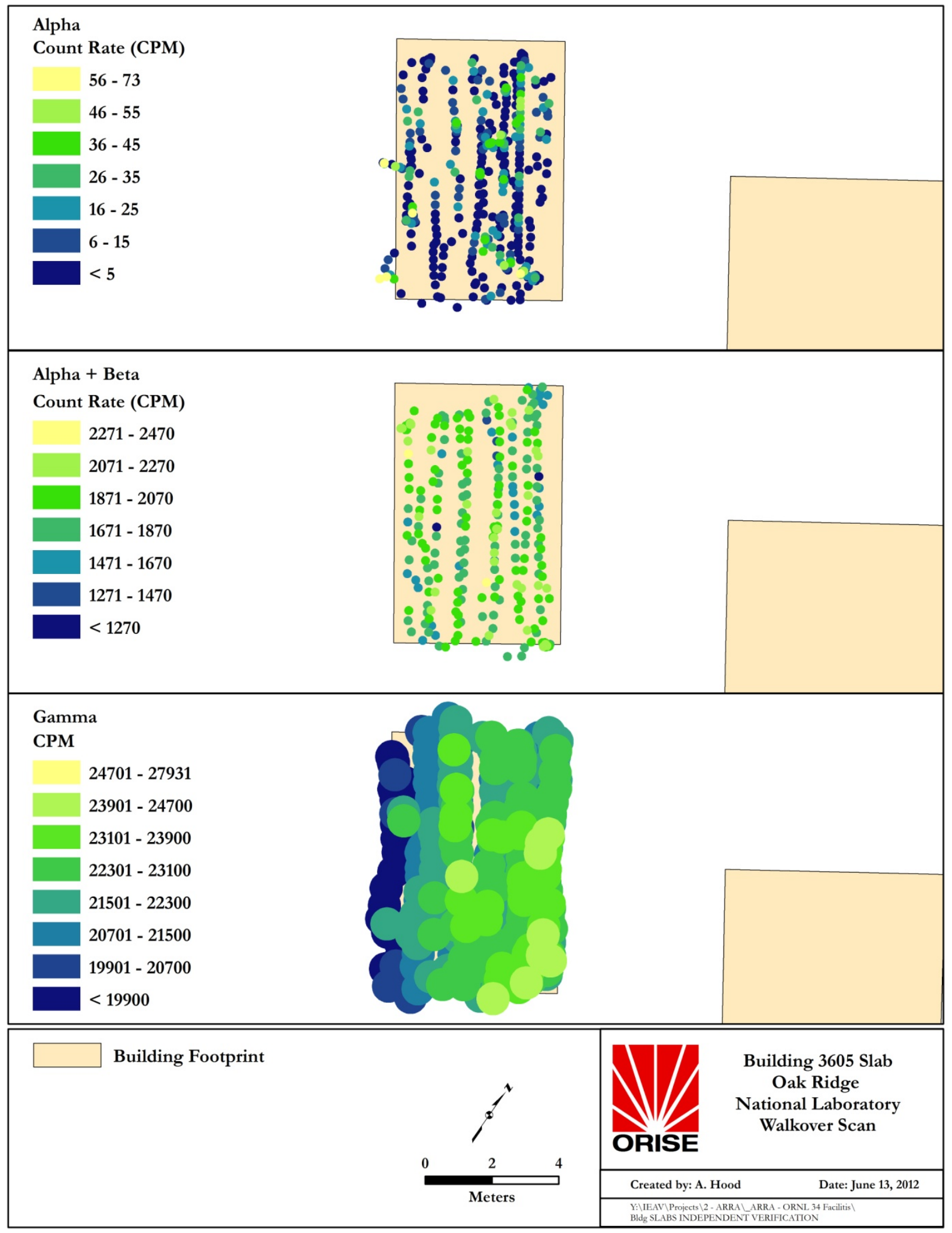

Fig. A-41. Surface Radiation Scans for the Building 3605 Slab 


\begin{tabular}{|c|c|c|c|c|c|c|}
\hline \multicolumn{7}{|c|}{$\begin{array}{c}\text { Building 3605 Slab Alpha and Alpha-plus-Beta Q Plot } \\
\text { Summary Statistics for Raw Full Dataset }\end{array}$} \\
\hline Variable & NumObs & Min & Max & Mean & Median & SD \\
\hline Alpha & 393 & 0 & 73 & 11 & 5 & 14 \\
\hline Alpha-plus-Beta & 278 & 0 & 2,474 & 1,853 & 1,874 & 271 \\
\hline
\end{tabular}

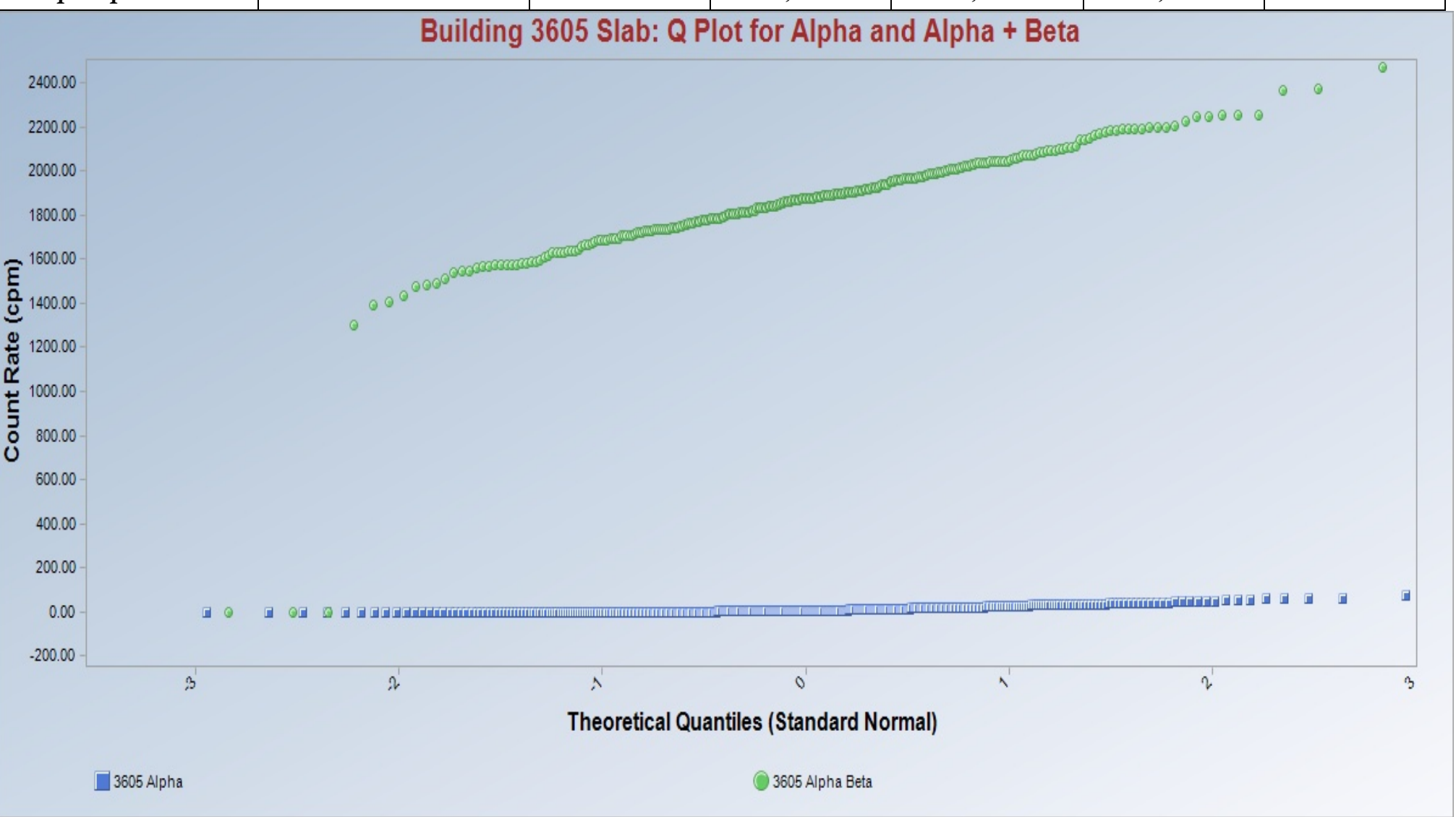

Fig. A-42. Alpha and Alpha-plus-Beta Scan Q-Plot for the Building 3605 Slab 
Building 3605 Slab Gamma Q Plot

Summary Statistics for Raw Full Dataset

\begin{tabular}{|c|c|c|c|c|c|c|}
\hline Variable & NumObs & Min & Max & Mean & Median & SD \\
\hline Gamma & 311 & 18,265 & 27,931 & 22,157 & 22,215 & 1,425 \\
\hline
\end{tabular}

Building 3605 Slab: Q Plot for Gamma

30000.00

29000.00

28000.00

27000.00

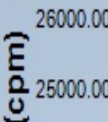

(24000.00

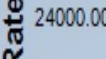

$\stackrel{23000.00}{ }$

穾

○ं 22000.00

21000.00

20000.00

19000.00

18000.00

\605 Gamma

Fig. A-43. Gamma Scan Q-Plot for the Building 3605 Slab 


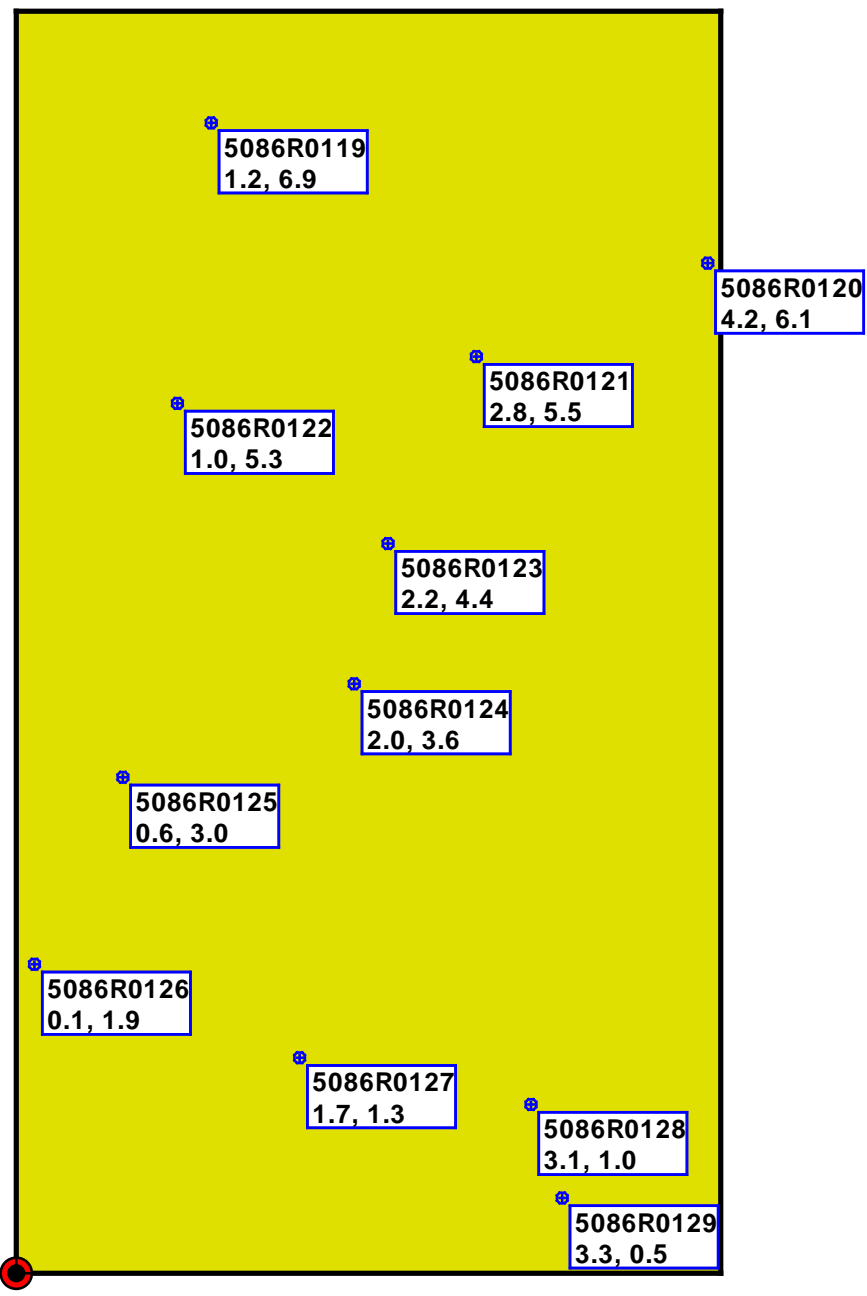

Fig. A-44. Sampling and Direct Measurement Locations for the Building 3605 Slab 


\begin{tabular}{|c|c|c|c|c|c|c|}
\hline \multicolumn{7}{|c|}{$\begin{array}{c}\text { Table A-12. Radionuclide Activities for the } \\
\text { Southeast Laboratory Complex Building } 3605 \text { Slab } \\
\text { Oak Ridge National Laboratory } \\
\text { Oak Ridge, Tennessee }\end{array}$} \\
\hline \multirow{3}{*}{$\begin{array}{c}\text { Measurement } \\
\text { Location/ } \\
\text { Sample ID }\end{array}$} & \multicolumn{4}{|c|}{ Total Activity } & \multirow{2}{*}{\multicolumn{2}{|c|}{$\begin{array}{l}\text { Removable Activity } \\
\text { Gross Alpha \& Beta }\end{array}$}} \\
\hline & \multicolumn{2}{|c|}{ Alpha } & \multicolumn{2}{|c|}{ Alpha-plus-Beta } & & \\
\hline & $\begin{array}{l}\text { Gross } \\
\text { cpm }\end{array}$ & $\begin{array}{c}\text { Activity } \\
\left(\mathrm{dpm} / 100 \mathrm{~cm}^{2}\right)\end{array}$ & $\begin{array}{l}\text { Gross } \\
\text { cpm }\end{array}$ & $\begin{array}{c}\text { Activity } \\
\left(\mathrm{dpm} / 100 \mathrm{~cm}^{2}\right)\end{array}$ & $\begin{array}{c}\text { Alpha } \\
\text { Activity } \\
\left(\mathrm{dpm} / 100 \mathrm{~cm}^{2}\right)\end{array}$ & $\begin{array}{l}\text { Beta Activity } \\
\left(\mathrm{dpm} / 100 \mathrm{~cm}^{2}\right)\end{array}$ \\
\hline \multicolumn{7}{|c|}{3605 Slab } \\
\hline 5086R0119 & 10 & 57 & 493 & 510 & 0 & 0 \\
\hline 5086R0120 & 7 & 33 & 527 & 610 & 0 & 2 \\
\hline 5086R0121 & 7 & 33 & 548 & 670 & 0 & 1 \\
\hline 5086R0122 & 7 & 33 & 499 & 530 & 1 & 4 \\
\hline 5086R0123 & 9 & 49 & 517 & 580 & 0 & 1 \\
\hline 5086R0124 & 7 & 33 & 532 & 630 & 0 & 0 \\
\hline 5086R0125 & 2 & -8 & 488 & 500 & 1 & 3 \\
\hline 5086R0126 & 8 & 41 & 507 & 550 & 0 & 2 \\
\hline 5086R0127 & 9 & 49 & 577 & 760 & 0 & 3 \\
\hline 5086R0128 & 6 & 24 & 565 & 720 & 0 & 1 \\
\hline 5086R0129 & 5 & 16 & 531 & 620 & 0 & 1 \\
\hline
\end{tabular}




\section{APPENDIX B \\ MAJOR INSTRUMENTATION}




\section{B.1 SCANNING AND MEASUREMENT INSTRUMENT/DETECTOR COMBINATIONS}

\section{B.1.1 AlPHA-PLUS-BETA}

Ludlum Floor Monitor Model 239-1

combined with

Ludlum Ratemeter-Scaler Model 2221

coupled to Ludlum Gas Proportional Detector Model 43-37, Physical Area: $550 \mathrm{~cm}^{2}$

(Ludlum Measurements, Inc., Sweetwater, TX)

\section{B.1.2 GAMMA}

Ludlum NaI Scintillation Detector Model 44-10, Crystal: $5.1 \mathrm{~cm}$ x $5.1 \mathrm{~cm}$

(Ludlum Measurements, Inc., Sweetwater, TX)

coupled to:

Ludlum Ratemeter-Scaler Model 2221

(Ludlum Measurements, Inc., Sweetwater, TX)

\section{B.2 DIRECT MEASUREMENT INSTRUMENT/DETECTOR COMBINATIONS}

\section{B.2.1 AlPHA AND BETA}

Ludlum Ratemeter-Scaler Model 2221

coupled to

Ludlum Gas Proportional Detector Model 43-68, Physical Area: $126 \mathrm{~cm}^{2}$

(Ludlum Measurements, Inc., Sweetwater, TX)

\section{B.3 LABORATORY ANALYTICAL INSTRUMENTATION}

Low background alpha/beta counting system

Canberra/Tennelec LB5100W Eclipse Software

(Canberra, Inc., Meriden, CT) 


\section{APPENDIX C \\ SURVEY AND ANALYTICAL PROCEDURES}




\section{C.1 PROJECT HEALTH AND SAFETY}

Survey activities were conducted in accordance with the ORAU/ORISE overall health and safety program (HASP) and radiological protection program manuals. Pre-survey activities included an overview of potential health and safety issues. Potential health and safety issues that were identified were appropriately addressed by the ORAU/ORISE HASP, site-specific Integrated Safety Management (ISM) pre-job hazard checklist, and an activity hazard analysis (AHA) prior to beginning site work.

\section{C.2 QUALITY ASSURANCE}

Analytical and field survey activities were conducted in accordance with procedures from the following ORAU and ORISE documents:

- Survey Procedures Manual (ORISE 2012a)

- Laboratory Procedures Manual (ORISE 2012b)

- Quality Program Manual (ORAU 2012)

The procedures contained in these manuals were developed to meet the requirements of 10 CFR 830 Subpart A, Quality Assurance Requirements, Department of Energy Order 414.1C, Quality Assurance, and the U.S. Nuclear Regulatory Commission, Quality Assurance Manual for the Office of Nuclear Material Safety and Safeguards, and contain measures to assess processes during their performance.

Quality control procedures include:

- Daily instrument background and check-source measurements to confirm that equipment operation is within acceptable statistical fluctuations

- Participation in Mixed Analyte Performance Evaluation Program (MAPEP), National Institute for Standards and Technology (NIST) Radiochemistry Intercomparison Program (NRIP), and Intercomparison Testing Program (ITP) Laboratory Quality Assurance Programs

- Training and certification of all individuals performing procedures

- Periodic internal and external audits 


\section{C.3 CALIBRATION}

Detectors used for assessing surface activity were calibrated in accordance with ISO-7503 ${ }^{1}$ recommendations. Total alpha and beta efficiencies $\left(\boldsymbol{\varepsilon}_{\text {total }}\right)$ were determined for each instrument/detector combination and consisted of the product of the $2 \pi$ instrument efficiency $\left(\varepsilon_{i}\right)$ and surface efficiency $\left(\varepsilon_{\mathrm{s}}\right): \varepsilon_{\mathrm{total}}=\varepsilon_{\mathrm{i}} \times \varepsilon_{\mathrm{s}}$. Beta total efficiencies were determined based on a beta energy multi-point calibration, development of instrument efficiency to beta energy calibration curves, and the calculation of the weighted efficiency representing the Th-232 decay series. Included in the weighted efficiency was an empirically determined correction for disequilibrium in the decay series that results from $\mathrm{Rn}-220$ loss. A $3.8 \mathrm{mg} / \mathrm{cm}^{2}$ density thickness mylar window was used on the beta detectors to block detector response contributions from alpha radiation.

Th-230 was selected as the alpha calibration source. The $2 \pi$ alpha instrument efficiency $\left(\varepsilon_{i}\right)$ factor was 0.39 for the gas proportional detector. C-14, Tc-99, Tl-204, and Sr/Y-90 were selected as the beta calibration sources to represent the energy distribution of the detectable beta-emitters in the Th-232 decay series. The $2 \pi$ interpolated $\varepsilon_{\mathrm{i}}$ factors for the detectable beta-emitters ranged from 0.34 to 0.56 for the gas proportional detector. ISO-7503 recommends an $\varepsilon_{\mathrm{s}}$ of 0.25 for alpha emitters and beta emitters with a maximum energy of less than $0.4 \mathrm{MeV}$, and an $\varepsilon_{\mathrm{s}}$ of 0.5 for maximum beta energies greater than $0.4 \mathrm{MeV}$. The thorium series alpha efficiency is 0.10 . The total weighted beta efficiency for the beta detectors ranged from 0.08 to 0.28 .

Calibration of all field and laboratory instrumentation was based on standards/sources, traceable to NIST, when such standards/sources were available. In cases where they were not available, standards of an industry-recognized organization were used.

\section{C.4 SURVEY PROCEDURES}

\section{C.4.1 SURFACE SCANS}

Scans for elevated gamma radiation were performed by passing the detector slowly over the surface, the distance between the detector and the surface was maintained at a minimum-nominally about $1 \mathrm{~cm}$ or as close to the surface as possible. A NaI scintillation detector was used to scan for elevated

${ }^{1}$ International Standard. ISO 7503-1, Evaluation of Surface Contamination - Part 1: Beta-emitters (maximum beta energy greater than $0.15 \mathrm{MeV}$ ) and alpha-emitters. August 1, 1988. 
gamma radiation throughout the slab. The scan minimum detectable concentrations (MDCs) for the $\mathrm{NaI}$ scintillation detector for the contaminants of concern for a concrete surface were obtained directly from NUREG-1507², when available, or estimated using the calculation approach described in NUREG-1507. A typical NaI 2-in × 2-in detector MDC is $6.4 \mathrm{pCi} / \mathrm{g}$ for cesium-137. Audible increases in the activity rate are investigated by ORAU. It is standard procedure for ORAU staff to pause and investigate any locations where gamma radiation is distinguishable from background levels.

\section{C.4.2 Surface ACTIVITY MEASUREMENTS}

Measurements of total alpha and total beta surface activity levels were performed using hand-held scintillation detectors coupled to portable ratemeter-scalers. Count rates (cpm), which were integrated over one minute with the detector held in a static position, were converted to activity levels $\left(\mathrm{dpm} / 100 \mathrm{~cm}^{2}\right)$ by dividing the count rate by the total static efficiency $\left(\varepsilon_{\mathrm{i}} \times \varepsilon_{\mathrm{s}}\right)$ and correcting for the physical area of the detector.

The a priori $\mathrm{MDC}$ for surface activity measurements was calculated using the following equation:

Where:

$$
M D C=\frac{3+(4.65 \sqrt{B)}}{T x \varepsilon_{\text {Tot }} x G}
$$

$\begin{array}{lll}\mathrm{B} & = & \text { background (total counts) in time interval, } \mathrm{T} \\ \mathrm{T} & = & \text { count time (min) used for field instruments } \\ \varepsilon_{\mathrm{Tot}} & = & \text { total efficiency }=\varepsilon_{\mathrm{i}} \times \varepsilon_{\mathrm{s}} \\ \varepsilon_{\mathrm{i}} & = & \text { instrument efficiency } \\ \varepsilon_{\mathrm{s}} & = & \text { source efficiency } \\ \mathrm{G} & = & \left.\text { geometry (physical detector area } \mathrm{cm}^{2} / 100\right)\end{array}$

The a priori alpha static MDC was approximately $76 \mathrm{dpm} / 100 \mathrm{~cm}^{2}$ using the total efficiency of 0.10 and an instrument background of $2 \mathrm{cpm}$. The physical surface area assessed by the scintillation detector used was $100 \mathrm{~cm}^{2}$. The a priori beta static MDC was approximately $280 \mathrm{dpm} / 100 \mathrm{~cm}^{2}$ using the total efficiency of 0.27 and the nominal instrument background of $400 \mathrm{cpm}$. The physical surface area assessed by the detector used was $126 \mathrm{~cm}^{2}$.

${ }^{2}$ NUREG-1507. Minimum Detectable Concentrations With Typical Radiation Survey Instruments for V arious Contaminants and Field Conditions. U.S. Nuclear Regulatory Commission. Washington, DC; June 1998. 


\section{C.4.3 Removable ACtivity Measurements}

Smear samples for removable gross alpha and gross beta contamination were obtained from each measurement location. Removable activity samples were collected using numbered filter paper disks, $47 \mathrm{~mm}$ in diameter. Moderate pressure was applied to the smear and approximately $100 \mathrm{~cm}^{2}$ of the surface was wiped. Smears were placed in labeled envelopes with the location and other pertinent information recorded.

\section{C.5 RADIOLOGICAL ANALYSIS}

\section{C.5.1 Gross AlPHA/BETA}

Smears were counted on a low-background gas proportional system for gross alpha and beta activity. The MDCs of the procedure were $12.5 \mathrm{dpm} / 100 \mathrm{~cm}^{2}$ and $12.8 \mathrm{dpm} / 100 \mathrm{~cm}^{2}$ for a 2-minute count time for gross alpha and gross beta, respectively.

\section{C.5.2 Detection Limits}

Detection limits, referred to as MDC, were based on 3 plus 4.65 times the standard deviation of the background $(\mathrm{BKG})$ count $\left[3+\left(4.65(\mathrm{BKG})^{1 / 2}\right)\right]$. Because of variations in background levels, measurement efficiencies, and contributions from other radionuclides in samples, the detection limits differ from sample to sample and instrument to instrument. 